UNIVERSIDADE DE SÃO PAULO

INSTITUTO DE GEOCIEENCIAS

\title{
QUALIDADE DA ÁGUA E USO DO SOLO NA BACIA DO RIBEIRÃO SERRA AZUL (MG)
}

\author{
Elexander Amaral de Souza
}

Orientador: Prof. Dr. Arlei Benedito Macedo

\section{DISSERTAÇÃO DE MESTRADO}

Programa de Pós-Graduação em Recursos Minerais e Hidrogeologia 


\section{ERRATA}

\section{Dissertação: QUALIDADE DA ÁGUA E USO DO SOLO NA BACIA DO RIBEIRÃO SERRA AZUL}

Elexander Amaral de Souza

Universidade de São Paulo

Instituto de Geociências

Dep. Geologia Sedimentar e Ambiental

07/05/2003

1. Na página 23 , linha 4, onde se lê: “...no comércio da bem...”, leia-se: “...no comércio do bem..."

2. Na página 69, linha 4, onde se lê: "Além de criar...", leia-se "Além de criarem...".

3. Acrescentar à Bibliografia: Meybeck, Michel (1989), Global freshwater quality :a first assessment. Oxford, Inglaterra, $306 \mathrm{p}$.

4. Acrescentar à Bibliografia: Christofoletti, Antonio, 1980. Geomorfologia, São Paulo, Blucher, 149p.

5. Na página 68 , linha 1, onde se lê: "Considerando que as transgressões...", leia-se "Considerando que as não-conformidades..."

6. Na página 67 , linha 24 , onde se lê: “... quanto ao percentual de transgressão ...”, leia-se "... quanto ao percentual de superação ..."

7. Na página 33 , linha 7, onde se lê: "...os valores ficam em torno de $10 \mathrm{mg} / 1 \mathrm{O}_{2}$." , leia-se "...os valores ficam em torno ou maiores que $10 \mathrm{mg} / 1 \mathrm{O}_{2}$, UNESCO/WHO/UNEP (1992)."

8. Na página 33, linha 8, onde se lê: “...nos esgotos crus...”, leia-se “...nos esgotos brutos..."

9. Na página 31 , linha 11 , onde se lê: "Sem formarem uma rede,...", leia-se "Sem formarem uma rede significativa,..."

10. Na página 10 , linha 25 , onde se lê: “... durante a segunda metade do séc. XIX,...", leiase "durante a segunda metade do séc. XVIII, ..." 


\title{
UNIVERSIDADE DE SÃO PAULO INSTITUTO DE GEOCIÊNCIAS
}

\section{QUALIDADE DA ÁGUA E USO DO SOLO NA BACIA DO RIBEIRÃO SERRA AZUL (MG)}

\author{
ELEXANDER AMARAL DE SOUZA
}

Orientador: Prof. Dr. Arlei Benedito Macedo

DISSERTAÇÃO DE MESTRADO

COMISSÃO JULGADORA

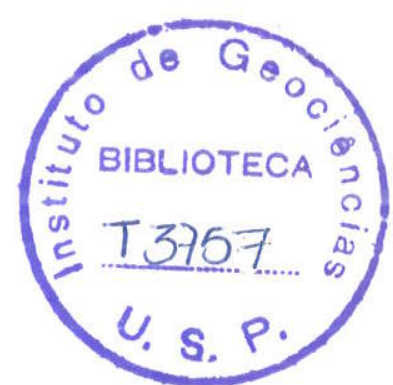

Assinatura

Nome

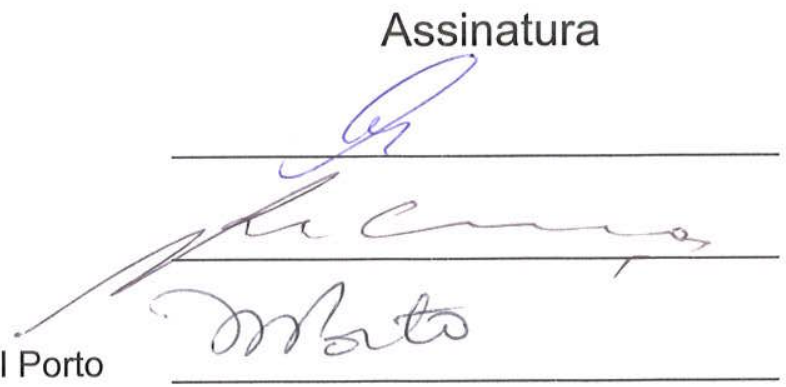

Prof $^{\text {a. }} \quad$ Dr $^{\mathrm{a}}$ Mônica Ferreira do Amaral Porto

SÃO PAULO

2003 


\section{UNIVERSIDADE DE SÃO PAULO \\ INSTITUTO DE GEOCIÊNCIAS \\ DEPARTAMENTO DE GEOLOGIA SEDIMENTAR E AMBIENTAL \\ PROGRAMA DE PÓS-GRADUAÇÃO EM RECURSOS \\ MINERAIS E HIDROGEOLOGIA}

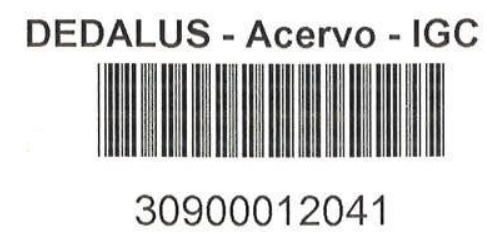

QUALIDADE DA ÁGUA E USO DO SOLO NA BACIA DO RIBEIRÃO SERRA AZUL (MG)

Elexander Amaral de Souza

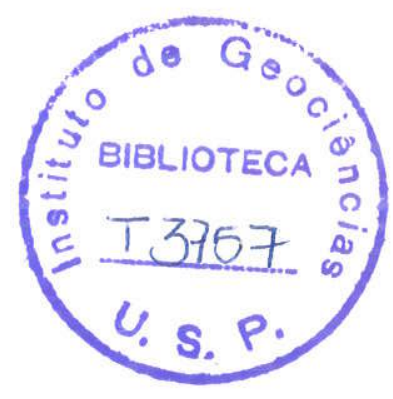

Dissertação apresentada ao Programa de Pós-Graduação em Recursos Minerais e Hidrogeologia, do Departamento de Geologia Sedimentar e Ambiental do Instituto de

Geociências da Universidade de São Paulo, para obtenção do título de Mestre em Ciências.

Orientador: Prof. Dr. Arlei Benedito Macedo 
Agradecimentos

Agradeço à CAPES, Instituto de Geociências, Coordenadoria de Serviço e Assistência Social (COSEAS/USP), pelo apoio e bolsas recebidas.

Agradeço à minha família, principalmente minha mãe, Eunice.

Agradeço ao Prof. Arlei e suas orientações.

Agradeço à COPASA/MG e a Tales Teodoro, pelo apoio recebido.

Agradeço especialmente às figuras: Ademir, Liliana, Márcia, Tatiane, Eri, Ney, e à Neide, Sérgio, Martiniana, Sidney e Sílvia, pelo apoio e incentivo fundamentais. 
Índice, 4.

Índice das Tabelas, 5.

Índice de Figuras, 5.

Índice de Quadros, 5.

Índice de Gráficos, 5.

Índice de Abreviações, 6 .

Índice de Anexos, 6.

Resumo, 7.

Abstract, 7.

Introdução, 8.

Capítulo I, 13.

Capítulo II, 25.

Capítulo III, 37.

Capítulo IV, 42.

Conclusão, 66.

Referências Bibliográficas, 70.

Anexos, 73. 


\section{ÍNDICE}

1. Introdução, 8.

1.J Desenvolvimento sustentável, 8 .

I.2 Ocupação do solo e recursos hídricos, 10.

1.3. Justificativa e Objetivos, 11 .

2. A Bacia Hidrográfica do Ribeirão Serra Azul, 13.

2.1 Geomorfologia, 13.

2.2 Geologia, 16.

2.3 Clima, 17.

2.4 Sócio-Economia, 21.

3. Qualidade da Água, 25.

3.1 Conceitos, 25.

3.2 Gerenciamento, 25.

3.3 Enquadramento, 26.

3.4 Impactos prováveis, 27.

3.5 Monitoramento, 31.

3.6 Descrição sumária das variáveis de QA, 32 .

4. Uso do Solo, 37.

4.1 Ano 1977, 37.

4.2 Ano 1989, 38 .

5. Análises pertinentes, 42.

5.1 Drenagem e Geologia, 42.

5.2 O uso do solo: 1977 e 1989, 44.

5.3 O uso do solo: $1999,46$.

5.4 Evolução do uso do solo, 48.

5.5 Dinâmica da qualidade da água, 49.

5.5.1 Coliformes, 53.

5.5.2 Cor, 54.

5.5.3 DBO, 55.

5.5.4 Ferro, 56.

5.5.5 Manganês total, 57.

5.5.6 Nitrato, 58 .

5.5.7 Nitrito, 58 .

5.5.8 Oxigênio Dissolvido, 59.

5.5.9 Fósforo total, 60.

$5.5 .10 \mathrm{pH}, 61$.

5.5.11 Turbidez, 61 .

5.5.12 Sólidos em Suspensão, 62.

5.6 Variação da qualidade da água e do uso do solo, 63.

6. Conclusão, 66.

Referências Bibliográficas, 70.

Anexos, 73. 


\section{Tabelas}

Tabela 1 - A percepção do meio ambiente x economia.

Tabela 2 - Empreendimentos de escala industrial presentes ao longo da história da bacia Serra Azul.

Tabela 3 - Características morfométricas das sub-bacias.

Tabela 4 - Uso do solo em 1999.

Tabela 5 - Uso do solo em 1999: agrupado.

Tabela 6 - Taxa de variação do uso do solo.

Tabela 7 - Relação entre a evolução das variáveis de qualidade da água e eventos climáticos e do uso do solo.

Tabela 8 - Produção sólida para as sub-bacias em $\mathrm{kg} / \mathrm{ha} / \mathrm{ano}$.

Tabela 9 - Inferência estatística: percentual de amostras em não-conformidade com a Classe 1 durante o semestre úmido.

\section{FIGURAS}

Figura 0 - Esquema geral da pesquisa.

Figura 1 - Localização da Bacia do Ribeirão Serra Azul: No país, no Estado de Minas Gerais, na Região Metropolitana de Belo Horizonte (RMBH), e nos municípios.

Figura 2 - Bacia do Ribeirão Serra Azul.

Figura 3 - Litoestratigrafia simplificada da Bacia do Ribeirão Serra Azul.

Figura 4 - Uso do solo na Bacia do Ribeirão Serra Azul.

Figura 5 - Composição RGB

\section{QUADROS}

Quadro 1 - Coluna Litoestratigráfica Simplificada

Quadro 2 - Recursos financeiros envolvidos na mineração local

Quadro 3 - QA para a Classe 1: Extrato da Deliberação COPAM 10/86.

Quadro 4 - Padrões de potabilidade para algumas variáveis de QA. CETESB (1990).

Quadro 5 - Nível de importância de determinadas variáveis para a avaliação da

poluição não-industrial na qualidade da água:

Quadro 6 - Métodos para a determinação da QA, COPASA.

Quadro 7 - Resumo do uso do solo na bacia Serra Azul em 1977.

Quadro 8 - Resumo do uso do solo na bacia Serra Azul em 1989.

Quadro 9 - Resumo agrupado do uso do solo de 1977 e 1989

Quadro 10 - Uso do solo 1977 e 1989: correção da área.

Quadro 11 - Produção média obtida nos Estados Unidos para a produção em kg/ha/ano, de fósforo e nitrogênio.

\section{GRÁTICOS}

Gráfico 1 -- Temperatura mediana, estação Fazenda Cavalo.

Gráfico 2-Precipitação Mediana - Fazenda Cavalo.

Gráfico 3 - Precipitação mediana (jan-mar).

Gráfico 4 - Precipitação total, estação Fazenda Cavalo (abr-mar)

Gráfico 5 - Precipitação total, estação Fazenda Cavalo (jan-dez)

Gráfico 6-Populações de Igarapé e Mateus Leme.

Gráfico 7 -Produção de hortifrutíferos. 
Gráfico 8-Compensação financeira devida a exploração mineral. Fonte: DNPM

Gráficos 9 - Características morfométricas das sub-bacias.

Gráfico10 - Percentual de ocupação dos grupos de uso do solo em 1977.

Gráfico 11 - Percentual de ocupação dos grupos de uso do solo em 1989

Gráfico 12 - Percentual de ocupação dos grupos de uso do solo em 1999.

Gráfico 13 - Percentual de ocupação dos grupos de uso do solo em Serra Azul a) 1977; b) 1989 ; c) 1999 .

Gráfico 14 - Percentual de ocupação dos grupos de uso do solo em Jacu. a) 1977; b) $1989 ;$ c) 1999.

Gráfico 15 - Percentual de ocupação dos grupos de uso do solo em Estiva. a) 1977; b) $1989 ;$ c) 1999.

Gráfíco 16 - Percentual de ocupação dos grupos de uso do solo en Diogo. a) 1977; b) $1989 ; \mathbf{c}) 1999$.

Gráfico 17 - Percentual de ocupação dos grupos de uso do solo em Potreiro. a) 1977; b) $1989 ; \mathbf{c}) 1999$.

Gráfico 18 - Percentual de ocupação dos grupos de uso do solo em Curralinho. a) 1977; b) 1989 ; c) 1999 .

Gráfico 19 - Vazão mensal mediana: Serra Azul e Diogo.

\section{DESCRIÇÃO DAS ABREVIAÇÕES}

(CEASA-MG) - Central de Abastecimento S/A

(CONAMA) - Conselho Nacional do Meio Ambiente

(COPAM-MG) - Conselho Estadual de Política Ambiental

(COPASA) - Cia. de Saneamento de Minas Gerais

(DBO) - Demanda Bioquímicá de Oxigênio

(DNPM) - Departamento Nacional da Produção Mineral

(IGA) - Instituto de Geociências Aplicadas de Minas Gerais

(INPE) - Instituto Nacional de Pesquisas Espaciais

(OD) - Oxigênio Dissolvido

(PNMA) - Política Nacional de Meio Ambiente

(PNRH) - Plano Nacional de Recursos Hídricos

(QA) - Qualidade da Água

(RMBH) - Região Metropolitana de Belo Horizonte

(SDT) - Sólidos Dissolvidos Totais

(SS) - Sólidos em Suspensão

(SSA) - Sistema Serra Azul

\section{ANEXOS}

Anexo 1 - Dados sobre temperatura e pluviometria - Estação Climatológica Fazenda Cavalo - COPASA.

Anexo 2 - Dados brutos de Qualidade da Água nas sub-bacias.

Anexo 3 - Dados brutos das vazóes mensais de Diogo e Serra Azul.

Anexo 4 - Quadros resumo das inferências estatísticas para as diversas variáveis de qualidade da água. 


\section{Resumo}

A bacia hidrográfica do ribeirão Serra Azul se localiza na Região Metropolitana de Belo Horizonte e abastece cerca de 500 mil habitantes. Suas principais atividades econômicas são a agricultura e a mineração. Através dos dados de monitoramento mensal, foi analisada a dinâmica dos parâmetros fixados para a Classe 1 na resolução CONAMA 20/86, em relação ao ciclo hidrológico e ao uso do solo. Em geral, tem havido na bacia a expansão da agropecuária e urbanização, em detrimento da vegetação nativa. Excetuando-se a sub-bacia do Potreiro, constatou-se que a taxa de uso do solo tem diminuído com o tempo nas demais sub-bacias. Durante o período de chuvas, as fontes de poluentes, principalmente difusas, fizeram dos Coliformes, Ferro total e solúvel, Cor, Manganês total e Fósforo total, os principais casos de não-conformidade. Não foi possível estabelecer uma relação entre as variações do clima e do uso do solo para as variáveis DBO, pH, Nitrito e Ferro solúvel.

\section{Abstract}

The Serra Azul watershed is located in the Metropolitan Area of Belo Horizonte and it supplies around 500 thousand inhabitants. Its main economical activities are agriculture and mining. Through the water quality monthly monitoring data, the dynamics of the variables listed in the Class 1 of the CONAMA 20/86 Resolution, has been analyzed in relation to the hydrological cycle and to the land use. The diffuse sources of pollution, during the rainy period, made Coliformes, Total and Soluble Iron, Color, Total Manganese and Total Phosphorus, the main cases of no-conformity.

It has not been possible to establish a qualitative relationship between the evolution of the land use and DBO, pH, Nitrite and Soluble Iron variables.

\section{PALAVRAS-CHAVE/KEY WORDS (5)}

Qualidade da Água, Uso do Solo, Resolução CONAMA 20/86, Recursos Hídricos, Gestão Ambiental.

Water quality, Land use, 20/86 CONAMA Resolution, Water Resources, Environmetal Management. 


\section{Introdução}

\section{I Desenvolvimento sustentável}

A população mundial vive o seguinte antagonismo: melhora das condições de vida e piora da qualidade ambiental. A deterioração do meio ambiente coloca em risco a vida de outras gerações e se manifesta de maneira desigual, já que substancial melhoria de vida pode ser atribuída às pessoas dos países desenvolvidos e que, conseqüentemente, poluem muito mais o planeta. Não obstante, o sistema de produção capitalista força os países pobres a obedecerem às normas dos mais ricos, que por sua vez, já usaram grande parte dos recursos naturais do planeta, favorecendo para a manutenção do atual quadro de desigualdade e de degradação entre as nações.

A compreensão da dinâmica ecologia $x$ economia evoluiu de uma idéia de recursos naturais inesgotáveis para a da possibilidade de escassez e racionamento. Baseando-se em Viola (1991), a Tabela 1 resumiria essas percepções.

\begin{tabular}{|c|c|c|c|}
\hline Período & Tema & No mundo & No Brasil \\
\hline 60 's & $\begin{array}{l}\text { Início do } \\
\text { ambientalismo }\end{array}$ & $\begin{array}{l}\text { Surgem as primeiras instituições } \\
\text { ambientais: agencias de proteção, } \\
\text { ONG's e grupos de pesquisas. } \\
\text { Ação restrita principalmente aos } \\
\text { EUA. }\end{array}$ & $\ldots$ \\
\hline $70 \mathrm{~s}$ & $\begin{array}{l}\text { Consensos } \\
\text { globais }\end{array}$ & $\begin{array}{l}\text { Clube de Roma: limite de } \\
\text { crescimento para economias e } \\
\text { populações; Conferência de } \\
\text { Estocolmo: prevê mecanismos de } \\
\text { proteção ambiental e controle } \\
\text { demográfico. O ambientalismo se } \\
\text { enraíza: Canadá, Nova Zelândia, } \\
\text { Japão e Alemanha. }\end{array}$ & $\begin{array}{l}\text { O governo não reconhece a } \\
\text { importância do controle populacional } \\
\text { e da degradação ambiental: início da } \\
\text { imagem de descaso do Brasil. Surge } \\
\text { a primeira entidade ambiental: } \\
\text { AGAPAN, em } 1973 \text { em Porto } \\
\text { Alegre, se atendo a assuntos como } \\
\text { Sete Quedas e Amazonia. }\end{array}$ \\
\hline $80 \mathrm{~s}$ & Boom Consciente & $\begin{array}{l}\text { Devido à crise mundial e aos } \\
\text { movimentos sócio-ambientalistas, } \\
\text { além do fortalecimento dos } \\
\text { organismos de proteção, surge } \\
\text { uma nova mentalidade de não } \\
\text { dissociação entre economia e } \\
\text { ecologia } \rightarrow \text { desenvolvimento } \\
\text { sustentado. }\end{array}$ & $\begin{array}{l}\text { Ocorre a institucionalização de } \\
\text { entidades governamentais e não } \\
\text { governamentais específicas ao meio } \\
\text { ambiente. Devido o reconhecimento } \\
\text { dos efeitos globais, surgem fortes } \\
\text { pressões sobre o governo brasileiro a } \\
\text { respeito da Amazonia: cria-se em } \\
1989 \text { o BBAMA. O sócio- } \\
\text { ambientalismo evidencia-se no Brasil } \\
\text { com os seringueiros, os índios, os } \\
\text { sem-tera, os moradores de periferias } \\
\text { e alguns sindicatos. }\end{array}$ \\
\hline $90 \mathrm{~s}$ & $\begin{array}{l}\text { Profissionalização } \\
\text { e valor economico }\end{array}$ & $\begin{array}{l}\text { No início dos anos novena, a } \\
\text { abordagem dada ao meio } \\
\text { ambiente caracteriza-se pela } \\
\text { interdisciplinaridade e } \\
\text { valorização economica. }\end{array}$ & $\begin{array}{l}\text { Avanço da legislação para as } \\
\text { questôes ambientais toma-se } \\
\text { evidente. Efetivação do } \\
\text { enquadramento das bacias. A } \\
\text { educação ambiental ainda se restringe } \\
\text { apenas a campanhas esporádicas. }\end{array}$ \\
\hline
\end{tabular}

Tabela 1 - A percepção do meio ambiente $x$ economia. 
Muitas soluções adotadas pelo poder público implicaram em equívocos metodológicos e no tratamento isolado das questões de desenvolvimento sem a consideração das ecológicas, resultando em grandes impactos sobre o ecossistema. Uma nova leitura ao se gerir a problemática ambiental no planeta se fáz necessária, uma vez. que os impactos não respeitam fronteiras políticas. Em ONU (1988), Nosso futuro comum, tem-se o crescimento populacional e industrial como principais causas da crise ambiental, apontando para uma inversão de preocupações e, conseqüentenente, de valorizações. Antes se temia o impacto da economia sobre o meio ambiente, hoje em dia, é o impacto da degradação ambiental sobre a economia que conta, caracterizando a gênese do desenvolvimento sustentável.

Bezerra (1996) afirma que a gestão ambiental "caracteriza-se como uma ação centrada na tomada de decisão sobre casos particularizados, mediando conflitos inerentes à utilização de recursos naturais para atendimento das demandas sócioeconômicas e das ações de conservação ambiental". A essa definição poderíamos acrescentar ações de recuperação. Assim sendo, para uma eficaz política ambiental, as seguintes considerações são necessárias:

- presença do Estado, como gestor e promovedor das transformações organizacionais nacionais, onde o mesmo não pode arcar sozinho com todos as despesas envolvidas;

- ineficácia de ações meramente restritivas, punitivas e/ou prescritivas;

- a indissociabilidade entre questão ambiental e desenvolvimento;

- compartilhar decisões entre estado, setor privado e sociedade civil, atribuindo valores (preço) aos recursos naturais.

Quanto as principais diretrizes políticas organizadas na obra Nosso Futuro Comum, tem-se:

- a adequação entre o número de pessoas e os recursos disponíveis, eliminando a pobreza e garantindo um acesso mais justo para todos por meio da educação;

- o desenvolvimento do sistema de produção alimentar, com incentivos para os países pobres e para os pequenos produtores, assegurando-se uso de técnicas não abusivas e que protejam as áreas rurais;

- a proteção das diversas espécies, principalmente as em extinção, de forma a se garantir o desenvolvimento normal do ecossistema e da biosfera, atribuindo-se principalmente às florestas um uso econômico; 
- adotar técnicas produtivas e hábitos que consumam menos energia, adotando estratégias de substituição dos recursos não renováveis e investimentos em pesquisa, a manutenção das "tecnologias antipoluição" paralelamente a processos industriais cada vez mais eficientes, evitando-se o emprego de novos poluentes que possam superar os controles atuais,

- o controle da crise urbana, através de estratégias que orientem o processo de assentamento, desafoguem os grandes centros e promovam o desenvolvimento regional integrado.

Destacam-se como empecilhos à aceitação do desenvolvimento sustentado:

- relutância dos governos em mudarem suas posturas,

- dificuldade em reconhecer que os problemas são interdependentes e complementares,

- instituições com ações independentes e particularizadas,

- processos de decisão fechados, implicando em ações econômicas desvinculadas das ecológicas.

\subsection{Ocupação do solo e recursos hídricos}

Historicamente a escolha das áreas preferenciais para a fixação humana tem tido como premissa à oferta de água. A maioria dos assentamentos humanos tem um rio em seus atos de fundação, cuja utilização deixou de ser meramente orgânica para atender a demandas de ordem prática e em consonância com a complexidade das atividades econômicas. A revolução industrial na Europa, durante a segunda metade do séc. XIX, foi um marco nessa variação de atividades, quando impulsionou definitivamente o fenômeno da ocupação do solo e da urbanização. O homem do campo se transforma em operário e passa a habitar o entorno das fábricas.

No Brasil a industrialização teve mais força em meados do séc. $X X$, com recursos escassos e muitas vezes originados de empréstimos internacionais. O chamado milagre econômico desenvolveu a economia sem, entretanto, eliminar as desigualdades regionais existentes. Esse quadro de desigualdade, pautado nos ideais capitalistas de produção eficiente e em larga escala, incrementou a má distribuição da população que, associado ao seu próprio crescimento, resultou na concentração populacional. Com isso, 
deslocou-se definitivamente o poder para as cidades, passando a zona rural à mera coadjuvante nas decisóes.

Em relação aos recursos hídricos, o que se evidencia atualmente é uma incongruência entre a demanda e oferta desse bem. As pessoas cada vez mais se aglutinam em áreas metropolitanas, ocasionando a escassez de água, regionalmente e o racionamento, mais pontualmente. Com o tempo, a concentração populacional causaria o esgotamento do meio ambiente local, inviabilizando a sustentabilidade de mananciais, áreas verdes e do próprio espaço. que por sua vez, estimularia processos ilícitos de ocupação, e ainda, a convivência desgastante entre indústrias e pessoas numa mesma área.

Como exemplo tem-se a Região Metropolitana de Belo Horizonte (RMBH), localizada, em sua maior parte, na bacia do Rio das Velhas, foi obrigada a importar água da bacia do Rio Paraopeba de forma a equilibrar o abastecimento público.

\subsection{Justificativa e Objetivos}

A bacia do Ribeirão Serra Azul se torna interessante para pesquisa por ser esta responsável pelo abastecimento público de parte da Região Metropolitana de Belo Horizonte (RMBH), e desta forma, contar com dados que caracterizam suas sub-bacias no tempo e no espaço.

A região apresenta mananciais com degradação proveniente da agricultura, mineração de ferro e da própria urbanização, sendo candidata a ter sua ocupação intensificada graças a sua proximidade à capital do estado e à região mais industrializada de Minas Gerais: os municípios de Betim e Contagem. Segundo Simões (1997), "A dinâmica de urbanização com seus conflitos sociais, contrapondo-se ao meio físico natural, ocorre em toda a sua complexidade nas áreas limites urbano-rural, promovendo inevitável expansão dos territórios periféricos"... "Na maioria das vezes a conversão do espaço rural em urbano é realizada de maneira a não considerar a diversidade da paisagem e o potencial de degradação de cada ambiente físico". Além disso, esse trabaho procura descrever a dinâmica da qualidade da água e sua sustentabilidade, conforme a Figura 0. 


\section{Objetivo geral:}

Ampliar o estudo sobre gestão de bacias hidrográficas, especialmente a do Ribeirão Serra Azul, ao analisar a evolução do uso do solo e da qualidade da água no tempo e no espaço.

\section{Objetivos específicos:}

- Gerar, compilar e disponibilizar dados referentes ao meio físico e sua ocupaçăo;

- Analisar a dinâmica da qualidade da água e o ciclo hidrológico;

- Comparar a qualidade da água e a ocupação do solo nas diferentes sub-bacias;

- Identificar áreas de maior prioridade para o controle da degradação caracterizada pela qualidade e o uso da água.

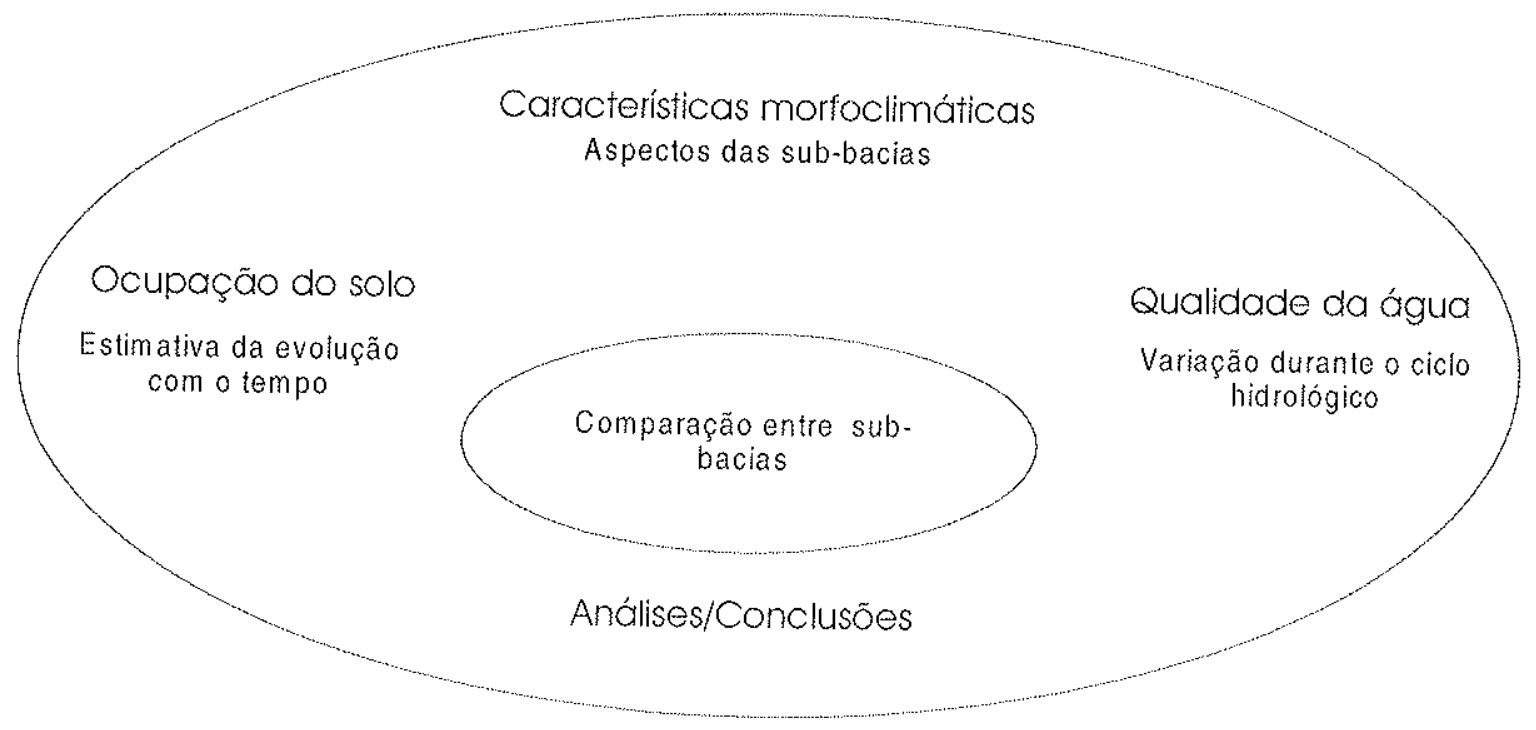

Figura 0 - Esquema geral da pesquisa. 


\section{A Bacia Hidrográfica do Ribeirão Serra Azul}

A Bacia Hidrográfica do Ribeirão Serra Azul localiza-se a oeste da Região Metropolitana de Belo Horizonte, na porção mais ocidental do Quadrilátero Ferrífero. Abrange parte dos municípios de Mateus Leme, Igarapé, Juatuba e Itaúna, possuindo uma área aproximada de $270 \mathrm{~km}^{2}$. Figura 1.

A bacia tem ao sul, trecho da BR 381 como via de acesso para Belo Horizonte e São Paulo, estando ainda, próxima à BR 262, acesso para o Triangulo Mineiro, e à rodovia estadual MG 050, que alcança Divinópolis e o interior do estado de São Paulo.

\subsection{Geomorfologia}

A Serra Azul constitui-se o principal divisor de águas da região em pauta, definindo a extremidade sudoeste da Serra do Curral e, por sua vez, do Quadrilátero Ferrífero. Sendo um prolongamento do trecho nomeado Serra da Moeda, tem seu ponto culminante no Pico do Itatiaiuçu a $1434 \mathrm{~m}$ de altitude.

A principal drenagem da área de estudo é o Ribeirão Serra Azul, que nasce na Serra Azul e segue na direção SW-NE, desaguando na margem esquerda do Rio Paraopeba, no município de Juatuba. A partir da construção do reservatório e conseqüente barramento de seu curso, os seus principais afluentes, os ribeirões Curralinho, Potreiro, Estiva, Diogo e Jacu, passaram a contribuir para o lago, juntamente com suas bacias. Antes da construção do reservatório, o nível de base do Rio Paraopeba era o que controlava regionalmente a erosão natural do relevo da bacia do Serra Azul, que, de certa forma, possui terrenos ondulados e com vales abertos, enquanto os baixios seriam ocupados por aluvióes. Em termos gerias, suas drenagens seriam mais sinuosas que lineares.

A figura 2 , representa as sub-bacias do Serra Azul e suas drenagens principais. 


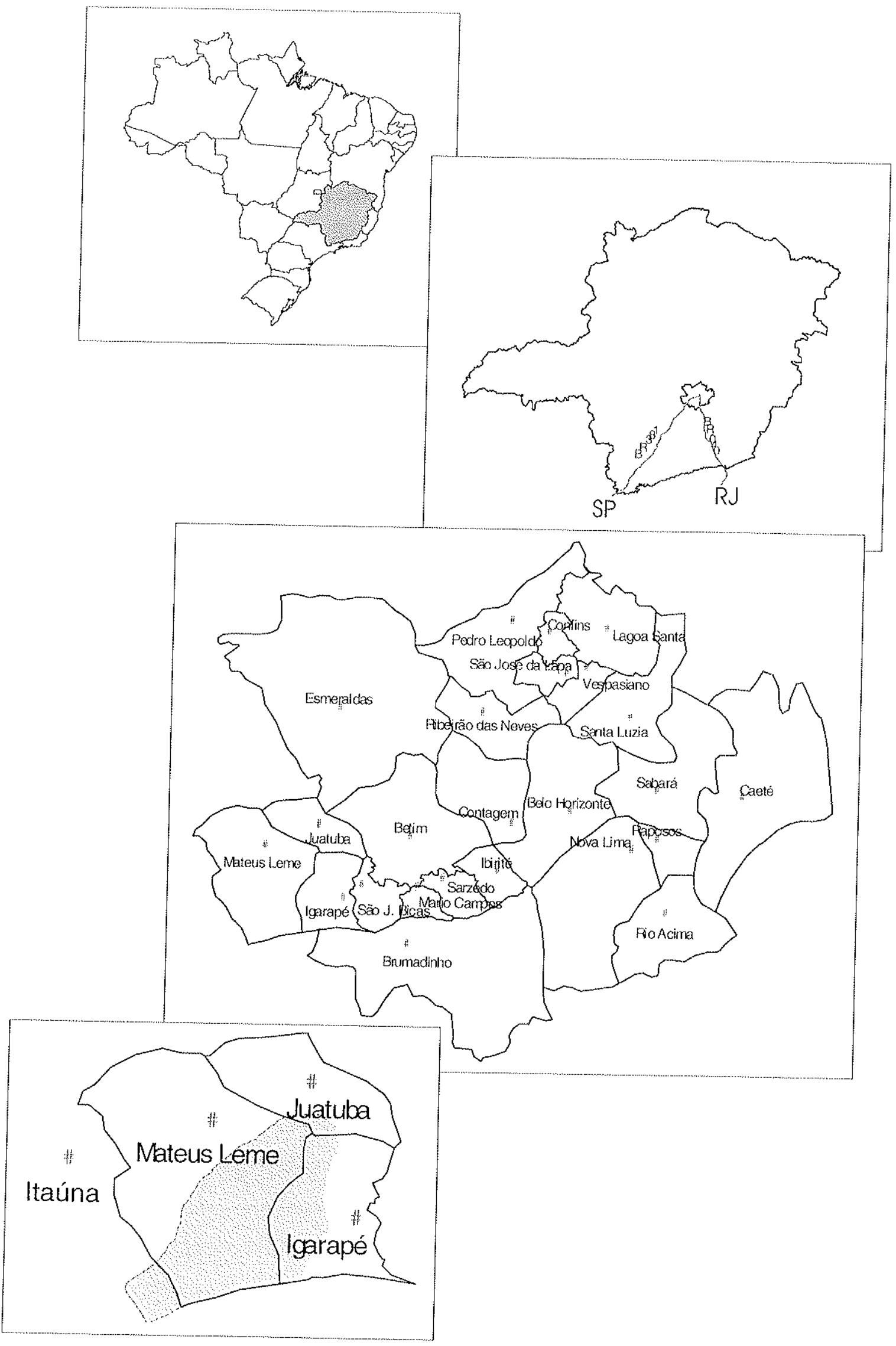

Figura 1 - Localização da Bacia do Ribeirão Serra Azul: No país, no Estado de Minas Gerais, na Regiāo Metropolitana de Belo Horizonte (RMBH), e nos municípios. 


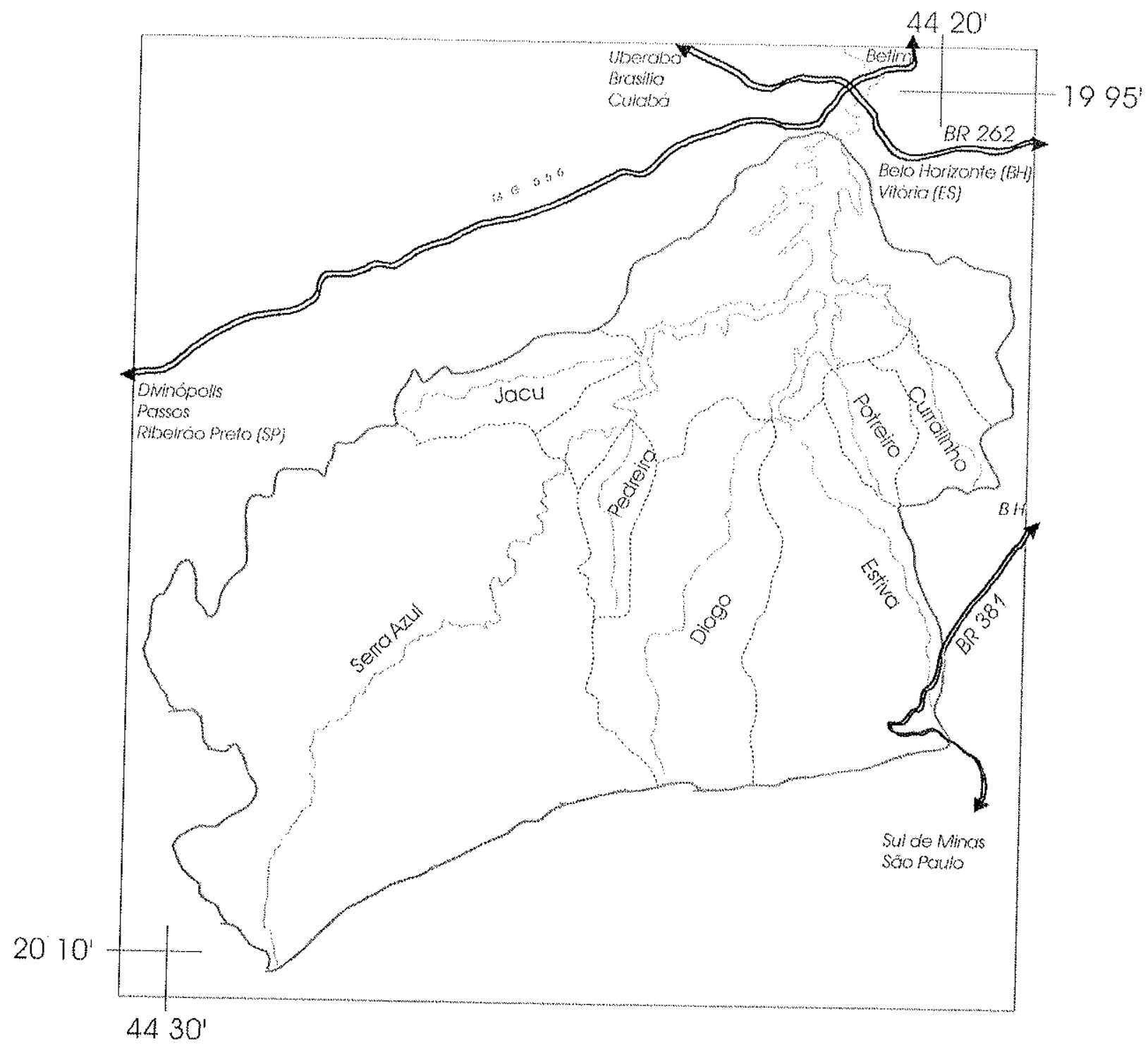

Figura 2 -- Bacia do Ribeinão Serra Azul.

As terras locais podem ser divididas em quatro grupos, IGA (1985):

- planícies de aluvião: em pequenas faixas ao longo do Ribeirão Serra Azul;

- planícies: entre as cotas de 800-900m, compreendem os depósitos terciários e quaternários, oriundos do intemperismo sofrido pela Série Minas sobre rochas filíticas do Pré-cambriano.

- contrafortes: entre as cotas de 900-1000m, representam as meias-encostas e colinas;

- escarpas elevadas: cotas >1000, correspondendo à Serra Azul. 


\subsection{Geologia}

Os trabalhos de levantamento geológico existentes na área do Serra Azul estão dispostos nas Folhas Igarapé e Esmeraldas, na escala 1:50000, preparados pelo Instituto de Geociências Aplicadas (IGA) em 1983. Trata-se de uma compilação do levantamento efetuado pelo Departamento Nacional da Produção Mineral (DNPM) e o United States Geological Service (USGS), em escala 1:25000 e ainda, de trabalhos do próprio lGA.

A bacia drenada pelo ribeirão Serra Azul e seus tributários, constitui-se, litologicamente por rochas dos complexos graníticos e migmatíticos, e Série Minas. Recobrindo as planícies fluviais, as encostas e os pediplanos, têm-se solos aluvionais, colúvios e coberturas de detrito lateríticas, respectivamente. Quadro 1 e Figura 3.

\begin{tabular}{|c|c|c|}
\hline Quaternário & & $\begin{array}{l}\text { Depósitos aluvionares inconsolidados de } \\
\text { areia, argila e cascalho, próximos aos cursos } \\
\text { de água. }\end{array}$ \\
\hline Terciário/Quaternário & & $\begin{array}{l}\text { Depósitos coluvionares: blocos de itabiritos e } \\
\text { hematita parcialmente cimentados por } \\
\text { limonita. Eluvio-coluvionares: representados } \\
\text { por canga limonítica e laterita ferruginosa. }\end{array}$ \\
\hline Terciário & & $\begin{array}{l}\text { Depósitos fluviais: finos leitos de arenitos e } \\
\text { argilitos interestratificados, algum } \\
\text { conglomerado. }\end{array}$ \\
\hline Pre-cambriano Inferior & $\begin{array}{l}\text { Supergrupo } \\
\text { Minas }\end{array}$ & $\begin{array}{l}\text { Grupo Piracicaba } \\
\text { Formacão Sabará: xistos e metaconglomerado } \\
\text { Formação Fecho do Funil: filito marrom } \\
\text { escuro e prateado } \\
\text { Formação Cercadinho: quartzito cinzento e } \\
\text { filito prateado } \\
\text { Grupo Itabira: } \\
\text { Formação Itabirito/Cauê: itabirito compacto e } \\
\text { dolomítico, hematita friável e de alto teor. }\end{array}$ \\
\hline Arqueano & $\begin{array}{l}\text { Supergrupo } \\
\text { Rio das } \\
\text { Velhas }\end{array}$ & $\begin{array}{l}\text { Grupo Nova Lima } \\
\text { A: Sericita-clorita xistos, estaurolita-xistos, } \\
\text { clorita xistos, quartzo-clorita xistos. } \\
\text { B: quartzo-sericita xistos, sericita xistos, } \\
\text { clorita xistos e muscovita xistos. Pouca } \\
\text { formação ferrífera, } \\
\text { C: Quartizitos, quartizitos micáceos, filitos e } \\
\text { formação ferrífera. } \\
\text { Discordância }\end{array}$ \\
\hline
\end{tabular}


\begin{tabular}{|l|l|}
\hline & $\begin{array}{l}\text { Complexo Itaúna: gnaisses, migmatitos, } \\
\text { biotita gnaisses essencialmente. }\end{array}$ \\
\hline Quadro 1 - Coltuna Litoestratigráfica Simplificada Fonte: Mapeamento Geológico da Regiáo
\end{tabular} Metropolitana de Belo Horizonte, IGA/SECT/MG, COPASA (1983).

Em termos da Geologia Econônica, destaca-se a Formação Cauê, pertencente ao patamar médio do Super Grupo Minas, que é fonte de extensos depósitos de minério de ferro extraído na Serra Azul. O distrito mineral da Serra Azul é formado de protominério itabirítico, o itabirito silicoso, que após sofrer ação dos agentes intempéricos transforma-se em minério enriquecido de ferro. Basicamente, a composição química do itabirito silicoso é ferro e sílica, a ação do intemperismo sobre este tipo de rocha tem como resultado principal a lixiviação da sílica e a concentração do ferro.

Lavras de pequeno porte de grafita ocorrem na regiăo, posicionadas no Grupo Nova Lima do Supergrupo Rio das Velhas.

\subsection{Clima}

O estudo dos dados disponibilizados sobre temperatura e pluviometria da bacia do Serra Azul, revelou que a estação climatológica Fazenda Cavalo, localizada dentro da área de proteção do reservatório da COPASA, apresentava o maior período de medições, Anexo 1. Tais séries incluíam os anos de 1986 a 1998 e tiveram as medianas mensais dispostas nos Gráficos 1 e 2. Comparando esses gráficos, percebe-se dois períodos para a temperatura, inverno e verão, e outros dois para a precipitação, seco e úmido.

O período de inverno, referente aos meses de abril a setembro, coincide com o seco. Por outro lado, o verão coincide com o úmido nos meses de outubro a março, corroborando a classificação de Koppen: mesotérmico úmido do tipo CWa, caracterizado por inverno seco e verão chuvoso com temperatura média superior a 20 ${ }^{\circ} \mathrm{C}$. Em análise mais detalhada, constatou-se que a temperatura média do período de inverno é de $18,8^{\circ} \mathrm{C}$, e no verão $22,7^{\circ} \mathrm{C}$. Tendo máximo de $25,5^{\circ} \mathrm{C} \mathrm{cm}$ fevereiro e mínimo de $13,7^{\circ} \mathrm{C}$ em julho. 


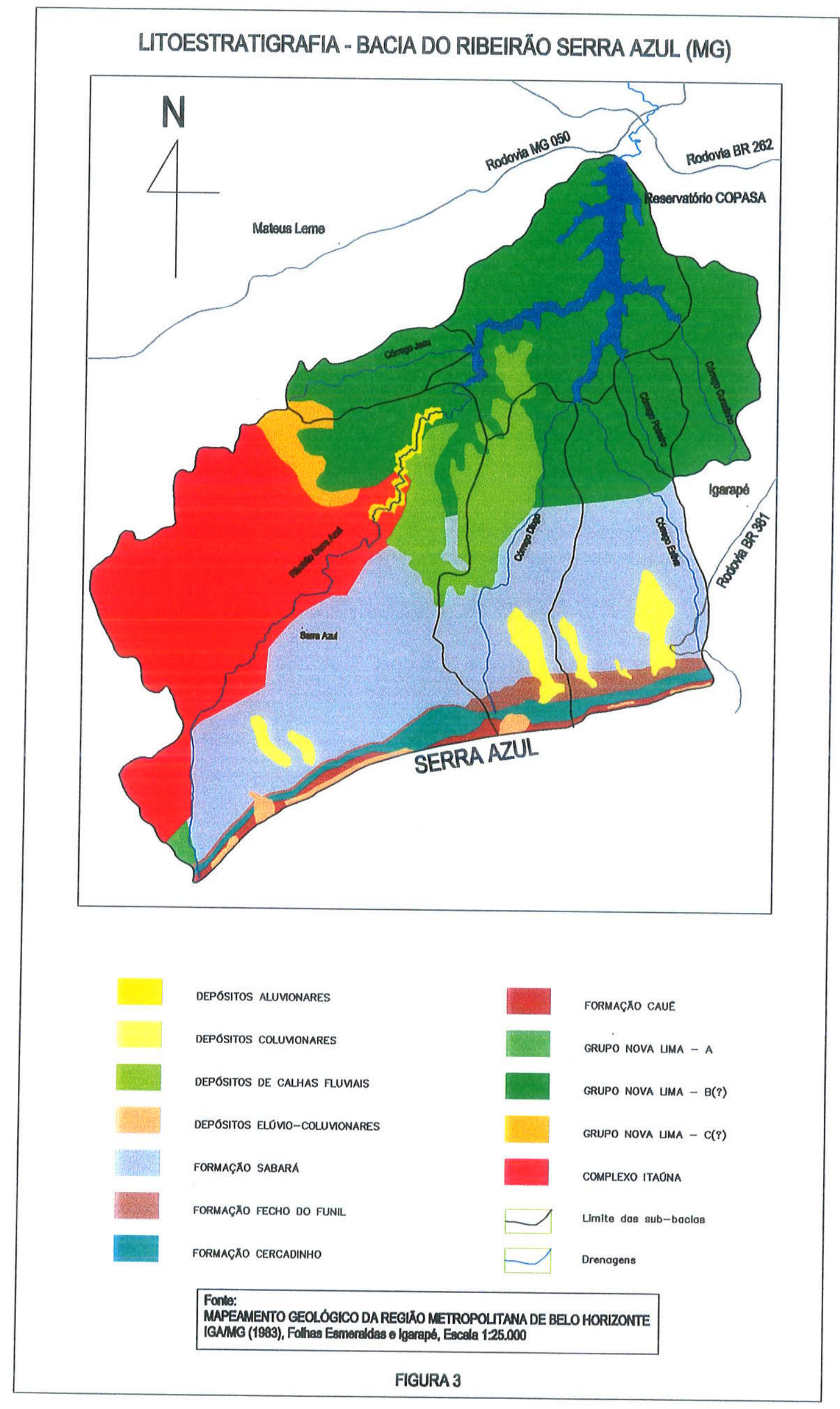




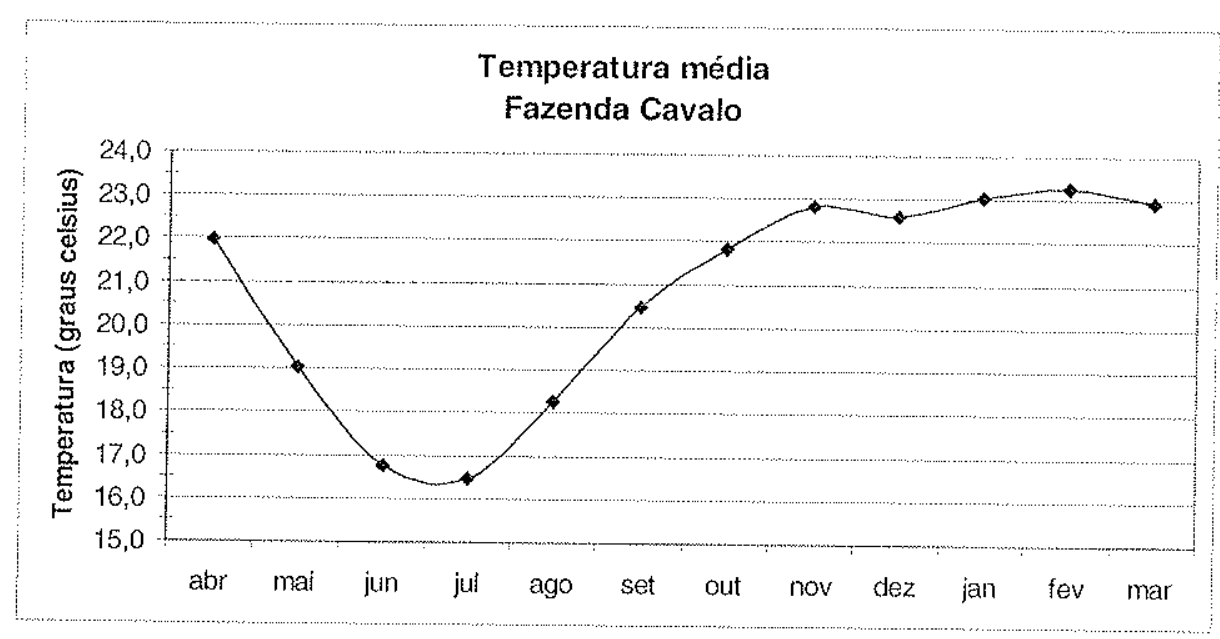

Gráfico 1 - Temperatura média, estação Fazenda Cavalo.

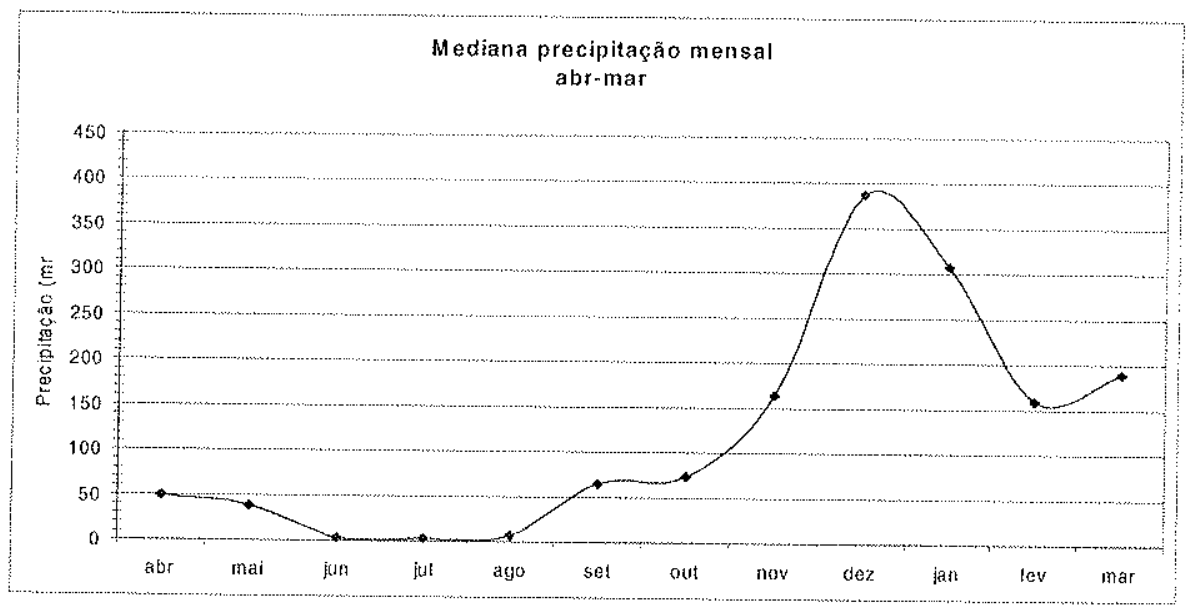

Gráfico 2 -- Precipilação Mediana - Fazenda Cavalo. (abr-már)

A representação da precipitação anual começando em abril e terminando em março do ano seguinte, Gráfico 2, difere-se daquela que utiliza o calendário civil, Gráfico 3, pois, além de respeitar os períodos hidrológicos, os tornam mais evidentes à medida que retona um gráfico semelhante a uma hidrógrafa, gráficos 1 e 2 . Seria como se todo o período úmido se tratasse de uma ou mais chuvas que caíram na bacia durante o ano.

A irregularidade da distribuição das chuvas é marcante durante o ano, ficando para o período seco, de abril a setembro, aproximadamente $15 \%$ da precipitação anual, e 
os $85 \%$ restantes, para os meses de outubro a março do ano seguinte. Os gráficos 4 e 5 , representam a precipitação anual total e ainda as parcelas referentes aos meses do período úmido e seco durante os anos de 1986 a 1998. A precipitação está disposta no eixo $\mathrm{Y}$ de forma que ao eixo $\mathrm{X}$ coube representar os anos hidrológicos, definidos de duas maneiras: a partir do início do período seco (abril-março), e de acordo com o ano civil convencional (janeiro-dezembro).

Comparando-se os mesmos, constata-se que o gráfico representando o período de abril-março se apresenta mais ordenado, indicando poder haver um intervalo de dois anos entre cada pico de precipitação. Em ambos nota-se uma tendência geral de crescimento da precipitação na década.

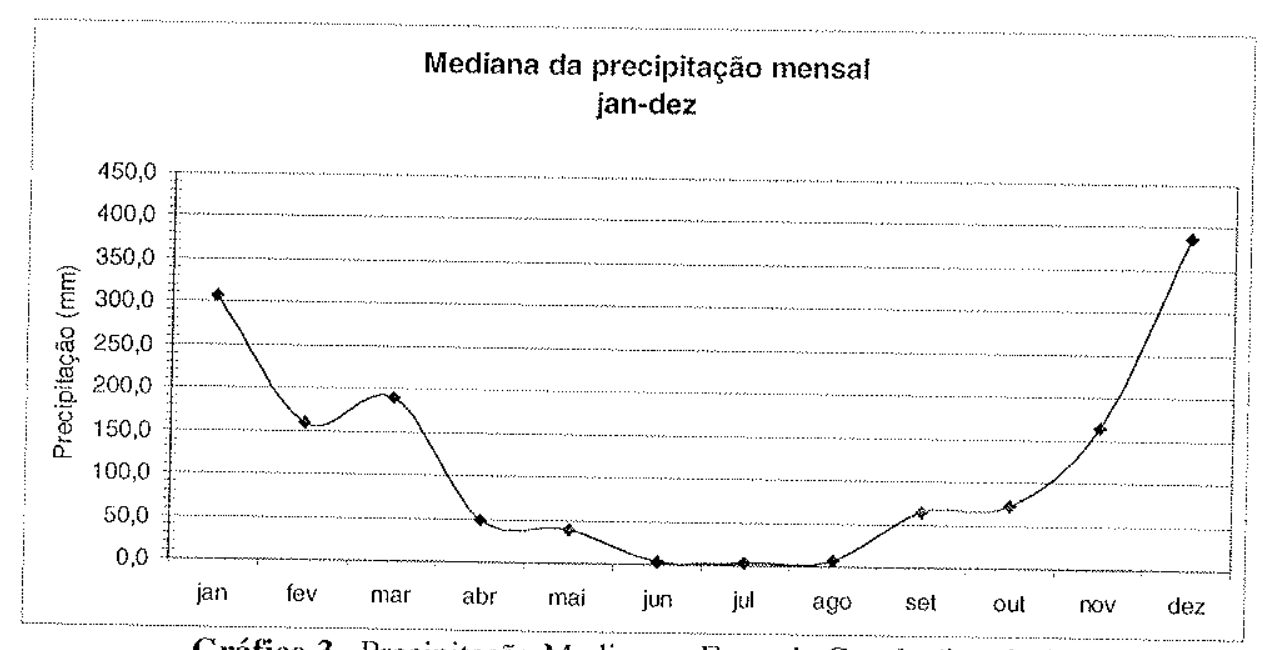

Gráfico 3-Precipitação Mediana - Fazenda Cavalo (jan-dez).

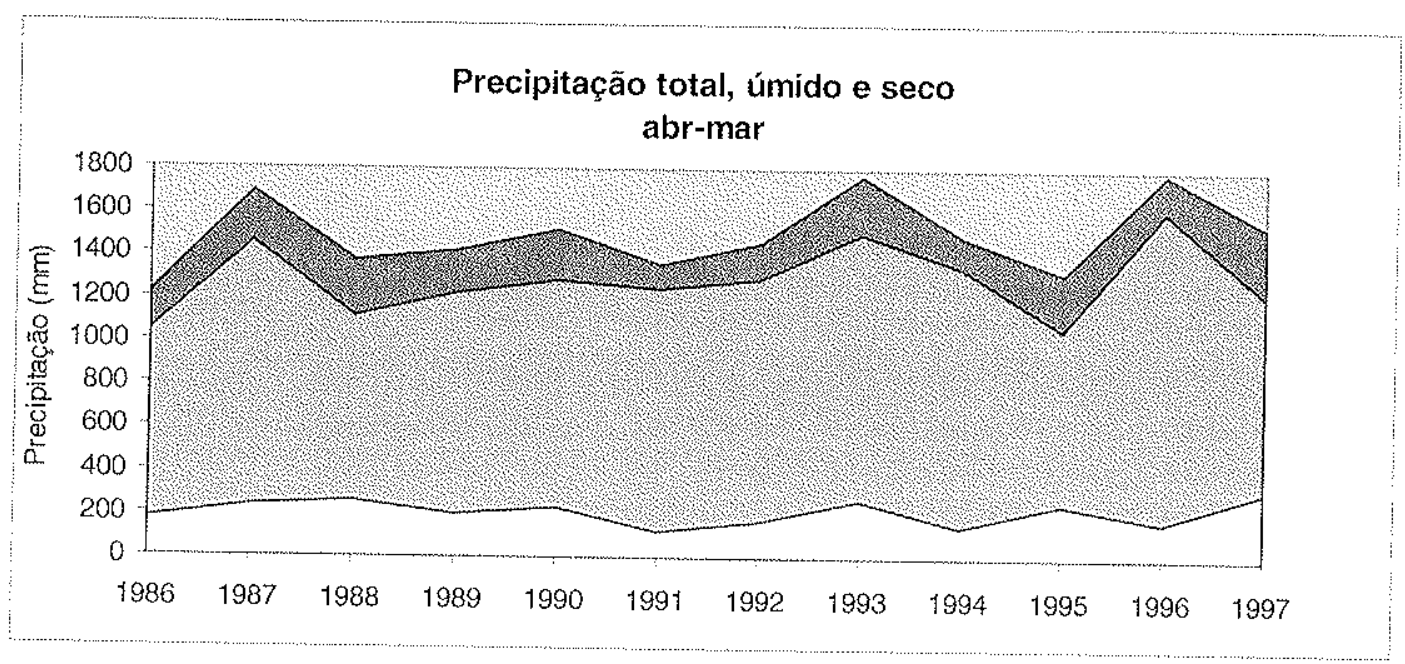

Gráfico 4 -... Precipitação total, estação Fazenda Cavalo (abr-mar) 


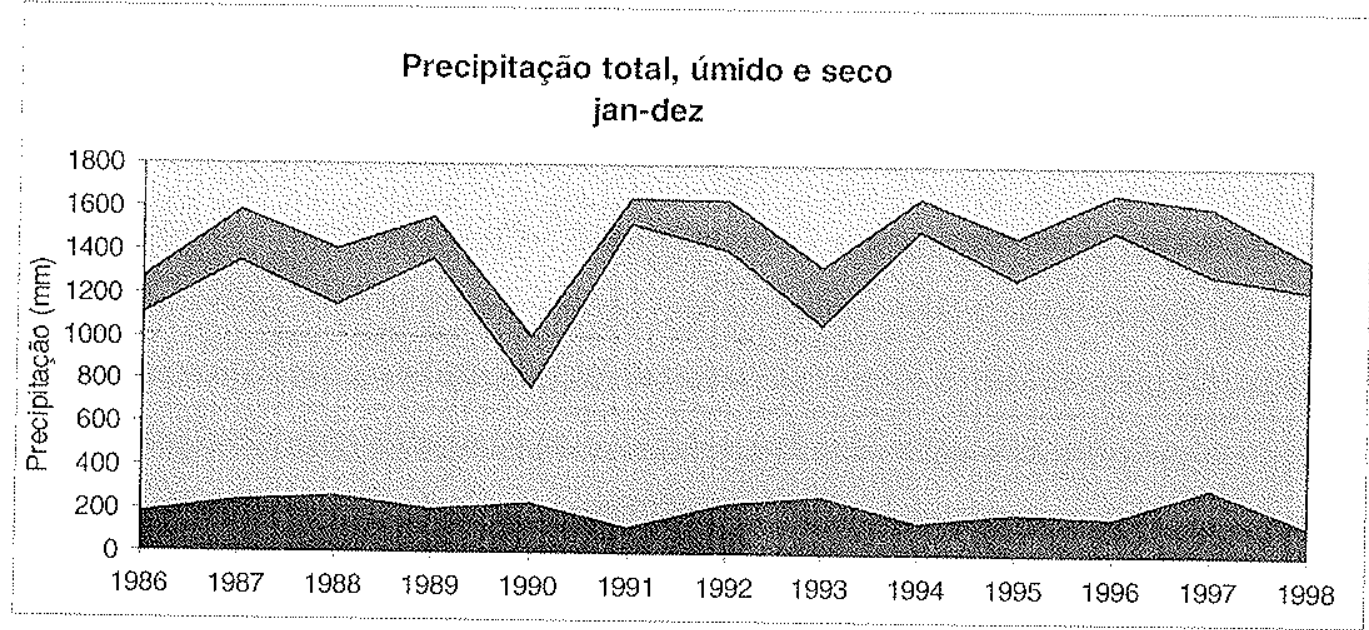

Gráfico 5 - Precipitação total, estação Fazenda Cavalo ( jan-dez)

A precipitação mediana anual foi obtida a partir do preenchimento das falhas mensais com a respectiva mediana mensal, ficando em torno de $1557,9 \mathrm{~mm}$. Entretanto, esse valor pode ser minorado se for considerada a soma das medianas mensais: 1485,2 $\mathrm{mm}$.

\subsection{Sócio-Economia}

A bacia Serra Azul, localizada na fronteira de 4 municípios, abrange setores urbanos, como aqueles do Distrito de Serra Azul, município de Mateus Leme, ou mesmo bairros do Município de Igarapé; e ainda, os setores rurais, distribuídos em partes dos territórios de Itaúna, Igarapé, Juatuba e Mateus Leme. Entretanto, se nos basearmos na população total por munićpio do $\mathrm{BBGE}$, veremos que é uma região que tem crescido em torno de $4 \%$ ao ano. Gráfico 6 . Estima-se que a população total na bacia esteja em torno de 10.000 habitantes. 


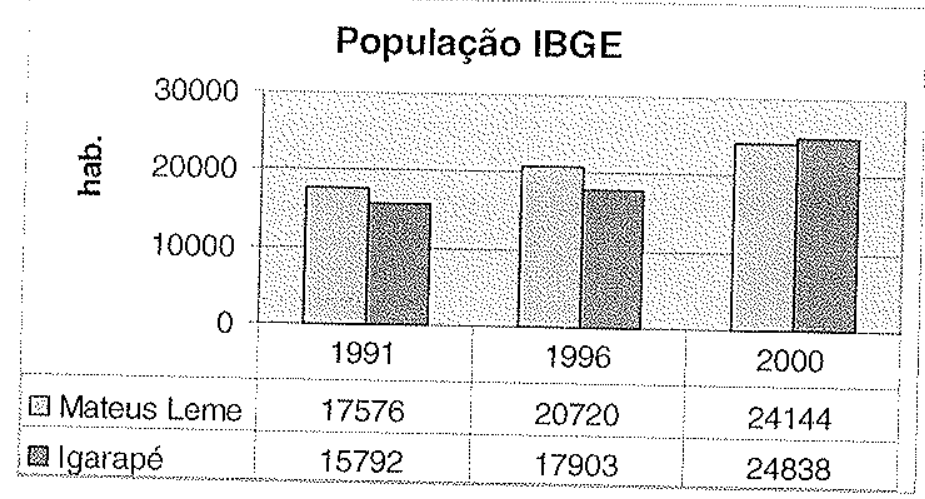

Gráfico 6 -.. Populações de Igarapé e Mateus Leme. Fonte: IBGE.

A área urbana do distrito de Serra Azul conta com aproximadamente 5.000 habitantes e um sistema de abastecimento de água deficitário. O esgotamento sanitário também não atende a todos, sendo despejado no ribeirão Serra Azul sem tratamento. A região possui escolas públicas de ensino fundamental. A maioria dos moradores se encontra na periferia dos municípios, obrigando-os a depender de um sistema de transporte precário para usufruírem os serviços urbanos.

A base econômica da bacia seria a agropecuária e a mineração. Na agricultura, destaca-se os hortifrutíferos, comercializados principalmente na Central de Abastecimento S/A (CEASA-MG), em Contagem: tomate, pepino, vagem, pimentão, abobrinha, entre outros. Ocorre ainda, mas com menor intensidade, as culturas de milho, feijão, café, canande-açúcar e forrageiras. O Gráfico 7 mostra que a produção se expandiu no período de 1994 a 1998.

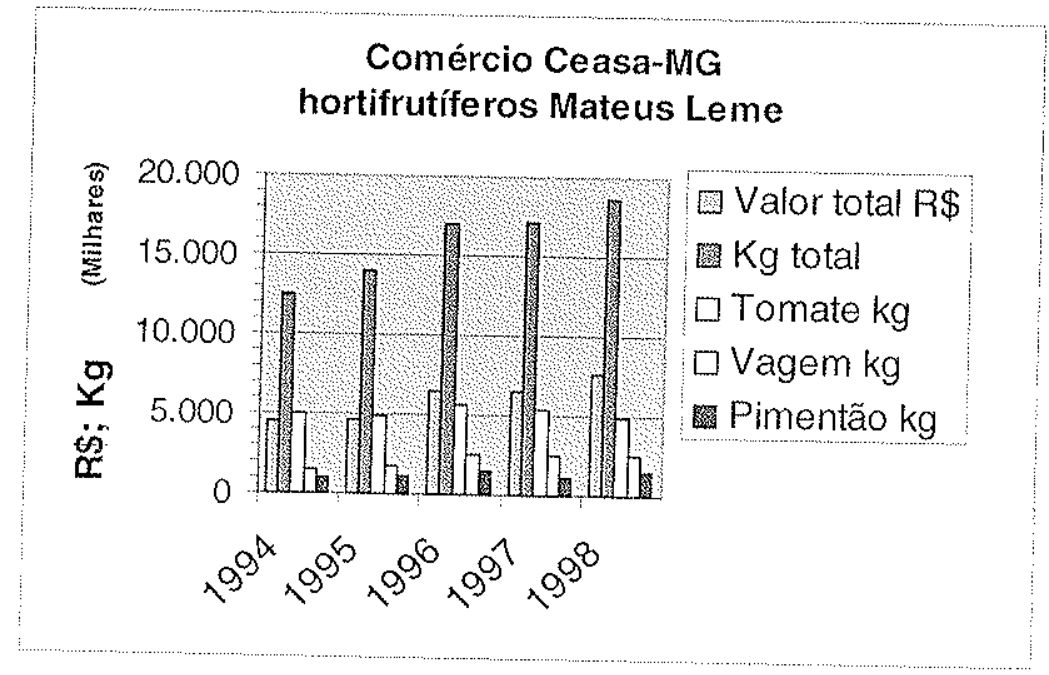

Gráfico 7 - Produção de hortifrutiferos. 
O Gráfico 8 e o Quadro 2, ilustram o desempenho da mineração de ferro na Serra Azul, que também tem apresentado crescimento. Como a contribuição financeira para aos municípios pelas mineradoras locais, corresponde a $2 \%$ do faturamento líquido apurado no comércio da bem extraído, tem-se que em 2001, o minério de ferro movimentou na Serra Azul mais de 18 mi de reais.

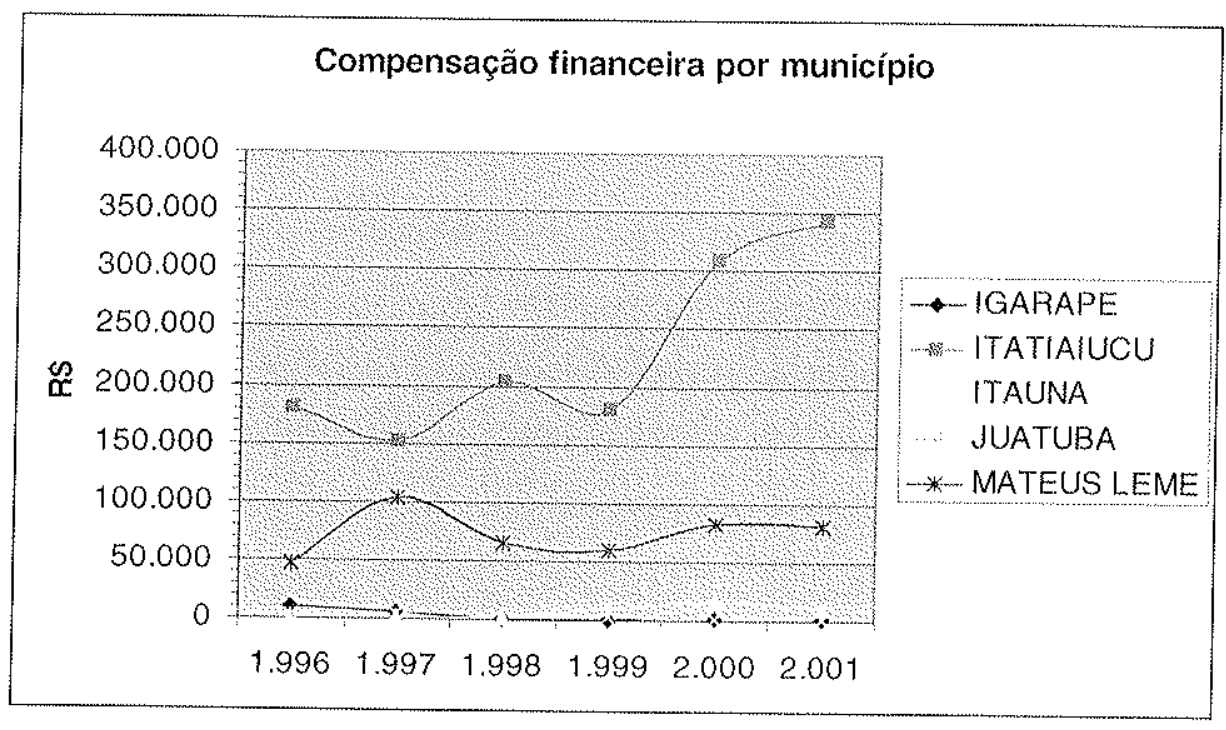

Gráfico 8 - Compensação financeira devida à exploração mineral. Fonte: DNPM

\begin{tabular}{|c|c|c|}
\hline \multicolumn{3}{|l|}{ MINÉRIO DE FERRO } \\
\hline \multirow{2}{*}{\multicolumn{3}{|c|}{ Compensação financeira 2001}} \\
\hline & $R \$$ & 342.348 .81 \\
\hline MATEUS LEME & $\mathrm{R} \$$ & $25.735,89$ \\
\hline Total arrecadado na S.Azul & $\mathrm{R} \$$ & $368.084,70$ \\
\hline \multicolumn{3}{|c|}{ Que corresponde a $2 \%$ do faturamento líquido c/ venda } \\
\hline $100 \%$ faturamento & $R \$$ & $18.404 .235,00$ \\
\hline $100 \%$ farutamento em M. Leme & $R \$$ & $1.286 .794,50$ \\
\hline $100 \%$ farutamento em Itatiaiucu & $\mathrm{RS}$ & $17.117 .440,50$ \\
\hline
\end{tabular}

Fonte: DNPM

Quadro 2-Recursos financeiros envolvidos na mineração local

Outras atividades econômicas seriam a fábrica de sementes, laticínio e ainda, as propriedades rurais produtoras de cachaça e produtos de origem animal. Em trabalhos anteriores e em campo, apurou-se os empreendimentos no histórico da bacia, Tabela 2. 


\begin{tabular}{|c|c|c|}
\hline Atividade & Sub-bacia & Observações \\
\hline $\begin{array}{l}\text { Mineração de ferro } \\
\text { Delzir Batista }\end{array}$ & Serra Azul & $\begin{array}{l}\text { Desativada em meados da década de } 80 . \\
\text { Não houve recuperação da área do córrego } \\
\text { do Pacheco. }\end{array}$ \\
\hline $\begin{array}{l}\text { Mineração de ferro } \\
\text { Minerita }\end{array}$ & Serra Azul & $\begin{array}{l}\text { Produz minério britado e lavado. Rejeitos } \\
\text { são lançados pela encosta da serra. Foi } \\
\text { executada barragem de finos no pé da } \\
\text { pilha, entretanto ombreira esquerda precisa } \\
\text { de reparos. }\end{array}$ \\
\hline $\begin{array}{l}\text { Mineração de ferro J. } \\
\text { Mendes }\end{array}$ & Serra Azul & $\begin{array}{l}\text { Produz minério britado e lavado. Possui } \\
\text { lagoas de contenção. }\end{array}$ \\
\hline $\begin{array}{l}\text { Mineração de ferro } \\
\text { Hércules }\end{array}$ & Serra Azul & $\begin{array}{l}\text { Produz minério de ferro britado e lavado } \\
\text { na bacia vizinha desde } 1985 \text {, entretanto } \\
\text { lança rejeitos, principalmente grossos, na } \\
\text { encosta da serra. }\end{array}$ \\
\hline $\begin{array}{l}\text { Mineração de ferro Rio } \\
\text { Grande }\end{array}$ & Estiva & $\begin{array}{l}\text { Desativada na década de } 1980 \text {. Sem } \\
\text { informações sobre a recuperação da área. }\end{array}$ \\
\hline $\begin{array}{l}\text { Mineração de ferro } \\
\text { Fernão Dias }\end{array}$ & Estiva & $\begin{array}{l}\text { Produz minério de ferro britado e lavado. } \\
\text { Localizada na divisa com a bacia do Rio } \\
\text { Manso, seu avanço influenciou nascentes } \\
\text { na bacia do S. Azul. }\end{array}$ \\
\hline $\begin{array}{l}\text { Mineração de ferro } \\
\text { Conquistinha }\end{array}$ & Estiva & $\begin{array}{l}\text { Produz minério de ferro britado e lavado. } \\
\text { Localizada na divisa com a bacia do Rio } \\
\text { Manso, seu avanco afetou nascentes na } \\
\text { bacia do S. Azul. }\end{array}$ \\
\hline $\begin{array}{l}\text { Mineração de ferro Serra } \\
\text { da Farofa }\end{array}$ & Estiva & $\begin{array}{l}\text { Produz minério de ferro britado e lavado. } \\
\text { Localizada na divisa com a bacia do Rio } \\
\text { Manso, seu avanço influenciou nascentes } \\
\text { na bacia do S. Azul. }\end{array}$ \\
\hline $\begin{array}{l}\text { Mineração de grafita sem } \\
\text { registro }\end{array}$ & Serra Azul & $\begin{array}{l}\text { Produz grafita de maneira rudimentar e } \\
\text { sem projeto de proteção ambiental. }\end{array}$ \\
\hline $\begin{array}{l}\text { Mineração de grafita } \\
\text { Serra Azul }\end{array}$ & Serra Azul & $\begin{array}{l}\text { Produz grafita britada. Localizada na área } \\
\text { urbana do distrito, possui pequena } \\
\text { barragem de rejeitos que não suportaria a } \\
\text { expansão pretendida. }\end{array}$ \\
\hline \begin{tabular}{lll|}
$\begin{array}{l}\text { Mineração de ferro } \\
\text { Pitangui }\end{array}$ & \\
\end{tabular} & Estiva & $\begin{array}{l}\text { Não recuperou canais assoreados. } \\
\text { Operação incerta. }\end{array}$ \\
\hline $\begin{array}{l}\text { Indústria de Sementes } \\
\text { Agroceres S/A }\end{array}$ & Estiva & Agroindústria com área de 83 ha. \\
\hline Laticínio Estância & Diogo & $\begin{array}{l}\text { Sem informações sobre a operação. } \\
\text { Efluentes lançados no Diogo. }\end{array}$ \\
\hline Metalúrgica Fornac & Estivat & $\begin{array}{l}\text { Desativada em 1982. Bombeava água do } \\
\text { córrego do Diogo, aprox. } 1000 \mathrm{~m} 3 / \text { dia. }\end{array}$ \\
\hline Metalúrgica Lafersa & Estiva & $\begin{array}{l}\text { Desativada aprox. em 1979. Sem } \\
\text { informações. }\end{array}$ \\
\hline
\end{tabular}

Tabela 2 - Empreendimentos de escala indastral presentes ao Jongo da historia da bacia Serra Azul. Fonte: COPASA (1983) e campo. 


\section{Qualidade da Água}

\subsection{Conceitos}

A Qualidade da Água (QA), seria determinada por um conjunto de variáveis que a caracterizariam em determinado momento através de indicadores das condições físicas, biológicas, ou mesmo, das medidas de concentrações de substâncias diversas.

A qualidade da água superficial em lagos, terras úmidas, rios e mesmo riachos, é resultado de sua interação com os solos, rochas, sólidos transportados e da própria atmosfera, além de ser influenciada pela água subterrânea e grandemente pela ocupação do solo na bacia hidrográfica, ou seja, os antropismos.

A determinação da qualidade da água superficial é tida como complexa, dada a sua possibilidade de variação no tempo e no espaço. Entretanto, para concluir se determinada água é boa ou não, torna-se necessário ter em mente o que se pretende fazer com ela. Dessa forma, não se deve dissociar a qualidade e o uso da água, compreendendo que cada uso distinto da água implica em restrições específicas às variáveis.

Nessa mesma linha, o termo poluição estaria relacionado a alterações nas características da água de forma que determinada utilização fosse impedida ou prejudicada. A poluição pode prejudicar a saúde humana e a vida de diversos organismos, além das atividades econômicas, ocorrendo através da introdução de matéria ou energia.

\subsection{Gerenciamento}

O gerenciamento da QA deve atuar de forma a conceber as alterações das variáveis ocorridas no âmbito da bacia, e ainda, permitir alcançar o uso a que ela se destina. A determinação da capacidade assimilativa dos corpos d'água e ainda, a adoção de critérios e padrões de qualidade, materializam os elementos balizadores das ações de gestão dos recursos hídricos. 
Como critérios, entende-se os valores estabelecidos cientificamente e que relacionam as variáveis aos seus efeitos no meio ambiente (incluindo a saúde humana).

Os padrões seriam intervalos de valores estabelecidos por lei para determinado corpo hídrico. Estando relacionados ao uso da água, os padrões ajudam a preservar a qualidade da água, e ainda, servem como referencial para o tratamento de efluentes na bacia. Quadros 3 e 4.

\subsection{Enquadramento}

O primeiro padrão de qualidade para o ribeirão Serra Azul surgiu de maneira mais formal quando suas águas foram enquadradas, até seu barramento, na Classe 1. Esse processo incluiu seus afluentes principais, os ribeirões Diogo, Potreiro, Curralinho, Estiva, Jacu e Brejo, e ainda, respeitou os principais usos da água na bacia do Serra Azul: o abastecimento público e a irrigação agxícola.

O enquadramento se deu através da Deliberaçào Normativa número 14, do Conselho Estadual de Política Ambiental (COPAM), de 28/12/1995, responsável pelo enquadramento geral do Rio Paraopeba, e ainda, de acordo com a lei estadual 7772 de 08/09/1985. Os objetivos do corpo hídrico enquadrado na classe 1 seriam:

- abastecimento doméstico, após tratamento simplificado.

- proteção das comunidades aquáticas.

- recreação de contato primário.

- irrigação de hortaliças que são consumidas cruas e de frutas que se desenvolvem rentes ao solo e que sejam ingeridas cruas sem remoção de película.

- criação natural e/ou intensiva de espécies destinadas à alimentação humana

No Brasil, o enquadramento dos cursos de água é um instrumento da Política Nacional de Meio Ambiente (PNMA), e do Plano Nacional de Recursos Hídricos (PNRH), e está regulamentado pela resolução 020/86 do Conselho Nacional do Meio Ambiente (CONAMA), que estabeleceu para o Brasil 9 classes de uso preponderante para as águas, sendo 5 classes para as águas doces, 2 classes para as águas salobras e 2 classes para as salinas. Essa resolução foi ratificada no estado de Minas Gerais pela deliberação normativa n ${ }^{\circ} 010$ do COPAM, de 16 de dezembro de 1986 , que estabeleceu 
ainda, normas e padröes para a qualidade das águas e do lançamento de efluentes, Quadro 3.

Nesses dispositivos legais fica caracterizado que o enquadramento dos cursos de água baseia-se nåo necessariamente no seu estado de qualidade atual, mas principalmente naquele estado de qualidade que deveria existir para atender às necessidades da comunidade local. A resolução do COPAM 010/86, define o enquadramento como sendo a determinação da "qualidade da água (classe de enquadramento) a ser alcançada ou mantida em um segmento de corpo de água ao longo do tempo". Dessa forma, o enquadramento deve ser estabelecido baseando-se na prioridade dos diversos usos das águas e respectivas qualidades existentes na bacia.

O processo de enquadramento em Minas Gerais é recente, estando dividido em três partes:

- Normativa, que consiste no levantamento dos usos preponderantes das águas, sua identificação e localização; posterior correlação dos usos principais com a qualidade exigida (classe) e finalmente, diagnóstico de uso e proposta de enquadramento trecho por trecho. Posteriormente, parte-se para a divulgação nos municípios envolvidos, seguida de pelo menos 3 audiências publicas a serem realizadas no alto, médio e baixo cursos. Tem-se então a proposta final do enquadramento, que retorna ao COPAM - Câmara de Recursos Hídricos e de Política Ambiental, sendo seu resultado transformado em deliberação normativa.

- Avaliação da Q.A., consistindo na amostragem da água e no levantamento de sua qualidade trecho a trecho, posterior comparação dos resultados com os padrões da classe de enquadramento a que cada trecho foi submetido na etapa anterior e estabelecidos no estado pela deliberação do COPAM 010/86.

- Efetivacão do enquadramento propriamente dita, envolvendo a elaboração do plano de implementação do enquadramento com caráter mais definitivo; apresenta as medidas a serem tomadas de forma a se adequar aos objetivos de qualidade estipulados, a realidade das águas.

Em todas as bacias enquadradas atualmente em Minas Gerais, apenas a primeira fase foi efetivada. 


\begin{tabular}{|c|c|}
\hline Aspectos & Limites e/ou condições \\
\hline $\begin{array}{r}\text { materiais flutuantes, inclusive espumas } \\
\text { não naturais }\end{array}$ & virtualmente ausentes \\
\hline óleos e graxas & virtualmente ausentes \\
\hline $\begin{array}{r}\text { substâncias que transmitam gosto e } \\
\text { sabor }\end{array}$ & virtualmente ausentes \\
\hline corantes artificiais & virtualmente ausentes \\
\hline $\begin{array}{r}\text { substâncias que formem depósitos } \\
\text { objetáveis }\end{array}$ & virtualmente ausentes \\
\hline coliformes & $\begin{array}{c}\text { virtualmente ausentes (hortaliças) ate } 200 \\
\begin{array}{c}\text { coliformes } / 100 \mathrm{ml} \text {, em } 80 \% \text { de pelo menos } 5 \text { amostras } \\
\text { (recreação) }\end{array}\end{array}$ \\
\hline $\mathrm{DBO}_{5}$ & $3 \mathrm{mg} / \mathrm{lO}_{2}$ \\
\hline $\mathrm{OD}$ & $6 \mathrm{mg} / 1 \mathrm{O}_{2}$ \\
\hline turbidez & $40 \mathrm{UNT}$ \\
\hline cor & $30 \mathrm{mgPt} / \mathrm{I}$ \\
\hline $\mathrm{pH}$ & $6,0-9,0$ \\
\hline ferro solúvel & $0,3 \mathrm{mg} / \mathrm{l} \mathrm{Fe}$ \\
\hline fosfato total & $0,025 \mathrm{mg} / \mathrm{l} \mathrm{P}$ \\
\hline manganês & $0,1 \mathrm{mg} / \mathrm{l} \mathrm{Mn}$ \\
\hline nitrato & $10 \mathrm{mg} / \mathrm{l} \mathrm{N}$ \\
\hline nitrito & $1.0 \mathrm{mg} / \mathrm{l} \mathrm{N}$ \\
\hline
\end{tabular}

Quadro 3 - QA para a Classe 1: Extrato da Deliberação COPAM 10/86.

\begin{tabular}{|l|c|c|c|c|c|}
\hline \multicolumn{1}{|c|}{ Variável } & $\begin{array}{c}\text { Portaria 36 } \\
\text { Ministério } \\
\text { da Saúde } \\
\mathbf{1 9 - 0 1 - 1 9 9 0}\end{array}$ & $\begin{array}{c}\text { Organização } \\
\text { Mundial da } \\
\text { Saúde } \\
\text { (OMS) }\end{array}$ & Canadá & EUA & Alemanha \\
\hline Cor (Pt/l) & 5 (aparente) & 15 & 15 & 15 & - \\
\hline Turbidez (UNT) & 1 & 5 & 5 & $1-5$ & - \\
\hline pH & $6,5-8,5$ & $6,5-8,5$ & $6,5-8,5$ & $6,5-8,5$ & $6,5-9,5$ \\
\hline Nitrato (mg/l N) & 10 & 10 & 10 & 10 & 50 \\
\hline Nitrito (mg/l N) & - & - & 1,0 & - & 0,1 \\
\hline Ferro total (mg/l Fe) & 0,3 & 0,3 & 0,3 & 0,3 & 0,2 \\
\hline Manganês (mg/l Mn) & 0,1 & 0,1 & 0,05 & 0,05 & 0,05 \\
\hline $\begin{array}{l}\text { Sólidos Totais } \\
\text { Dissolvidos (mg/l) }\end{array}$ & 1000 & 1000 & 500 & 500 & - \\
\hline $\begin{array}{l}\text { Coliformes fecais } \\
\text { (qtde./100ml) }\end{array}$ & 0 & 0 & 0 & - & - \\
\hline
\end{tabular}

Quadro 4 - Padróes de potabilidade para algumas variáveis de QA. CETESB (1990). 


\subsection{Impactos prováveis}

De maneira geral, os possíveis impactos sobre os recursos hídricos na bacia do Serra Azul, poderiam ser atribuídos aos efluentes e aos usos consumptivos da água.

As principais fontes de poluição difusa seriam as minerações, as áreas agrícolas e de pastagem. Pontualmente agiriam: o lançamento da rede coletora de esgotos da área urbana do distrito de Serra Azul e ainda, esgotos das unidades rurais e demais efluentes de alambiques e de pequenos produtores de leite e queijo.

Quanto ao consumo da água, pode-se dizer que os principais deles seriam irrigação agrícola e abastecimento público. O Quadro 5 , relaciona as fontes de poluição nãoindustrial e as variáveis de qualidade da água. 


\begin{tabular}{|c|c|c|c|c|c|c|c|}
\hline Variáveis & $\begin{array}{l}\text { Esgotose } \\
\text { efluentes } \\
\text { domésticos }\end{array}$ & $\begin{array}{l}\text { Run-off } \\
\text { urbano }\end{array}$ & Agricultura & Mineração & $\begin{array}{l}\text { Aterro } \\
\text { doméstico }\end{array}$ & $\begin{array}{l}\text { Aterros } \\
\text { químicos } \\
\text { perigosos }\end{array}$ & $\begin{array}{l}\text { Transporte } \\
\text { atmosférico }\end{array}$ \\
\hline Temperatura & Baixo & Baixo & Baixo & Baixo & & & \\
\hline Cor & Baixo & Baixo & Baixo & Baixo & Baixo & & \\
\hline Resíduos & Baixo & Baixo & Alto & Baixo & Alo & Médio & \\
\hline $\begin{array}{l}\text { Sólidos em } \\
\text { suspensão }\end{array}$ & Alto & Médio & Alto & Alto & Médio & Médio & \\
\hline Condutividade & Médio & Médio & Médio & Alto & Alo & $\Delta 110$ & Alto \\
\hline $\mathrm{pH}$ & Baixo & Baixo & Baixo & Alo & Médio & Alto & Alto \\
\hline Eh & Baixo & Baixo & Baixo & Baixo & & & \\
\hline $\mathrm{OD}$ & Alto & Alto & Alto & Alto & Ato & Ato & \\
\hline Dureza & Baixo & Baixo & Baixo & Baixo & & Baixo & Baixo \\
\hline Amônia & Ato & Médio & Alto & Baixo & Médio & & \\
\hline Nitrato/nitrito & Alto & Médio & Alto & Baixo & Médio & & Alto \\
\hline $\begin{array}{l}\text { Nitrogênio } \\
\text { orgânico }\end{array}$ & Alto & Médio & Alto & & Médio & & \\
\hline $\begin{array}{l}\text { Compostos } \\
\text { fosforados }\end{array}$ & Alto & Médio & Alto & & Baixo & & Baixo \\
\hline $\begin{array}{l}\text { Carbono orgânico } \\
\text { total }\end{array}$ & Baixo & Baixo & Baixo & Baixo & & & \\
\hline $\mathrm{DBO}$ & $A 1 t$ & Médio & Alto & Baixo & Alto & Médio & \\
\hline Cloro & Alo & Médio & Alto & Alto & Médio & Médio & \\
\hline Metais pesados & Médio & Médio & & Alto & Alto & Médio & baixo \\
\hline Pesticidas & & Baixo & Alto & & Médio & Alto & Alto \\
\hline Coliformes fecais & Alto & Médio & Médio & & Alto & & \\
\hline Patogênicos & Ato & & Médio & & Alto & & \\
\hline
\end{tabular}

Quadro 5 - Nível de importância de determinadas variáveis para a avaliação da poluição não-industrial na qualidade da água:

Fonte: UNESCO/WHO/UNEP (1992) 


\subsection{Monitoramento}

O monitoramento é um instrumento de controle na gestão ambiental. Para os recursos hídricos, é peça fundamental para o levantamento da qualidade da água no tempo e no espaço. Um bom sistema de monitoramento seria aquele que fosse seguro e representativo, em consonância com os objetivos previstos.

A COPASA vem realizando o monitoramento da água na bacia do Sistema Serra Azul (SSA), desde 1984, no entanto, os dados disponibilizados para a pesquisa compreenderam o período de 1985-1994.

O monitoramento naquele período contou com uma periodicidade mensal de coletas, cujo objetivo principal foi a caracterização das águas que aportaram o reservatório.

Sem formarem uma rede, os pontos de amostragem eram únicos para cada manancial, localizando-se todos à montante do reservatório. Essa disposição restringiu as análises espaciais e de background, representando apenas as sub-bacias como um todo. Outro fator limitante foi a não determinação das vazões no momento de amostragem. Os dados brutos estão dispostos no Anexo 2.

Dessa forma, optou-se por analisar nessa pesquisa as variaveis descritas na Deliberação COPAM 10/86/Enquadramento, cujos métodos físico-químicos utilizados pela COPASA foram descritos no Quadro 6.

\begin{tabular}{|c|c|c|}
\hline Variável & Unidade & Método de análise \\
\hline $\begin{array}{l}\text { 1. Demanda Bioquímica de } \\
\text { Oxigênio }\end{array}$ & $\mathrm{mg} / \mathrm{l}$ & Titulométrico - Diluição \\
\hline 2. Fósforo total & $\mathrm{mg} / \mathrm{l} \mathrm{P}$ & Colorimetria - Ácido ascórbico \\
\hline 3. Ferro total & $\mathrm{mg} / \mathrm{l}$ & Absorção Atômica \\
\hline 4. Ferro solúvel & $\mathrm{mg} / \mathrm{l}$ & Membrana $0,45 \mu$ - Absorção Atômica \\
\hline 5. Manganês total & $\mathrm{mg} / \mathrm{l}$ & Absorção Atômica \\
\hline 6. Nitrogênio nítrico & $\mathrm{mg} / \mathrm{l}$ & Colorimétrico - fenoldissulfônico \\
\hline 7. Nitrogênio nitroso & $\mathrm{mg} / \mathrm{l}$ & Colorimétrico - naftilamina \\
\hline 8. Oxigênio dissolvido & $\mathrm{mg} / \mathrm{l}$ & Titulométrico - Winkler \\
\hline 9. $\mathrm{pH}$ & - & Potenciométrico \\
\hline
\end{tabular}




\begin{tabular}{|l|c|c|}
\hline 10. Sólidos em suspensão & mg/l & Gravimétrico \\
\hline 11. Temperatura & ${ }^{\circ} \mathrm{C}$ & Termométrico \\
\hline 12. Turbidez & UNT & Turbidímetro \\
\hline
\end{tabular}

\subsection{Descrição sumária das variáveis de $Q A$}

\section{Coliforme fecal (CF):}

A presença de patogênicos na água ainda atormenta a saúde de muitas pessoas, principalmente aquelas desprovidas de saneamento. $\mathrm{Na}$ impossibilidade de se detectar a presença de cada um deles, optou-se por um microorganismo indicador de material fecal: Escherichia coli. Sendo de fácil deteçẫo, esses microorganismos fermentam a lactose e ainda, possuem um tempo de vida similar aos patogênicos.

Outro fator relacionado à saúde e aos coliformes seria a irrigação de hortifrutíferos, principalmente aqueles consumidos com a casca $\mathrm{e}$ produzidos próximos do solo, conforme previsto na deliberação COPAM 10/86.

Cor:

A cor da água pode ser dividida em cor verdadeira e cor aparente. A cor verdadeira se refere à influência de minerais, como o hidróxido de ferro, e de substâncias orgânicas, como os ácidos húmicos, podendo ser medida após filtração ou centrifugação. Já a cor aparente, esta é causada por componentes coloridos presentes, além da refração e reflexão da luz sobre as partículas em suspensão. As águas poluídas normalmente apresentam uma cor aparente muito forte.

A medida da cor se faz por comparação das amostras de água com uma série de diluições de cloroplatinato de potássio e cloreto de cobalto cristalino. A cor da água juntamente com a turbidez, determina a profundidade de alcance da luz que entra pela superfície. Dessa forma, ela acaba controlando a quantidade de produção primária à medida que regula a taxa de fotossíntese executada pelas algas. A unidade de medida é então chamada de unidade platina-cobalto ( $\mathrm{PPt}$ ), baseada em $1 \mathrm{mg} / \mathrm{l}$ de Pt. Águas naturais variam de $5 \mathrm{uPt}$ - águas cristalinas - até $300 \mathrm{uPt}$ - águas escuras. 


\section{Demanda Bioquímica de Oxigênio (DBO):}

Os resíduos de animais e plantas presentes nas águas naturais são matéria orgânica biodegradável. A DBO é uma maneira de se quantificar o material orgânico presente na água, sendo definida como a quantidade de oxigênio metabolizada para que os decompositores oxidem a matéria orgânica em uma forma inorgânica estável. Normalmente em águas sem poluição apresenta valores próximos de $2,0 \mathrm{mg} / \mathrm{l} \mathrm{O} 2$, e naquelas receptoras de lançamentos de esgotos os valores ficam em torno de 10,0 mg/lO2. Para se ter uma comparação, nos esgotos crus a DBO fica em torno de 600 $\mathrm{mg} / \mathrm{l} \mathrm{O} 2$, já os tratados seu valor fica entre $20-100 \mathrm{mg} / \mathrm{l} \mathrm{O} 2$.

Um aspecto a ser considerado na obtenção da DBO seria a presença de substâncias tóxicas que poderiam afetar a atividade microbiológica, conduzindo a um resultado minorado da DBO.

\section{Nitrogênio:}

O nitrogênio é encontrado naturalmente nas águas uma vez que faz parte da constituição dos organismos vivos: proteínas e material genético. No meio ambiente o nitrogênio inorgânico ocorre na forma molecular, anônio - $\mathrm{NH}_{4}{ }^{+}$, e em estados de oxidação como nitrato $-\mathrm{NO}_{3}$, e nitrito $-\mathrm{NO}_{2}$.

Nitrogênio orgânico: consiste de substâncias protéicas como aminoácidos, ácidos nucléicos e urina, e de seus produtos nas reações bioquímicas (ácidos húmicos e fúlvicos). A diferença entre a concentração de nitrogenio total e nitrogênio inorgânico dá a concentração do orgânico.Deve-se atentar para a rápida conversão do nitrogênio orgânico para amônia.

Amônia: ocorrência natural surgindo da quebra de matéria orgânica e inorgânica nitrogenada, estando presente também em efluentes inđustriais, drenagem de áreas com fertilizantes e esgotos domésticos. Em águas sem poluição, a sua concentração é pequena, ficando em $0,1 \mathrm{mg} / \mathrm{l} \mathrm{N}$ ou menos. Em águas superficiais, a amônia total é tipicamente menor que $0,2 \mathrm{mg} / \mathrm{l} \mathrm{N}$, podendo alcançar $2-3 \mathrm{mg} / \mathrm{N}$, sendo um indicador da presença de poluição orgânica caso atinja valores maiores. Em fundos de lagos e reservatórios que tenham se tornado anóxicos, é comum encontrar-me altas concentrações de amônia.

Nitrito: altas concentrações de nitrito são uma indicação de poluição industrial ou uma má condição microbiológica na água, já que o mesmo rapidamente se converteria para a forma de nitrato. Sua concentração normalmente é muito baixa, 
ficando em torno de $0,001 \mathrm{mg} / 1 \mathrm{NO}-\mathrm{N}$. A análise de ambos, nitrato e nitrito, dão uma boa condição da poluição orgânica na água. Aproximadamente tem-se que a concentração total de nitrogênio inorgânico subtraída da concentração de nitrito é igual à concentração de nitrato.

Nitrato: representando o estágio final da oxidação da matéria orgânica, é a forma mais comum de encontrar-se nitrogênio nas águas, cuja concentração raramente excede $0,1 \mathrm{mg} / \mathrm{l}$ NO3-N, podendo ser aumentada pelos esgotos domésticos e industriais, aterros, drenagem de áreas de cultivo e pastagens. Em locais com altas concentrações de nitrato na água para abastecimento público, torna-se necessária a análise da concentração do mesmo também na saída do tratamento, devido a baixa eficiência de remoção desse composto nas ETA's convencionais.

\section{Oxigênio Dissolvido (OD):}

O oxigênio dissolvido na água varia de acordo com a temperatura, salinidade, turbulência, pressão atmosférica e atividades fotossintéticas de algas e plantas. A solubilidade do oxigênio na água diminui com o aumento da temperatura e salinidade. O oxigênio é essencial para a vida aquática e em águas superficiais limpas ele possui uma concentração próxima de $10 \mathrm{mg} / \mathrm{l}$, podendo também ser expresso na forma de porcentagem de saturação (dependente da temperatura). Internamente aos corpos de água, o principal processo de consumo do oxigênio seria a respiração biológica, envolvendo aí a decomposição da matéria orgânica. Na avaliação da QA, o oxigênio é fundamental pois serve como indicador da degradação por parte da matéria orgânica - oxidação. Concentrações de $\mathrm{O}_{2}$ abaixo de $5 \mathrm{mg} / \mathrm{l}$ podem causar desequilíbrio no funcionamento da comunidade biológica e ainda, abaixo de $2 \mathrm{mg} / \mathrm{l}$, a mortandade de diversas espécies de peixes. Idealmente, o levantamento dessa variável deve ser feito in situ, evitando assim desvios por parte de reações posteriores, influência da luz e do aprisionamento de ar no recipiente de coleta.

$\mathrm{pH}$ :

O pH relaciona-se com a concentração do íon de hidrogênio e em uma dada temperatura, exprime o caráter ácido ou básico de uma solução. Em águas limpas o $\mathrm{pH}$ ficaria em torno de $6,0-8,5$. Mudanças no $\mathrm{pH}$ podem indicar contaminação por 
matéria orgânica, alterando as concentrações de oxigênio, dióxido de carbono e hidrogênio dissolvidos.

Fósforo:

Como o Nitrogênio, o Fósforo é um nutriente necessário para os organismos vivos, estando presente na água sob as formas dissolvida e particulada. Ele controla a produção primária de um corpo de água à medida que, geralmente, limita o crescimento de algas. As fontes naturais de fósforo seriam a decomposição de algumas rochas e da matéria orgânica. Artificialmente, os esgotos domésticos, principalmente aqueles ricos em detergentes; o escoamento de áreas fertilizadas e os efluentes industriais seriam as fontes responsáveis pelos distúrbios às concentrações "naturais". Nas águas superficiais naturais a concentração de fósforo varia de 0,005 0,020 mg/l PO4-P e nas águas subterrâneas, em torno de 0,020 mg/l PO4-P.

Sólidos em Suspensão:

O termo sólido é usado para designar os componentes da água que sobram após sua evaporação. Tais componentes variam no tamanho entre $10 \mathrm{~nm}$ até $0,1 \mathrm{~mm}$; entretanto, é aceita a definição de que a matéria suspensa seria aquela retida na málha de $0,45 \mu \mathrm{m}$ de diâmetro. Dessa forma, a variável Sólidos em Suspensão (SS), corresponde à parte não filtrável, e Sólidos Dissolvidos Totais (SDT) seriam a parte filtrável. Juntas, essas variáveis quantificam a matéria que está sendo transportada em dado momento e seção.

Turbidez e Transparência:

A transparência e a turbidez da água dependem diretamente do tipo e da concentração de matéria em suspensão. Ambas podem variar sazonalmente devido a produção biológica e a quantidade de solo transportado pelo escoamento superficial. Normalmente, a matéria em suspensão consiste de silte, argila, compostos orgânicos, partículas finas orgânicas e inorgânicas, plâncton e outros microorganismos.

A turbidez resulta do desvio e absorção da luz incidente pelas partículas e deve ser medida em campo de forma a evitar mudanças, como no $\mathrm{pH}$.

A transparência seria o limite de visibilidade na água. Ela é medida em campo através do disco de Secchi, principalmente em lagos e reservatórios, de forma a se estimar a atividade biológica. 
Temperatura:

A temperatura das águas superficiais é influenciada pela altitude, latitude, sazonalidade e mesmo pela circulação de ar, variando entre 0-30\%. Nas águas subterrâneas superiores a temperatura tende a ser próxima a da superfície, entretanto, em aquíferos profundos, tende a ser mais alta, dado o gradiente termal do planeta. Essa variável afeta os processos, físicos, químicos e biológicos dos corpos de água e dessa forma, a concentração de diversas outras variáveis. Com o aumento da temperatura, a taxa de reações químicas geralmente aumenta, sendo acompanhada do aumento da evaporação e volatilização de substâncias presentes na água. O aumento da temperatura provoca a diminuição da solubilidade de gases na água, como oxigênio, nitrogênio, metano e gás carbônico, entre outros. O aumento da temperatura também influencia no metabolismo dos organismos aquáticos, incrementando, por exemplo, as taxas de respiração que por sua vez conduzem a um maior consumo de oxigênio dissolvido e a uma maior decomposição de matéria orgânica.

Ferro e Manganês:

Em geral essas variáveis não representam problemas para a saúde humana, entretanto, a presença desses cátions em quantidades suficientes, tem causado problemas para o abastecimento público de água: o ferro por sua propriedade organoléptica e o manganês, por escurecer a água. Ambos ocorrem nos solos e minerais, principalmente na região do Quadrilátero Ferrífero, que é onde se insere a área de estudo, de forma insolível: óxido férrico (pirita), carbonato ferroso (siderita), dióxido de manganês. Quando em solução, segundo SAWYER (1994), principalmente em águas com oxigênio dissolvido, os compostos de Fe3 e Mn4 continuariam insolúveis, passando para as formas solúveis, Fe2 e Mn2, em condições anaeróbicas ou mesmo, devido a certas bactérias que os converteriam durante seu metabolismo. 


\section{Uso do Solo}

O estudo do uso e ocupação do solo se torna fundamental para a compreensão do comportamento das variáveis de qualidade e desta forma, orientar as ações de gerenciamento dos recursos hídricos. Assim, a estimativa da evolução do uso do solo deve respeitar as sub-bacias representadas pelo monitoramento da água, que foram: Curralinho, Diogo, Estiva, Jacu, Potreiro e Serra Azul.

Os trabalhos realizados pela COPASA em 1983 e 1998, baseados em levantamentos aéreos de 1977 e 1989, respectivamente, caracterizaram um momento anterior ao monitoramento e outro intermediário a cle.

\subsection{Ano 1977}

Os estudos para a operação do reservatório contaram com um levantamento do uso e ocupação do solo baseado no levantamento aerofotogramétrico realizado em 1977 na escala 1:40.000. Em COPASA (1983), tem-se o resumo desse trabalho conforme o quadro 7.

\begin{tabular}{|l|c|c|}
\hline TIPO DE COBERTURA & ÁREA (Km2) & \% ÁREA TOTAL \\
\hline Campo cerrado & 70,0 & 26,3 \\
\hline Cerrado & 48,4 & 18,2 \\
\hline Solos expostos & 42,5 & 16,0 \\
\hline Áreas agrícolas & 28,3 & 10,6 \\
\hline Campo limpo ou pastagem & 24,1 & 9,1 \\
\hline Mata densa & 16,7 & 6,3 \\
\hline Reflorestamento & 14,9 & 5,6 \\
\hline Cerradão & 14,0 & 5,3 \\
\hline Mata rala & 5,6 & 2,1 \\
\hline Áreas & 1,1 & 0,4 \\
construídas & & 0,1 \\
\hline Açudes e represas & 0,3 & $\mathbf{1 0 0}$ \\
\hline Totanas & $\mathbf{2 6 5 , 9}$ & \\
\hline
\end{tabular}


Quadro 7 - Resumo dlo uso do solo na bacia Serra Azul em 1977.

Descrição da legenda utilizada para o levantamento de 1977:

Florestas: a bacia localiza-se em uma área de transição entre o cerrado e a floresta mesófila semidecídua. A mata densa corresponde à mata ciliar, podendo formar mata de galeria ao longo dos córregos. A mata rala se apresenta de maneira similar a densa mas com menor densidade de árvores.

Cerrado: o cerrado se caracteriza como um tipo vegetacional de pequeno porte, com árvores de casca grossa e retorcida. Nesse trabalho foram identificados três tipos de cerrado: campo cerrado: espaço grande entre os elementos arbóreos, predominando entre eles gramíneas; cerrado: arvoretas maiores e mais próximas que as anteriores; cerradão: transição entre cerrado e floresta, o mais denso de todos.

Reflorestamento: eucaliptos mais presentes no Córrego do Tijuco.

Solo exposto: desmatamentos, mineração, afloramentos, erosão: voçorocas e ravinamentos.

Campo limpo e pastagens: locais com vegetação natural ou não, compostas predominantemente de gramíneas e de outras plantas destinadas à alimentação bovina.

Terra agrícola: solo agrícola plantado.

Áreas urbanas/construídas: áreas urbanas, loteamentos e construções diversas.

\subsection{Ano 1989}

O quadro 8 apresenta o resumo do levantamento do uso e ocupação do solo realizado pela COPASA e pelo Centro Tecnológico de Minas Gerais - CETEC (1998), através da interpretação de fotografias obtidas em vôo de julho/89;

\begin{tabular}{|l|l|l|}
\hline $\begin{array}{c}\text { Classes de Uso do solo e } \\
\text { cobertura vegetal }\end{array}$ & \multicolumn{1}{|c|}{ Área $\left(\mathbf{k m}^{2}\right)$} & $\%$ \\
\hline $\begin{array}{l}\text { - Agropecuária } \\
\text { Pasto, Pasto sujo, Área } \\
\text { cultivada. }\end{array}$ & 139,06 & 53,0 \\
\hline $\begin{array}{l}\text { - Cerrado } \\
\text { Cerrado, Campo cemado. }\end{array}$ & 57,67 & 21,9 \\
\hline
\end{tabular}




\begin{tabular}{|c|c|c|}
\hline $\begin{array}{l}\text { - Campo rupestre } \\
\text { Campo rupestre }\end{array}$ & 1,34 & 0,5 \\
\hline $\begin{array}{l}\text { - Floresta Nativa } \\
\text { Floresta Mesófila Floresta } \\
\text { Galerial Associação } \\
\text { floresta/cerrado }\end{array}$ & 34,39 & 13,1 \\
\hline $\begin{array}{l}\text { Floresta Plantada } \\
\text { Eucalyptus sp., Pinus sp. }\end{array}$ & 4,34 & 1,6 \\
\hline $\begin{array}{lr}\text { - Outros Usos } & \\
\text { Granja, } & \text { Chácara, } \\
\text { Loteamento, } & \text { Perímetro } \\
\text { urbano, Solo } & \text { exposto, } \\
\text { estradas. } & \\
\end{array}$ & 14,6 & 5,6 \\
\hline - Mineração & 2,37 & 0,9 \\
\hline -Reservatório & 8,90 & 3,4 \\
\hline TOTAL & 262,67 & 100 \\
\hline
\end{tabular}

Quadro 8 - Resumo do uso do solo na bacia Serma Azul em 1989. Fonte: COPASA (1998).

Os tipos vegetacionais nativos encontrados na bacia do Serra Azul, em COPASA (1998), form:

- Florestas de Galeria: formações florestais que contêm elementos das florestas atlântica e amazônica além de outros próprios. Possuem grande número de mesófitos herbáceos, macrófilos e epífitas. O estrato arbóreo atinge até $20 \mathrm{~m}$.

- Florestas mesófilas: são florestas estacionais decíduas ou semi-deciduas cuja florística e estrutura se condicionam á estacionalidade climática. Possuem fanerofitos com gemas foliares protegidas da seca, tendo folhas adultas esclerófitas ou membranosas decíduas. Nelas ocorrem gêneros amazônicos de ampla distribuição como Astronium sp., Tabebaia sp. e grande numero de leguminosas.

- Cerrado: formação campestre, bioestratificada, com estrato herbáceo dominado por gramíneas. Nessa formação incluem-se os quatro tipos físionômicos principais como campo sujo, campo limpo, campo cerrado e cerrado "sensu stricto" (típico). Cerca de 40 a $50 \%$ das espécies que ocorrem no cerrado típico participam dos diversos tipos fisionômicos em múltiplas combinações.

- Campo rupestre: referem-se a um conjunto de grupos vegetacionais influenciados pelas condições do relevo, microclima e substrato. Ocorrem em altitudes acima de $900 \mathrm{~m}$, principalmente onde são encontrados cerrados, 
matas secas (mesófilas) e matas de galeria, ao longo da cadeia do Espinhaço em MG e BA, com disjunções nos estados de GO, TO e MT. Como estão associadas à redução da profundidade dos solos, suas espécies vegetais crescem sobre pedras, rochas, solos pedregosos ou arenosos, sendo a comunidade herbácea dominada por gramíneas, ciperáceas, eriocauláceas e velosiáceas. A florística da comunidade arbustivo/arbórea é composta principalmente por compostas (Eremanthus sp.), leguminosas (Mimosa sp. e Dalbergia sp.), euforbiáceas (Cróton sp.). Estas regiões são mais frias durante a noite e a neblina que se forma fornece a umidade que é absorvida por um tecido especial, o velame, em muitas espécies de velosiáceas (canela-deema).

O Quadro 9 apresenta as classes de uso utilizadas, bem como, os resultados encontrados para cada sub-bacia. 


\begin{tabular}{|c|c|c|c|c|c|c|c|c|}
\hline \multicolumn{9}{|l|}{ Uso do Solo (km2): } \\
\hline & 1977 & Curralinho & Diogo & Estiva & Jacu & Potreiro & Serra Azul & Sub-totais: \\
\hline \multirow{3}{*}{ Mata nativa } & Mata densa & 0,504 & 1,827 & 2,142 & 0,441 & 0,126 & 13,356 & 18,396 \\
\hline & Mata rala & 0,378 & 1,134 & 0,693 & 0 & 0 & 1,701 & 3,906 \\
\hline & Cerradäo & 0,063 & 5,607 & 0,882 & 0 & 0 & 6,237 & 12,789 \\
\hline & Sub-totais: & 0,945 & 8,568 & 3.717 & 0,441 & 0,126 & 21,294 & 35,091 \\
\hline \multirow{3}{*}{ Cerracio } & Cerrado & 3,906 & 5,166 & 4,473 & 2,772 & 0,189 & 27,342 & 43,848 \\
\hline & Campo cerrado & 5,418 & 6,489 & 6,615 & 3,528 & 1,953 & 29,421 & 53,424 \\
\hline & Stib-totais: & 9,324 & 11,655 & 11,088 & 6,3 & 2,142 & 56,763 & 97,272 \\
\hline Reflorestamento & Reflorestamento & 1,071 & 4,158 & 2,142 & 0,315 & 0,315 & 2,646 & 10,647 \\
\hline \multirow{3}{*}{ Agropecuária } & Campo limpo/pasto & 1,26 & 2,205 & 4,536 & 0,252 & 0,126 & 9,954 & 18,333 \\
\hline & Areas agricolas & 1,26 & 4,977 & 7,245 & 0,441 & 0,315 & 11,466 & 25,704 \\
\hline & Sub-totais: & 2,52 & 7,182 & 11,781 & 0,693 & 0,441 & 21,42 & 44,037 \\
\hline \multirow{6}{*}{ Urbanização } & Áreas construidas & 0,189 & 0,315 & 0,378 & 0 & 0 & 0,315 & 1,197 \\
\hline & Solo exposto/mineração & 0,819 & 1,638 & 3,843 & 1,26 & 0,315 & 18,774 & 26,649 \\
\hline & Desmatamento & 0,126 & 0,567 & 0,126 & 0,189 & 0,063 & 0,882 & 1,953 \\
\hline & Sub-totais: & 1,134 & 2,52 & 4,347 & 1,449 & 0,378 & 19,971 & 29,799 \\
\hline & Area total: & 14,994 & 34,083 & 33,075 & 9,198 & 3,402 & 122,094 & 216,846 \\
\hline & 1989 & Curralinho & Diogo & Estiva & Jacu & Potreiro & Serra Azud & Sulb-totais: \\
\hline \multirow{3}{*}{ Mata nativa } & Floresta de galeria & 0 & 0,33 & 0 & 0 & 0 & 1,01 & 1,34 \\
\hline & Floresta mesófila & 1,49 & 3,04 & 0,81 & 0,2 & 0,29 & 19,11 & 24,94 \\
\hline & Floresta mesófila + cerrado & 0 & 0,88 & 0 & 0 & 0 & 0 & 0,88 \\
\hline & Sub-totais: & 1,49 & 4,25 & 0,81 & 0,2 & 0,29 & 20,12 & 27,16 \\
\hline \multirow{3}{*}{ Cerrado } & Cerrado & 2,23 & 4,87 & 3,43 & 3,16 & 1,26 & 17,88 & 32,83 \\
\hline & Campo cerrado & 0 & 0,07 & 1,99 & 0,32 & 0 & 1,7 & 4,08 \\
\hline & Campo rupestre & 0 & 0.88 & 0,46 & 0 & 0 & $\underline{0}$ & 1,34 \\
\hline & Sub-totais: & 2,23 & 5,82 & 5,88 & 3,48 & 1,26 & 19,58 & 38,25 \\
\hline Reflorestamento & Floresta Plantada & 0,17 & 0,86 & 0,51 & 0,62 & 0,12 & 0,12 & 2,4 \\
\hline \multirow{3}{*}{ Agropecuária } & Pasto & 6.57 & 11,9 & 15,26 & 2,28 & 0,78 & 64,57 & 101,36 \\
\hline & Pasto sujo & 0,93 & 3,81 & 1,64 & 0,99 & 0,29 & 4,72 & 12,38 \\
\hline & Area cultivada & 2,01 & 5,14 & 3,76 & 0.47 & 0,11 & 10,79 & 22,28 \\
\hline & Sub-totais: & 9,51 & 20,85 & 20,66 & 3,74 & 1,18 & 80,08 & 136,02 \\
\hline \multirow{6}{*}{ Urbanização } & Perímetro urbano & 0 & 0 & 0 & 0 & 0 & 0,44 & 0,44 \\
\hline & Loteamento & 1,6 & 0 & 0,83 & 1,04 & 0,43 & 0,09 & 3,99 \\
\hline & Chácaras & 0 & 0,74 & 2,14 & 0 & 0 & 0,03 & 2,91 \\
\hline & Granjas & 0 & 0,07 & 0,42 & 0 & 0 & 0 & 0,49 \\
\hline & Estradas & 0,02 & 0,19 & 1,05 & 0 & 0,02 & 1,02 & 2,3 \\
\hline & Mineracão & 0 & 0,2 & 0,49 & 0 & r & 1.68 & 2,37 \\
\hline \multirow{3}{*}{\multicolumn{2}{|c|}{$\begin{array}{l}\text { Area total: } \\
\text { Fonte: COPASA (1983) e (1998). }\end{array}$}} & 1,62 & 1,2 & 4,93 & 1,04 & 0,45 & 3,26 & 12,5 \\
\hline & & 15,02 & 32,98 & 32,79 & 9,08 & 3,3 & 123,16 & 216,33 \\
\hline & & & & & & & & \\
\hline
\end{tabular}

Quadro 9-Resumo agrupado do uso do solo de 1977 e 1989. Fonte: COPASA (1983) e (1989). 


\section{Análises pertinentes}

\section{I Drenagem e Geologia}

Em um cenário sem interferência humana, quando ocorre precipitação suficiente, a enxurrada arrasta material proveniente principalmente dos solos, rochas e vegetação. A interação da água com cada um deles mais a energia mecânica envolvida, ajudam a modelar no relevo esculturações que refletem as preferências para o escoamento superficial. Assim, com o passar do tempo, e a permanente interação das vertentes com os rios, imagina-se que as superfícies, mesmo em áreas diferentes, estejam ajustadas ao regime hidrológico, resultando o relevo de então.

$\mathrm{Na}$ hidrologia e geomorfologia, os principais índices que consideram a drenagem e a energia na caracterização do escoamento na bacia hidrográfica são a

\section{Densidade de drenagem e Índice de rugosidade.}

A densidade de drenagem (Dd), relaciona o comprimento (L), de todos os canais de escoamento com a área da bacia (A).

O índice de rugosidade (Ir), seria o produto da amplitude altimétrica $(\mathrm{H})$, ou seja, da diferença entre a cota da nascente e a da foz, pela densidade de drenagem (Dd). Nesse caso, a cota da foz seria a cota do ponto de monitoramento.

Eles refletem o potencial da bacia em escoar, através das drenagens, matéria, ainda que poluente, fornecida pelas vertentes.

A partir da análise e digitalização do mapeamento realizado em 1981 pelo Instituto de Geociências Aplicadas (IGA/MG), folhas Azurita, Mateus Leme, Igarapé, Itatiaiuçu, Itaúna e Juatuba, todas na escala 1:25000, as sub-bacias foram comparadas quanto à densidade de drenagem e à ragosidade, conforme Tabela 3 .

\begin{tabular}{|c|c|c|c|c|c|c|c|c|}
\hline $\begin{array}{c}\text { Nome sub- } \\
\text { bacia }\end{array}$ & Área (km2) & $\begin{array}{l}\text { Perímetro } \\
(\mathrm{km})\end{array}$ & $\begin{array}{c}\text { Altitude } \\
\text { nacente } \\
\text { (m) }\end{array}$ & $\begin{array}{l}\text { Altitude } \\
\text { foz (m) }\end{array}$ & $\begin{array}{l}\text { Comprimento } \\
\text { da bacia }(\mathrm{km})\end{array}$ & $\begin{array}{c}\text { Comprimento } \\
\text { total dos canais } \\
-L(\mathrm{~km})\end{array}$ & $\begin{array}{c}\text { Densiciacte } \\
\text { de } \\
\text { drenagem: } \\
\text { Dd=L/A } \\
(\mathrm{km} / \mathrm{km} 2)\end{array}$ & $\begin{array}{l}\text { Índice de } \\
\text { rugosidade: } \\
\text { |r=H.Dd }\end{array}$ \\
\hline Curralinho & 14,674 & 22,442 & 850,0 & 770,0 & 4.491 & 23,541 & 1,604 & 0,128 \\
\hline Diogo & 30,576 & 26,891 & 1250,0 & 760,0 & 8.855 & 48,137 & 1,574 & 0.771 \\
\hline Estiva & 30,833 & 24,306 & 12000 & 770,0 & 79916 & 43,819 & 1,421 & 0.611 \\
\hline Jacu & 8,891 & 14,309 & 1000,0 & 765,0 & 5.801 & 18.373 & 2,066 & 0.486 \\
\hline Potreiro & 2,812 & 8,348 & 825,0 & 770,0 & 2,490 & 4.823 & 1,715 & 0.094 \\
\hline Serra Azul & 123,037 & 55,784 & 1100,0 & 765,0 & 17.317 & 274,909 & 2,234 & 0,749 \\
\hline
\end{tabular}

Tabela 3 - Características morlométricas das sub-bacias. 
A Figura 5 mostra a rede de drenagem da região. Se comparada ao mapa geológico, Figura 3, percebe-se a resistência que os diferentes substratos impuseram ao escoamento superficial. Nas encostas da Serra Azul, área com rochás de granulometria mais grosseira, ocorre menor densidade de drenagem, caracterizada por segmentos bifurcados inicialmente, mas que logo se alinham em ligeira concordânciá com a direção NE. Em posição oposta a Serra Azul, a outra grande vertente da bacia se assenta, basicamente, sobre gnaisses, responsáveis pela formação de uma rede dendrítrica e mais densa de canais.

O Gráfico 9 mostra que a submacia do Serra Azul apresenta a maior densidade de drenagem, seguida pela área do Jacu. Em Diogo encontra-se o maior índice de rugosidade, influenciado pela sua amplitude altimétrica. Christofoletti (1980), alerta para a possibilidade de haver bacias com mesma rugosidade e diferentes densidades de drenagem, indicando, nesse caso, a presença de relevo mais íngrime.

Assim sendo, as sub-bacias que se apresentaram mais semelhantes quanto à quantidade de drenagens por unidade de área e à amplitude do relevo foram: Curralinho e Potreiro, Diogo e Estiva, Jacu e Serra Azul. Espera-se que para um mesmo evento de precipitação, a influência do relevo na recepção da chuva seja próxima entre esses pares de bacias. Quanto à geologia, a sub-bacia do Serra Azul se apresenta mais diferenciada que as demais, limitando sua associação com a área do Jacu.

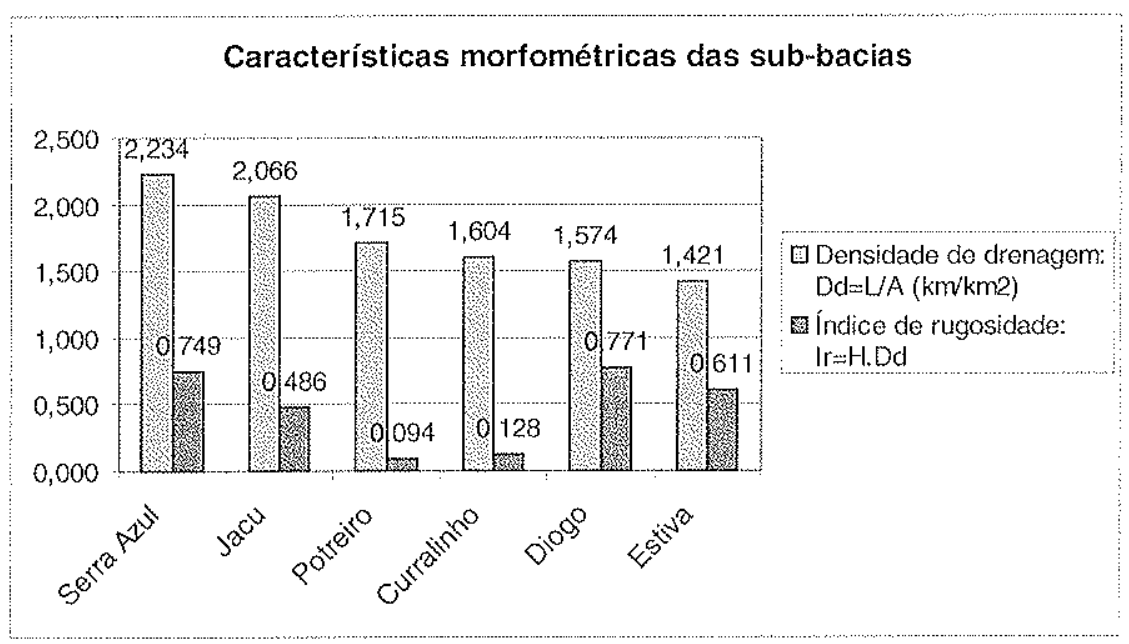

Gráficos 9 - Características morlométricas das sub-bacias. 
Os trabalhos anteriores tiveram suas legendas agrupadas de forma a caracterizar os tipos de uso do solo. Essa caracterização partiu das sub-bacias representadas pelos dados disponibilizados de QA, não envolvendo toda a bacia. O agrupamento torna possível uma comparação mais bem definida dos tipos de uso do solo no tempo, além de dirimir as diferenças entre as legendas anteriores. Assim sendo, foram estabelecidos os seguintes grupos de uso do solo:

- Vegetação natural: representa os locais sem interferência ou com discreta interferência antrópica. Agrupa os itens definidos anteriormente como floresta de galeria, floresta mesófila, mata densa, mata rala, cerradão, cerrado e campo cerrado.

- Agropecuária: de maneira geral, agrupa os locais cujas principais interferências seriam a produção agrícola e o desenvolvimento da pecuária. Envolve os itens pasto, pasto sujo, campo limpo, áreas agrícolas, incluindo os reflorestamentos e os desmatamentos.

- urbanização: inclui as interferências cuja implantação exigiu a instalação de uma infra-estrutura mais específica e a consequiente eliminação da proteção vegetal. Envolve as áreas urbanas, loteamentos, chácaras, granjas, estradas, mineração e ainda, os afloramentos e os solos expostos.

Nesse sentido, os estudos referentes ao uso do solo em 1977 e 1989, Quadro 9, ao definirem a área de cada sub-bacia, excetuando-se a do Serra Azul, extrapolaram os pontos de amostragem da qualidade da água, estendendo se até aos estuários de cada manancial. Tal fato aumentou a área de cada sub-bacia ao incluir solos localizados na reserva que envolve o reservatório e que, dessa forma, não contribuíam para os referidos pontos de monitoramento. A partir dessa constatação, aquelas extrapolações foram estimadas e os resultados corrigidos, conforme o

\section{Quadro 10.}




\begin{tabular}{|c|c|c|c|c|c|c|c|}
\hline 1977 & Curratinho & Diogo & Estiva & Jacu & Potreiro & Serra Azul & Sub-totais: \\
\hline Vogetaçäo nativa & 1026,9 & 2022,3 & 1480,5 & 674,1 & 226,8 & $7805, \%$ & 13236,3 \\
\hline Agropecuária & 371,7 & 1190,7 & 1404,9 & 119,7 & 81,9 & 2494,8 & 5663,7 \\
\hline Urbaniæaçäo & 100,8 & 195,3 & 422,1 & 126 & 31,5 & 1908,9 & 2784,6 \\
\hline Area total (ha) & 1499,4 & 3408,3 & 3307,5 & 919,8 & 340.2 & 12209,4 & 21684,6 \\
\hline 1989 & Curralinho & Diogo & Estiva & Jacu & Potreiro & Serra Azul & Sub-totais: \\
\hline Vegelação nativa & 372 & 1007 & 669 & 368 & 155 & 3970 & 6541 \\
\hline Agropecuária & 968 & 2171 & 2117 & 436 & 130 & 8020 & 13842 \\
\hline Urbanização & 162 & 120 & 493 & 104 & 45 & 326 & 1250 \\
\hline Área total (ha) & 1502 & 3298 & 3279 & 908 & 330 & 12316 & 21633 \\
\hline
\end{tabular}

\begin{tabular}{|c|c|c|c|c|c|c|c|}
\hline 1977 & Curralinho & Diogo & Estiva & Jacu & Potreiro & Serra Azul & Sub-totais: \\
\hline Vegetação nativa & 1013,69 & 1860,5 & 1430,28 & 643,4 & 167,8 & 7805,7 & 12921,34 \\
\hline Agropecuária & 371,7 & $100+, 4$ & 1291,33 & 119,7 & 81,9 & 2494,8 & 5360,8 \\
\hline Urbanizaçào & 100,8 & 195,3 & 347,71 & 126 & 31,5 & 1908,9 & 2710,21 \\
\hline Area total (ha) & 1486,19 & 3057,1 & 3069,32 & 889,7 & 281,2 & 12209,4 & 20992,35 \\
\hline 1989 & Curralinho & Diogo & Estiva & Jacu & Potreiro & Serra Azul & Sub-totais: \\
\hline Vegetaçäo nativa & 356,11 & 895,95 & 614,02 & 349,01 & 106,2 & 3970 & 6291,29 \\
\hline Agropecuátia & 968 & 2041,1 & 2027,92 & 436 & 130 & 8020 & 13622,97 \\
\hline Urbanizaçăo & 162 & 120 & 427,52 & 104 & 45 & 326 & 1184,52 \\
\hline Area total (ha) & 1486,11 & $305 \%$ & 3069,46 & 889,01 & 281,2 & 12310 & 21098,78 \\
\hline
\end{tabular}

Quadro 10 - Uso do solo 1977 e 1989: correção dáa área.

Essa correção partiu da estimação da nova jusante de cada sub-bacia e do percentual de cada grupo de uso do solo situados naquelas porções. Posteriormente, determinou-se a diferença entre as áreas atuais e as anteriormente estimadas, e sobre cada diferença aplicaram-se os respectivos percentuais de ocupação de cada porção. Nesse ajuste, destaca-se a queda no item urbanização para a sub-bacia do Estiva. Isso se deveu ao fato do bairro Fazenda Solar, local de expansão urbana, não estar coberto pelo monitoramento da qualidade da água.

Os Gráfícos 10 e 11, totalizam o uso do solo da área coberta pelo monitoramento nos períodos de 1977 e 1989 , respectivamente. 

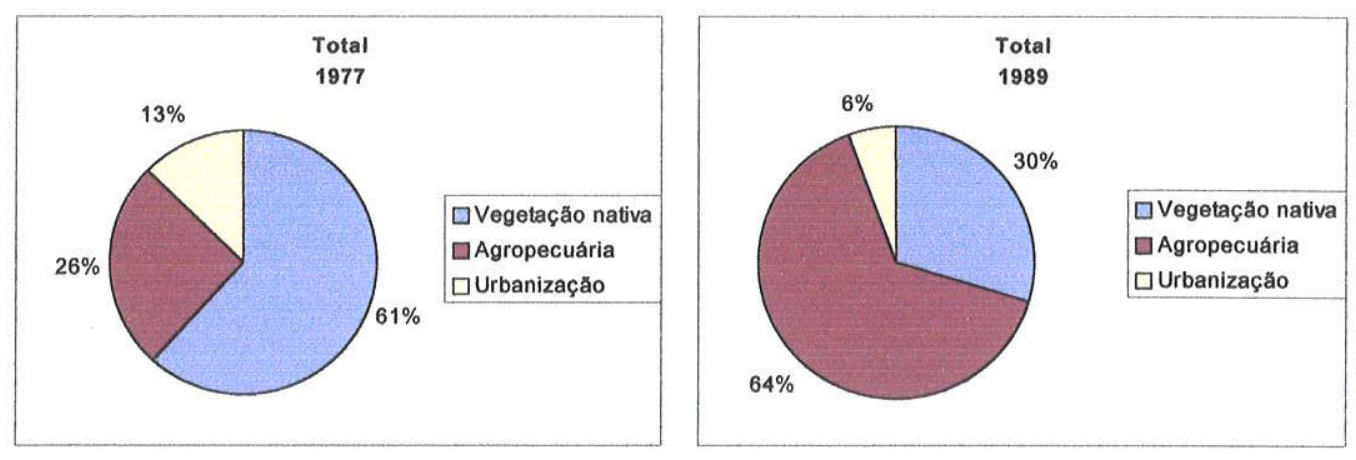

Gráficos 10 e 11 - Percentual de ocupação dos grupos de uso do solo em 1977 e 1989

\subsection{O uso do solo: 1999}

A análise mais recente do uso do solo, ou seja, feita nesse trabalho, contou com a imagem de satélite Landsat 7 ETM+ de 7 de agosto de 1999, disponibilizada pelo Instituto Nacional de Pesquisas Espaciais (INPE), e fotografias aéreas obtidas em outubro de 1998 na escala 1:30.000, pela empresa Esteio, contratada pela COPASA. Partiu da digitalização e georreferenciamento das cartas do IGA de 1981, as mesmas de onde foram levantadas as drenagens. A próxima etapa contou com a montagem do mosaico, englobando a área na qual se assentava a bacia, e finalmente, a digitalização do limite da área, as sub-bacias e as drenagens.

Posteriormente, a composição RGB das bandas 4, 5 e 7, respectivamente, Figura 6, obteve melhores resultados para a identificar dos diferentes grupos de uso do solo, cuja interpretação juntamente com as fotografias, permitiu identificar os seguintes comportamentos espectrais:

- vegetação menos densa (cerrado) para a mais densa (galeria): parte do verde acinzentado para o vermelho mais intenso.

- areas urbanas: tons de azul e vermelho, tendendo a lilás

- água: prevalece o preto

- afloramentos de itabirito e canga: prevalece a cor azul, bem como os solos expostos.

- pastagens: prevalece o verde claro, ocorrendo aumento de tom vermelho claro quando mais sujas, principalmente nas proximidades das áreas de vegetação mais densa. 
- áreas agrícolas apresentaram tons bastante variados. Pode-se dizer que para as áreas plantadas, prevaleceu a cor verde, alcançando cores mais vermelhas para as culturas mais perenes, como o café. Para as áreas em preparo predominaram tons de lilás semelhantes aos da área urbana.

Definidos os diferentes usos, os mesmos foram digitalizados em tela, conforme Figura 7, representando o estado mais atual na região de estudo. A área de cada polígono foi calculada e agrupada para cada sub-bacia na Tabela 4. Para o item Estradas, utilizou-se o resultado de 1989.

A Tabela 5 apresenta os valores encontrados na Tabela 4, agrupados e dispostos no Gráfico 12.

\begin{tabular}{|c|c|c|c|c|c|c|c|}
\hline 1999 & Curralinho & Diogo & Estiva & Jacu & Potreiro & Serra Azul & total \\
\hline Área (ha) & 1486,2 & 3057,1 & 3069,5 & 889,1 & 281,2 & 12310,6 & 21093,7 \\
\hline Vegetação nativa & 134,3 & 730,4 & 473,2 & 272,9 & 21,3 & 3222,9 & 4845,5 \\
\hline Reflorestamento & & 54,8 & & & & 12,6 & 67,4 \\
\hline Agropecuária & 1136,3 & 2096,5 & 2143,1 & 447,3 & 182,6 & 8677,8 & 14913,6 \\
\hline Urbana & 213,6 & 91,7 & 190,0 & 168,9 & 75,3 & 72,3 & 811,9 \\
\hline Solo exposto & & 64,6 & 88,2 & & & 223,0 & 375,9 \\
\hline BR381 & & & 70,0 & & & & 70,0 \\
\hline Estradas (1989) & 2,0 & 19,0 & 105,0 & & 2,0 & 102,0 & \\
\hline Totais (ha) & 1486,2 & 3057,1 & 3069,5 & 889,1 & 281,2 & 12310,6 & 21084,2 \\
\hline
\end{tabular}

Tabela 4 - Uso do solo em 1999.

\begin{tabular}{|c|c|c|c|c|c|c|c|}
\hline 1999 & Curralinho & Diogo & Estiva & Jacu & Potreiro & Serra Azul & Sub-totais: \\
\hline Vegetação nativa & 134,3 & 730,4 & 473,2 & 272,9 & 21,3 & 3222,9 & 4845,5 \\
\hline Agropecuária & 1136,3 & 2151,3 & 2143,1 & 447,3 & 182,6 & 8690,4 & 14981,0 \\
\hline urbanização & 215,6 & 175,3 & 453,2 & 168,9 & 77,3 & 397,3 & 1257,7 \\
\hline Area total (ha) & 1486.2 & 3057.1 & 3069.5 & 889.1 & 281,2 & 12310,6 & 21084,2 \\
\hline
\end{tabular}

Tabela 5 - Uso do solo em 1999: agrupado.

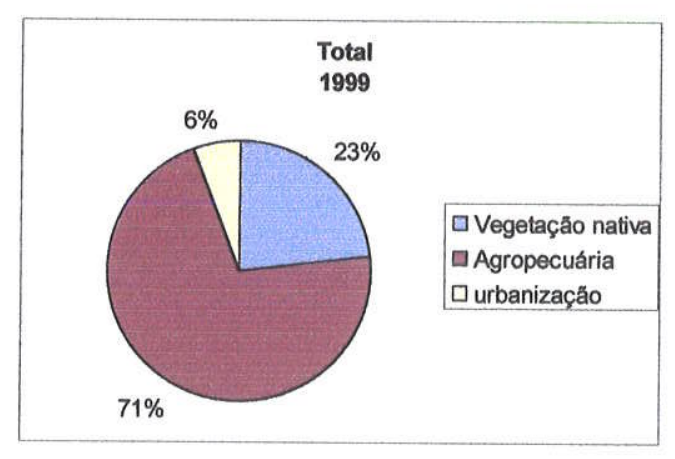

Gráfico 12 - Percentual de ocupação dos grupos de uso do solo em 1999. 


\subsection{Evolução do uso do solo}

De maneira geral, os Gráficos 10-11-12 mostram a evolução do uso do solo no tempo, marcada pelo aumento na área ocupada por Agropecuária em detrimento da Vegetação nativa. O grupo Urbanização caiu de 13\% em 1977, para 6\% da área total em 1989 e depois se manteve estável. Na verdade ocorreu que no estudo de 1977, as áreas de mineração, afloramentos, solos expostos e principalmente, solos agrícolas desnudos, foram reunidas e acabaram por elevar o percentual de Urbanização naquele período. Os Gráfïcos 13 a 18, ilustram a evolução dos três grupos principais de uso do solo nas sub-bacias.

O par Serra Azul e Jacu, representado pelos Gráficos 13 e 14, respectivamente, apresentou aumento na área de Agropecuária e queda na Vegetação nativa. A urbanização se manteve em 3\% do território do Serra Azul e teve aumento de $12 \%$ para $19 \%$ na sub-bacia do Jacu, refletindo sua tendência a urbanização dada sua proximidade ao distrito de Mateus Leme.

Estiva e Diogo apresentaram o mesmo comportamento de expansão da Agropecuária, entretanto, esse último apresenta uma menor degradação da vegetação nativa, com $24 \%$ da área total. Em ambas sub-bacias, a Urbanização cresceu entre 1 -. $2 \%$, conforme os Gráfico 15 e 16, respectivamente.

As sub-bacias Potreiro e Curralinho apresentam o menor percentual de Vegetação nativa, em torno de 8\%. Através dos Gráficos 17 e 18, percebe-se que elas tiveram esse grupo diminuído ao longo do tempo, diferentemente da Urbanização, que atingiu $28 \%$ da área em Potreiro e 15\% em Curralinho, e da Agropecuária, com $64 \%$ e $76 \%$ respectivamente.

As diferenças entre a ocupação da bacia atribuídas aos intervalos 1977-1989 e 1989-1994, mostraram que tal processo se deu de maneira heterogênea, tanto no espaço quanto no tempo. A Tabela 6 apresenta a Taxa de variação do uso do solo nos dois intervalos de tempo para as sub-bacias. 
Taxa de variação do uso do solo (ha/ano):

1977-1989 Curralinho Potreiro Diogo Estiva Jacu Serra Azul Total

$\begin{array}{llllllll}\text { Vegetação nativa } & -54,8 & -5,1 & -80,4 & -68,0 & -24,5 & -319,6 & -552,5\end{array}$

$\begin{array}{llllllll}\text { Agropecuária } & 49,7 & 4,0 & 86,6 & 61,4 & 26,4 & 460,4 & 688,5\end{array}$

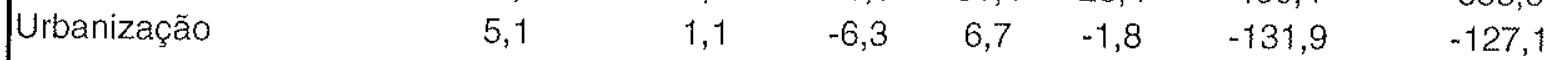

Taxa de variação do uso do solo (ha/ano):

1989-1994 Curralinho Potreiro Diogo Estiva Jacu Serra Azul Total

$\begin{array}{llllllll}\text { Vegetação nativa } & -22,2 & -8,5 & -16,6 & -14,1 & -7,6 & -74,7 & -144,6\end{array}$

$\begin{array}{llllllll}\text { Agropecuária } & 16,8 & 5,3 & 11,0 & 11,5 & 1,1 & 67,0 & 135,8\end{array}$

$\begin{array}{llllllll}\text { Urbanização } & 5,4 & 3,2 & 5,5 & 2,6 & 6,5 & 7,1 & 7,3\end{array}$

Tabela 6 - Taxa de variação do uso do solo.

A Taxa de variação do uso do solo seria apenas uma referência linear de uma ocupação que na realidade foi não-linear. Ela ilustra, no caso, a moderação ocorrida na ocupação de áreas nativas, principalmente em Serra Azul, e uma incipiente urbanização em toda a bacia. Mostra também que Potreiro foi a única sub-bacia a ter aumentado a taxa, neste caso, de desocupação da Vegetação Nativa.

\subsection{Dinâmica da qualidade da água}

A análise dos dados brutos de QA disponibilizados pela COPASA, partiu das seguintes hipóteses:

- as normas previstas de coleta e conservação das amostras, quando foi o caso, foram seguidas,

- o laboratório cumpriu os procedimentos de análise corretamente,

- as coletas foram efetuadas sempre no mesmo ponto ao longo dos anos,

- os resultados foram transferidos do laboratório, digitados e armazenados em arquivos, no caso DBASE, de maneira igualmente correta.

A partir daí, procedeu-se à análise da distribuição das variáveis abordadas na resolução 10/86 do COPAM. Como já era prevista em estudos da qualidade da água, a maioria das variáveis apresentaram distribuição assimétrica. Assim sendo, optou-se por inferir todas as variáveis brutas através das medidas de tendência nãoparamétricas. 

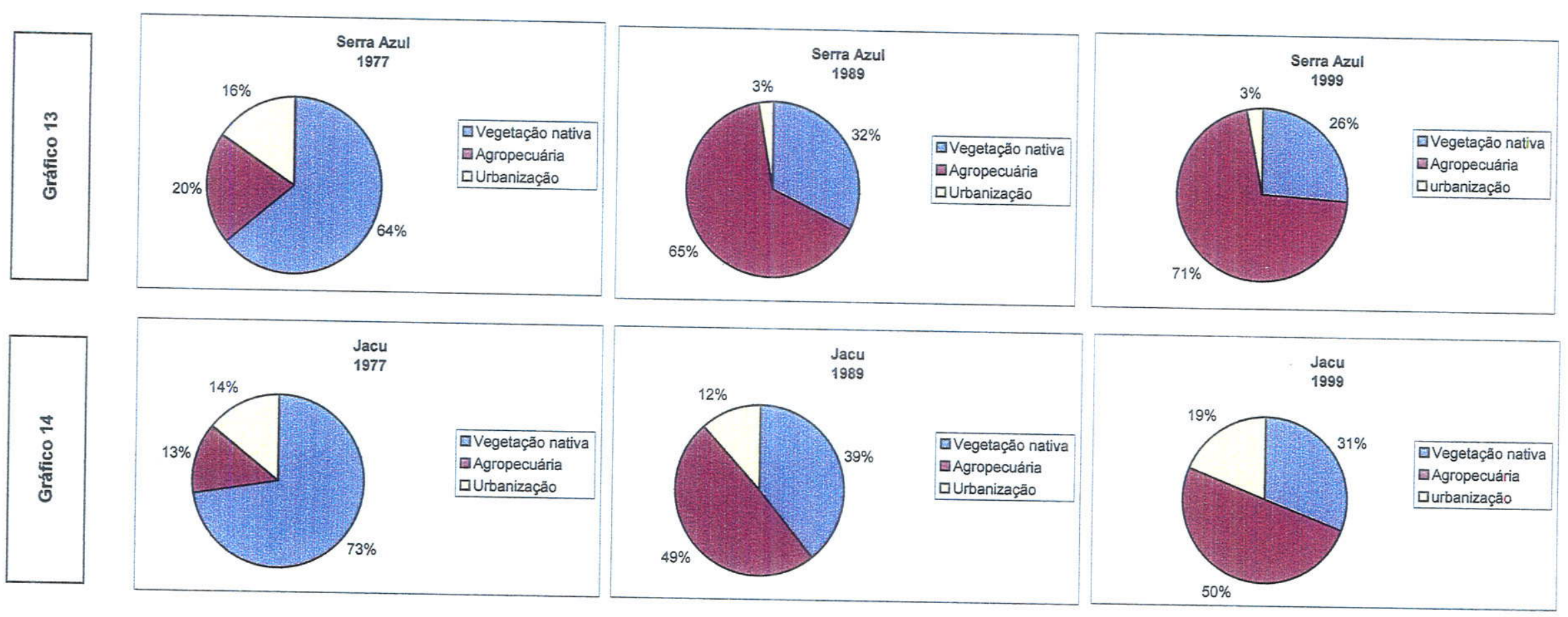

- 品

$=0+$

觉

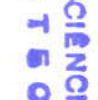

$\rightarrow$

1
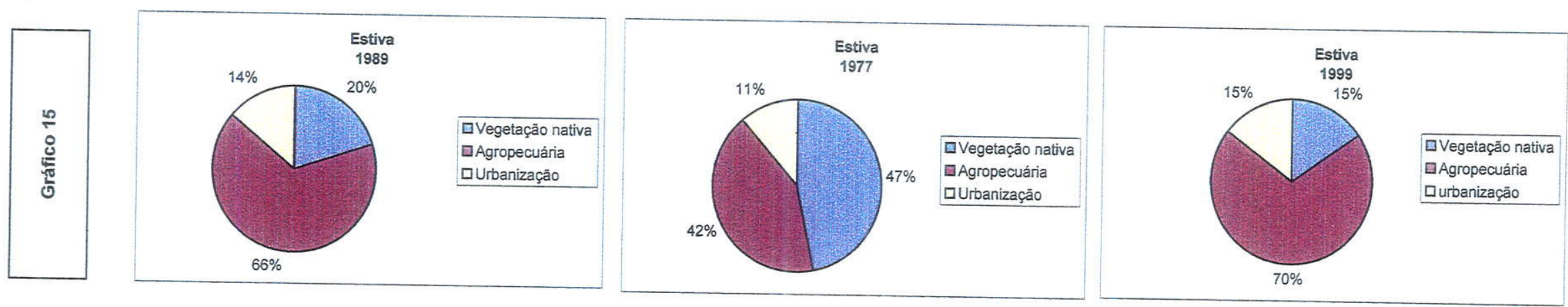

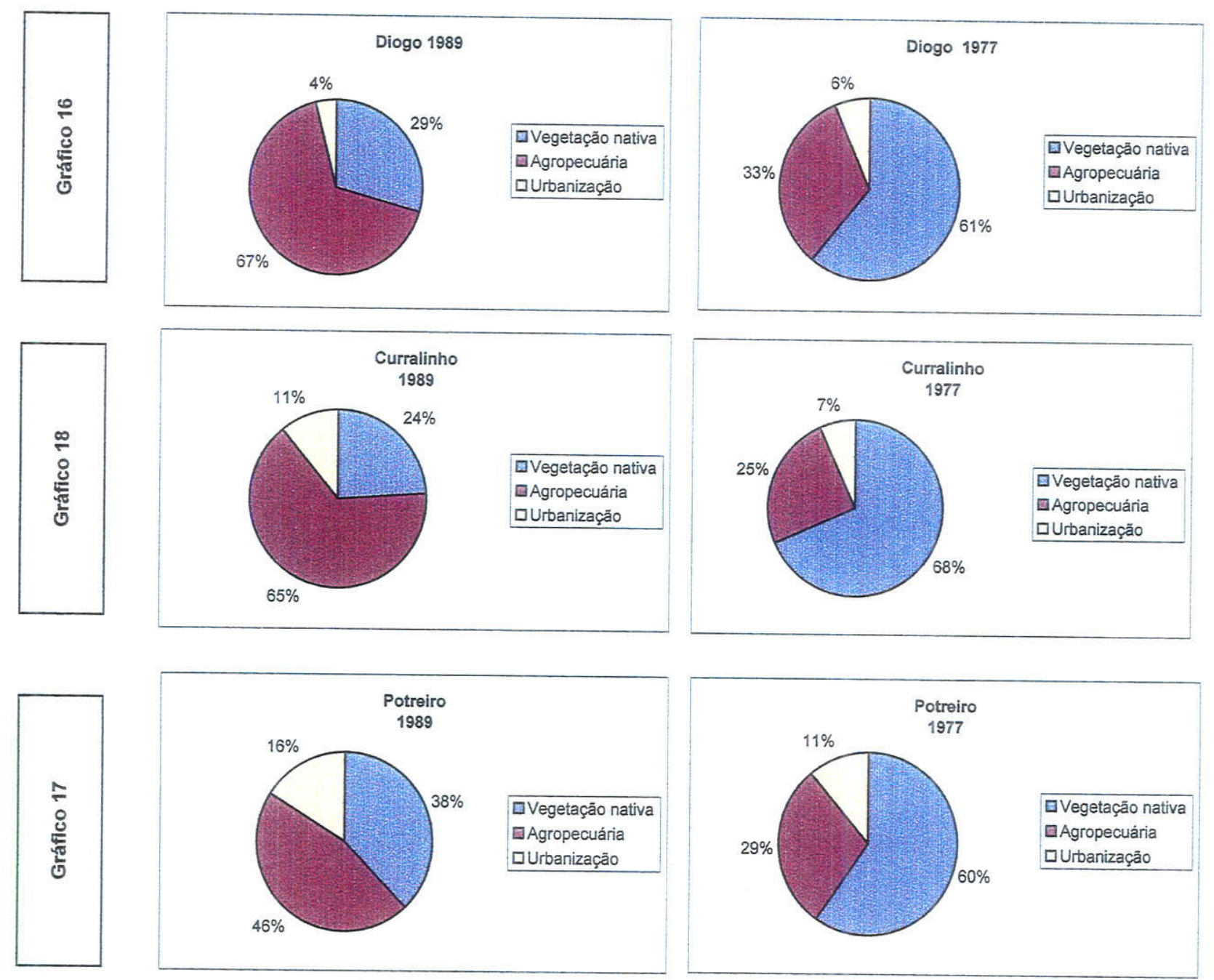
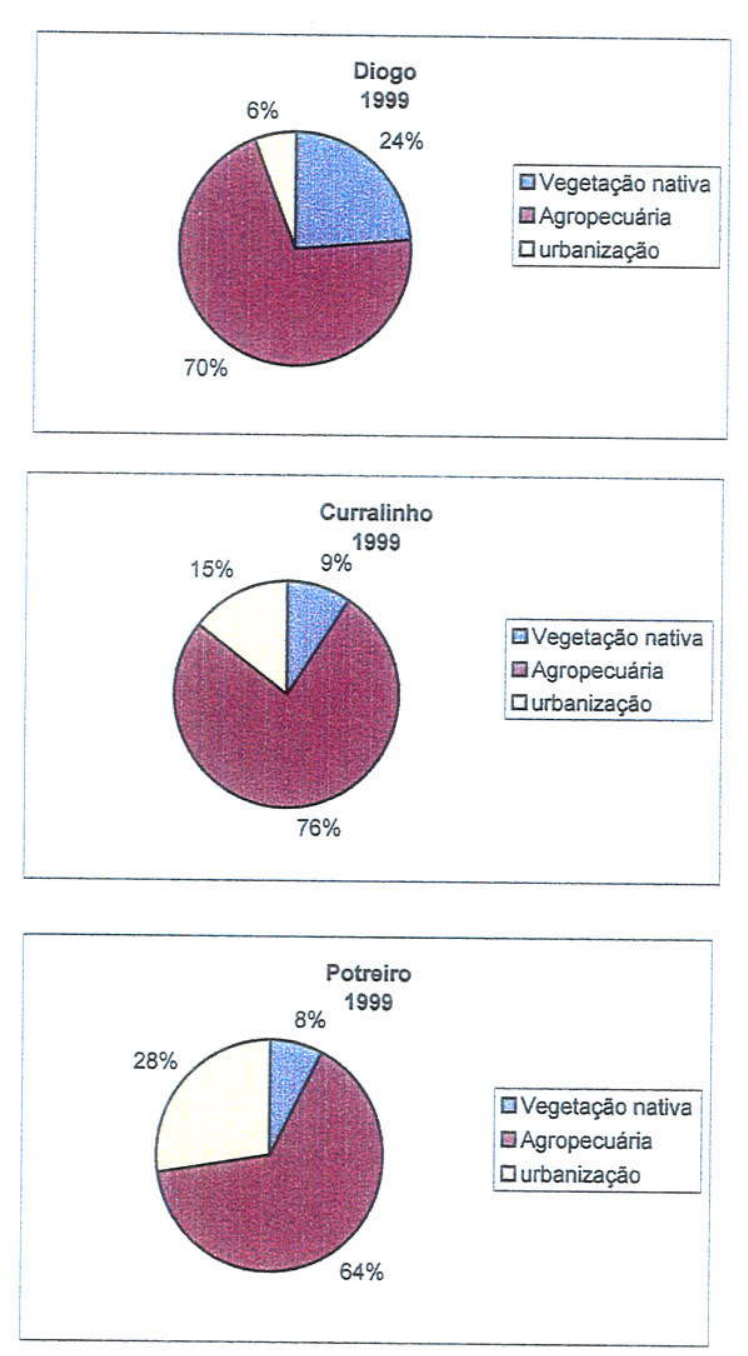
Posteriormente, os dados brutos de 1985-1994, foram agrupados em período seco e úmido, de acordo com a data da coleta, permitindo estimar-se a variação sazonal das variáveis para cada sub-bacia. Năo obstante, procedeu-se à divisão dos dados brutos em dois intervalos de aproximadamente 5 anos cada: janeiro de 1985 a setembro de 1989 e, outubro de 1989 a junho 1994. Isso feito, possibilitou confirmar o comportamento sazonal obtido com os dados brutos da década, e ainda, verificar a variação das medidas não-paramétricas entre os quiinqüiênios.

De acordo com a frequiencia do monitoramento e de maneira a representar os valores assumidos pelas diversas variáveis durante o ano hidrológico, as medianas mensais foram calculadas e dispostas em um gráfico cujo eixo das abscissas, representativo dos meses, partiu de abril e alcançou março.

As não-conformidades foram avaliadas através dos percentis, elementos da estatística indutiva. Os gráficos dos percentis permitiram inferir o percentual de amostras acima ou abaixo dos limites estipulados no enquadramento dos corpos d'água, representando os dados brutos e os períodos seco e úmido.

A determinação dos padrões de variação da concentração com a vazão para a bacia do Serra Azul foi prejudicada devido a não medição da vazão conjuntamente com a coleta das amostras. Mesmo as vazões mensais não têm sido medidas de maneira a representar consistentemente a bacia, constituindo uma falha lamentável. Nos dados disponibilizados pela COPASA, apenas a vazão mensal dos ribeirões Serra Azul e Diogo eram representativas do período de 1985-1994, Anexo 3.

Dessa forma e baseando-se em Michel Meybeck (1989), foi estimado o comportamento das diversas variáveis com as vazóes a partir das respectivas medianas mensais. O Gráfico 19 mostra a vazão mediana para as sub-bacias ao longo do ano.

Os resumos da inferência estatística para todas as variáveis estão dispostos no Anexo 4. 


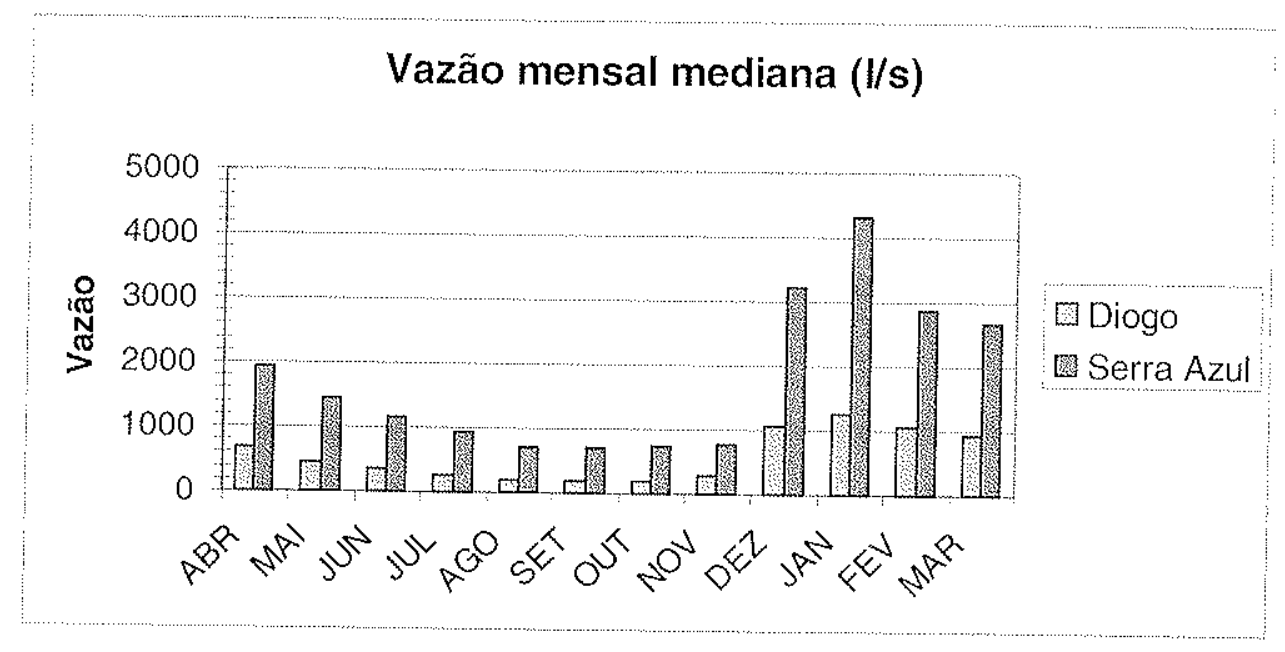

\subsubsection{Coliformes}

\section{Ciclo hidrológico}

Entre 1985-1994, em todas as sub-bacias, com exceção do Estiva, a mediana das análises de Coliformes apresentou uma variação sazonal positiva, ou seja, aumentou no período ámido em relação ao período seco imediatamente anterior.

Dividindo-se os dados em dois períodos: 1985-1989 e 1989-1994, os coliformes mantêm a variação sazonal positiva. Se compararmos as estações nos dois períodos, tem havido crescimento da mediana do primeiro para o segundo quiinqüênio.

De maneira geral, o gráfico das medianas mensais mostra que a variável coliforme fecal tende a acompanhar a mediana da precipitação. A partir de abril há uma tendência de queda, interrompida pelo início das chuvas em setembro ou outubro.

Os meses de chuva teoricamente seriam os piores para essa variável, entretanto, as sub-bacias do Serra Azul, Estiva e Diogo apresentam medianas superiores àquela permitida no enquadramento durante o ano, indicando um quadro endêmico de contaminação fecal. 


\section{Não-conformidade}

Os percentis mostram que a pior situação se encontra na bacia do Serra Azul, com aproximadamente $95 \%$ das amostras acima dos 200 coliformes $/ 100 \mathrm{ml}$. O quadro das sub-bacias se agrava um pouco nas chuvas e melhora um pouco na seca, entretanto, a sub-bacia do Estiva curiosamente apresentou um ligeiro aumento dos coliformes no período da seca, tomando a posição do Serra Azul e indicando uma possível diluição no período úmido. Todos apresentaram mais de $50 \%$ de amostras fora da conformidade.

\section{Relação Vazão x Concentração}

Os gráficos da vazão mostram que os coliformes tendem a aumentar com a vazão, entretanto, o gráfico do Serra Azul caracteriza uma queda do número de coliformes à medida que a vazão continua a crescer. Isso se deve à diluição dos coliformes em uma maior quantidade de água, ou seja, a contribuição de coliforme é menor que a de água. O gráfico do Diogo, mostra uma tendência de crescimento com a vazão, isso pode ser atribuído ao fato da sua bacia apresentar menores área e comprimento, acarretando em uma menor capacidade assimilativa desse corpo d'água em relação ao primeiro.

\subsubsection{Cor}

\section{Ciclo hidrológico}

A inferência dos dados de Cor entre 1985-1994, mostra um incremento nas medianas dos meses úmidos. No ribeirão do Diogo, a mediana úmida aumentou $133 \%$ e no Serra Azul, $80 \%$.

As medianas relativas aos qüinqüênios $1985-1989$ e1989-1994, indicaram um crescimento geral da variável cor, principalmente em Potreiro e Serra Azul.

Os meses de dezembro, janeiro e fevereiro seriam os que apresentam as maiores medianas para a Cor. Os valores mostram o comportamento da variável Cor semelhante ao da precipitação, durante o ciclo hidrológico. As sub-bacias do Serra Azul, Estiva e Jacu apresentaram todas as medianas mensais fora da conformidade. 


\section{Näo-conformidade}

Os gráficos de percentis mostram um comportamento para a variável cor, no mínimo, coeso entre as sub-bacias. De uma maneira geral, pelo menos $75 \%$ das amostras de qualquer sub-bacia em qualquer época estaria acima do permitido. Para as áreas do Serra Azul, Jacu, Estiva e Curralinho, mais de $90 \%$ das amostras no período úmido superaram o limite da Classe 1, de 30 UPT. Esse percentual permanece, mesmo no período seco, para Jacu, Serra Azul e Estiva,

\section{Relação Vazão x Concentração \\ Tanto para o Serra Azul, quanto para o Diogo, as curvas mostram um aumento da cor em relação à vazão. Comportamento geralmente relacionado aos fenômenos de lavagem do solo e remobilização do material de fundo.}

\subsubsection{DBO}

\section{Ciclo hidrológico}

A mediana da DBO apresentou uma variação sazonal positiva entre 19851994. Entre os qüinquiênios de 1985-1989 e 1989-1994, destaca-se os incrementos da mediana na sub-bacia do Estiva, e a queda da DBO na região do Jacu. Entretanto, a frequiência de amostragem da variável DBO parece não ter sido representativa, apresentando medianas mensais aleatórias em relação à distribuição das chuvas.

\section{Não-conformidades}

Os percentis mais uma vez mostraram o aumento da DBO no período úmido, entretanto, em nenhuma delas chega a ser alarmante a porcentagem de amostras acima do limite da Classe 1. Durante o período seco, aproximadamente $10 \%$ das amostras seriam iguais ou maiores que $3 \mathrm{mg} / \mathrm{l} \mathrm{O}_{2}$. Durante o úmido, aproximadamente $20 \%$.

\section{Relação Vazão x Concentração}

A DBO em Serra Azul e Diogo tende a aumentar juntamente com a vazão, entretanto, apresenta um limite máximo que pode ser explicado pela exjstência de 
una estabilização na oferta de matéria orgânica. Para a curva de Serra Azul, ocorre uma ligeira queda nas vazões mais altas, scmellante aos coliformes, indicando uma maior capacidade assimilativa para uma carga limitada.

\subsubsection{Ferro}

\section{Ciclo hidrológico:}

As medianas para a variável Ferro total apresentaram crescimento no semestre úmido em relação ao seco, principalmente nas sub-bacias do Diogo, Serra Azul e Estiva. Apresentou pequena queda, ou seja, variação sazonal negativa, a subbacia do Potreiro. Já o Ferro solúvel (Fe2), se manteve praticamente estável entre as estações.

As medianas mensais mostram que a variável Ferro total tende a acompanhar a distribuição das chuvas durante o ano. Destacam-se as medianas de Potreiro, quase todas acima de $1,5 \mathrm{mg} / \mathrm{Fe}$. O gráfico das medianas mensais do Fe2 mostra uma oscilação marcante, indicando forte influência de processos internos no comportamento dessa variável.

De maneira geral, entre os dois qüinqüênios 85-89 e 89-94, as áreas apresentaram um crescimento da concentração mediana de Ferro total, destacando Serra Azul, Estiva e Potreiro. O Fe2 começou a ser monitorado a partir de 1990, não permitindo essa análise quiinqüienal.

\section{Não-conformidade}

Considerando o limite de potabilidade $0,3 \mathrm{mg} / \mathrm{l} \mathrm{Fe}$ para a variável Ferro total, todas as bacias teriam pelo menos $95 \%$ de não-conformidade, de acordo com os percentis. As medianas mensais se apresentaram por todo o ano acima desse valor para todos as sub-bacias.

O Fe2, dado a sua instabilidade, alterna com períodos abaixo do limite de 0,3 mg/l Fe. Para a sub-bacia do Serra Azul, aproximadamente $48 \%$ das amostras no período úmido estariam acima daquele valor. As restantes apresentaram menos de $20 \%$ de não-conformidade. 
Relação Vazão x Concentração

Ambos os gráficos da variável Ferro total com a vazão, mostram seu crescimento exponencial em Serra Azul e Diogo. Dada a presença no solo dos compostos de ferro, esse comportamento dos pontos corrobora com os efeitos de lavagem superficial e arraste de fundo provocados pela chuva. Da mesma forma, o Ferro solúvel em Serra Azul cresce, ainda que mais lentamente, com a vazão. Em Diogo as vazões máximas passam a apresentar as mesmas concentrações das vazões mínimas, indicando queda na disponibilidade do Fe2 com o aumento da vazão.

\subsubsection{Manganês total.}

\section{Ciclo hidrológico}

De uma maneira geral, a variável Manganês total apresenta uma variação sazonal positiva, principalmente na bacia do Serra Azul. Entretanto, na bacia do Estiva a concentração mediana dessá variável não se modifica, e em Potreiro ela varia muito pouco, aproximadamente $7 \%$. Entre os quinquênios, a mediana tem mostrado queda, principalmente em Diogo.

Mensalmente, a mediana do manganês tem mostrado comportamento semelhante à pluviometria, entretanto, os ribeirões Estiva, Jacu e Potreiro, apresentam picos de concentração no semestre seco, garantindo a eles concentrações altas durante todo o ano hidrológico.

\section{Não-conformidade}

A análise das curvas de percentis ilustram como a área do Estiva tem apresentado as maiores concentrações de manganês, seguido por Jacu e Potreiro. Considerando o valor de $0,1 \mathrm{mg} / \mathrm{l} \mathrm{Mn}$ para a Classe 1 , essas sub-bacias apresentam mais de $80 \%$ de amostras em situação de não-conformidade. No caso do Estiva, no período seco esse percentual se agrava passando de $90 \%$ a não-conformidade. As demais áreas apresentam $30 \%$ ou menos de amostras acima do limite da classe. 


\section{Relação Vazão x Concentração}

Assim como o ferro total, o manganês lolal aumenta exponencialmente com a vazão, dada a sua presença significativa no solo.

\subsubsection{Nitrato}

\section{Ciclo hidrológico}

Na bacia do Serra Azul o nitrato apresenta uma variação sazonal positiva. As medianas mensais mostram uma queda a partir de abril para alcançar um pico próximo do início das chuvas. Esse fato pode indicar uma influência da carga inicial de lavagem do solo.

Entre os quinquênios de 85-89 e 89-94, as medianas mostram um crescimento percentual, principalmente em Potreiro, Estiva e Diogo.

\section{Não-conformidade}

O limite estipulado para o nitrato na Classe 1 é de $10 \mathrm{mg} / \mathrm{l} \mathrm{N}$, dessa forma, não ocorre caso de não-conformidade em nenhuma das sub-bacias para essa variável. Os percentis mostram uma concentração mediana no período úmido próxima de 0,1 $\mathrm{mg} / \mathrm{l}$ e no período seco, em torno de $0,06 \mathrm{mg} / \mathrm{l}$. Os piores resultados estariam na área do Serra Azul, Estiva e Potreiro.

\section{Relação Vazão $x$ Concentração}

Os gráficos da vazão e a variável nitrato mostram um desenvolvimento logarítmico, ou seja, a concentração de nitrato tende a atingir um máximo. Dado o fato que o nitrato corresponde ao estado final de transformação da série nitrogenada, ele realmente tende aumentar indiscriminadamente com a vazão, entretanto se apresenta limitado à quantidade carreada de nitrogênio na bacia.

\subsubsection{Nitrito}

Não apresentou variação dentro do período de monitoramento. Quase a totalidade dos resultados foram iguais a $0,002 \mathrm{mg} / \mathrm{I} \mathrm{N}$. Isso se deveu talvez ao fato do 
nitrito se transformar em nitrato com certa velocidade, não sendo significativa sua análise em amostragens mensais.

\subsubsection{Oxigênio Dissolvido}

\section{Ciclo hidrológico}

Durante o ciclo hidrológico, a variável OD apresentou uma variação sazonal negativa em todas as sub-bacias. Há uma queda generalizada na concentração de oxigênio também entre os qüinqüiênios 85-89 e 89-94.

O grafico das medianas mensais ilustra como o oxigênio dissolvido atinge seus valores mais altos nos meses de julho e agosto, os mais secos do ano. De maneira geral, o Potreiro é o ribeirão com menores as medianas de oxigênio, atingindo um máximo em julho de 7,5 mg/l.

\section{Não-conformidade}

Os percentuais acumulados mostram um comportamento semelhante para os mananciais en relação a variável OD. Nas sub-bacias do Potreiro e Jacu, foram obtidas as concentrações mais baixas que, entretanto, não ultrapassaram $12 \%$ dos resultados abaixo de $6 \mathrm{mg} / \mathrm{I} \mathrm{O}_{2}$.

\section{Relação Vazão x Concentração}

A variável Oxigênio dissolvido apresenta um comportamento de queda à medida que a vazão aumenta. Se a oferta de oxigênio na água for limitada e dependente da solubilidade e produção primária em um dado momento, a entrada de substâncias consumidoras desse oxigênio juntamente com o escoamento superficial provocado pela chuva, implicaria em uma diminuição do mesmo. Dessa forma, a mistura de águas com diferentes concentrações de oxigênio, provocaria a diminuição da oferta desse gás naquela com maior quantidade inicial, ou seja, diluição. 


\subsubsection{Fósforo total}

\section{Ciclo hidrológico}

O teor de fósforo aumenta durante as chuvas, principalmente em Serra Azul, cuja mediana sofre um aumento de $80 \% \mathrm{~cm}$ relação ao semestre seco. Em Potreiro ocorre uma ligeira queda percentual sazonal do fósforo. Entre os qüinquäentios 85-89 e 89-94, houve crescimento das medianas em todas as sub-bacias, destacando-se Curralinho, com mais de $200 \%$ de diferença.

As medianas mensais mostram um comportamento aleatório das inferências. Os maiores valores se concentrariam em dezembro e fevereiro, a cargo do Serra Azul, Estiva, Diogo e Curralinho. Em agosto ocorre um pico em Potreiro e Serra Azul, podendo ter alguma relação com as primeiras chuvas.

\section{Não-conformidade}

A concentração de fósforo para a classe 1 é de $0,025 \mathrm{mg} / \mathrm{l}$ P. Os percentis mostram que para Serra Azul e Estiva, mais de $50 \%$ das amostras estariam acima desse limite no período úmido.

No semestre seco, nota-se que em Potreiro mais amostras superaram o limite de $0,025 \mathrm{mg} / \mathrm{I} \mathrm{P}$, em torno de $45 \%$ delas, em relação ao período úmido. Esse comportamento difere das outras sub-bacias, quando tiveram uma reduçăo de nãoconformidades.

\section{Relação Vazão x Concentração}

O fósforo apresenta um crescimento até determinada vazão, a partir da qual, passa a prevalecer a diluição do mesmo. Isso fica mais evidenciado na distribuição dos fósforo para o Serra Azul, onde o valor máximo daquela variável coincide com um valor intermediário de vazão. 


\section{Ciclo hidrológico}

O pH apresentou uma variação sazonal negativa durante o ano hidrológico. As medianas mensais mostram um comportamento de tendência mais neutra nos meses secos e mais ácida nos úmidos.

As sub-bacias do Estiva, Diogo, Curralinho e Potreiro, possuem medianas inferiores ou iguais a 7 durante todos os meses.

\section{Não-conformidade}

$O$ intervalo de $\mathrm{pH}$ preconizado pelo enquadramento na classe 1 seria de 6,0 a 9,0 . Nos gráficos de percentis, a não-conformidade seria pequena, com menos de $5 \%$ das amostras abaixo de 6,0. Em nenhuma amostra, o pH superou 9,0.

Em Serra Azul, aproximadamente $46 \%$ das amostras seriam menores ou iguais a 7,0 no semestre úmido. Em Jacu, 58\%; em Estiva, 72\%; em Diogo, 78; em Curralinho e em Potreiro, $85 \%$ delas.

Na seca, teríamos em Serra Azul 30\%; Jacu 35\%; Diogo 64\%; Potreiro 77\%; Estiva 78\%; e Curralinho, com $88 \%$ das amostras iguais ou abaixo de 7 .

\section{Relação Vazão x Concentração}

Diogo e Serra Azul apresentam queda no pH com o aumento da vazão. De maneira semelhante ao OD, o pH sofre influência das vazões mais altas e possuidoras de maior quantidade de dióxido de carbono e matéria orgânica.

\subsubsection{Turbidez,}

\section{Ciclo hidrológico}

Essa variável também apresentou variação sazonal positiva, indicando águas mais turvas no período das chuvas em todas as sub-bacias. Em Serra Azul, a mediana da turbidez aumentou em torno de $144 \%$ no período úmido, entretanto, na variação entre os qüinqüiênios, essa variável tem mostrado tendência de queda, com exceção da sub-bacia do Potreiro, cujo aumento se aproximou de $50 \%$. 
As medianas mensais da variável SS se mostraram em consonância com aquuelas da precipitação. As medianas mais altas se encontraram principalmente em dezembro e janeiro, principalmente em Serra Azul e Estiva.

\section{Não-conformidade}

Os percentis mostram que no período úmido as piores situações seriam: Serra Azul, apresentando $32 \%$ das amostras acima da Classe 1, e Jacu, com $28 \%$ delas acima de 40 NTU.

No período seco as curvas mostram uma queda geral na variável Turbidez, com menos de 5\% de transgressões ao limite de classe. Destaca-se Potreiro e Jacu, com medianas iguais a 11 e 10 , respectivamente.

\section{Relação Vazão x Concentração}

A turbidez apresentou crescimento exponencial com a vazão em ambas as sub-bacias: Serra Azul e Diogo. Esse comportamento se explica pela relação entre essa variável e os sólidos carreados.

\subsubsection{Sólidos em Suspensão}

\section{Ciclo hidrológico}

A mediana da variável Sólidos em Suspensão apresentou variação sazonal positiva em todas as sub-bacias, principalmente em Serra Azul: 200\%. As medianas mensais, apesar das oscilações, são capazes de mostrar o aumento dos sólidos nos meses úmidos.

O monitoramento dessa variável teve início no ano de 1990.

\section{Relação Vazão x Concentração}

O gráfico referente à bacia do Serra Azul mostra que a concentração dos sólidos suspensos possui uma tendência de queda ao persistir o aumento da vazão. Da mesma forma, entretanto, mais suavemente, a sub-bacia do Diogo indica uma queda na concentração de sólidos em vazões mais altas. Tal fato pode ser entendido como uma diminuição do material arrastado pelo escoamento superficial. 


\subsection{Variação da qualidade da água e do uso do solo}

A partir dos Gráficos 13 a 18, e do Anexo 4, resumiu-se na Tabela 7, as análises pertinentes à qualidade da água e o uso do solo nas sub-bacias do ribeirão Serra Azul.

Assim, a variável Coliforme fecal obteve variações sazonais positivas principalmente para Potreiro e Jacu, as bacias com maiores percentuais de Urbanização. Em Estiva, a concentração mediana de Coliformes diminuiu no período úmido (variação sazonal negativa), e da mesma forma entre os qüinqüênios, indicando nesse caso uma prevalência de cargas pontuais como forma de contaminação. Nas demais sub-bacias há maior impacto de cargas difusas.

A variável DBO apresentou variação sazonal positiva para todas as subbacias, principalmente em Potreiro e Estiva. Entretanto, o comportamento entre os qüinqüêenios se mostra confuso, prevalecendo crescimento da mediana no período seco e queda no período úmido. Mesmo em sub-macias como a do Serra Azul ou Potreiro, onde houve um aumento no grupo Agropecuária e Urbanização, ocorre queda da DBO no período de maior contribuição difusa.

A variável Oxigênio Dissolvido teve variação sazonal negativa, bem como, decresceu entre os qüinqüênios. Essa tendência de queda corrobora a degradação sofrida pela bacia como um todo.

O pH apresentou crescimento com o tempo em todas as sub-bacias. Tanto no qüinqüênio seco como no úmido, os percentuais não mostraram relação mais direta com a variação do uso do solo nas sub bacias.

As variáveis Cor, Sólidos em Suspensão e Turbidez foram grandemente influenciadas pelo período de chuva, havendo unanimidade na variação sazonal positiva para todas as sub-bacias, principalmente em Serra Azul e Diogo. Quanto à variação entre os qüinquiênios, a Cor apresentou aumento enquanto a Turbidez diminuiu com o tempo. Como exceção tem-se a sub-bacia do Potreiro, única a sofrer aumento da Turbidez com o tempo e possuidora do maior aumento de Cor para o mesmo período. Essa sub-bacia teve o grupo Vegetação nativa restrito a apenas $8 \%$ de seu território e seus loteamentos ainda se apresentavam em consolidação, constituindo aproximadamente $28 \%$ da sub-bacia. 


\begin{tabular}{|c|c|c|c|}
\hline \multicolumn{2}{|c|}{ Variáveis } & $\begin{array}{c}\text { Tendência da } \\
\text { Mediana }\end{array}$ & $\begin{array}{c}\text { Eventos climáticos/uso do solo } \\
\text { relacionados }\end{array}$ \\
\hline \multirow{6}{*}{$\begin{array}{c}\text { Físico-químicas } \\
\text { Biológicas }\end{array}$} & Cor & Aumento & $\begin{array}{l}\text { Chuvas, eliminação da vegetação } \\
\text { nativa e aumento da Agropecuária e } \\
\text { Urbanização. }\end{array}$ \\
\hline & $\mathrm{DBO}$ & Aumento & Chuvas. \\
\hline & $\begin{array}{l}\text { Oxigênio } \\
\text { Dissolvido }\end{array}$ & Queda & $\begin{array}{l}\text { Chuvas, degradação da Vegetação } \\
\text { nativa, aumento da Agropecuária e } \\
\text { Urbanização }\end{array}$ \\
\hline & $\mathrm{pH}$ & Instável & $\begin{array}{l}\text { Durante as chuvas o pH diminuiu } \\
\text { em algumas bacias e se manteve } \\
\text { estável em outras. Seu valor cresceu } \\
\text { com o tempo, indiferentemente das } \\
\text { modificaçoes do uso do solo. }\end{array}$ \\
\hline & Coliformes & Aumento & $\begin{array}{l}\text { Chuvas, Agropecuária e } \\
\text { Urbanização incipiente (Potreiro e } \\
\text { lacu) }\end{array}$ \\
\hline & & Queda & $\begin{array}{l}\text { Chuvas e Urbanização consolidada } \\
\text { (Estiva) }\end{array}$ \\
\hline \multirow{3}{*}{ Nutrientes } & Nitrito & Estável & Indiferente ao clima e ao uso do solo \\
\hline & Nitrato & Aumento & Chuvas e Agropecuária. \\
\hline & P total & Aumento & $\begin{array}{l}\text { Chuvas, Agropecuária e eliminação } \\
\text { Vegetação nativa. }\end{array}$ \\
\hline \multirow{5}{*}{ Sólidos } & Ferro Solúvel & Instável & $\begin{array}{l}\text { Aumentou e, principalmente } \\
\text { diminuiu com as chuvas, mesmo nas } \\
\text { areas de avanço da Agropecuária e } \\
\text { Urbanização, nâo acompanhando o } \\
\text { Ferro total e o pH. }\end{array}$ \\
\hline & Ferro total & Aumento & $\begin{array}{l}\text { Chuvas, expansão da Agropecuária } \\
\text { e Urbanização, histórico de } \\
\text { mineração. }\end{array}$ \\
\hline & $\begin{array}{l}\text { Manganês } \\
\text { total }\end{array}$ & Aumento & Chuvas. \\
\hline & $\begin{array}{l}\text { Sólidos em } \\
\text { Suspensão }\end{array}$ & Aumento & Chuvas. \\
\hline & Turbidez & Aumento & $\begin{array}{l}\text { Chuvas, Agropecuária e } \\
\text { Urbanização incipiente (Potreiro). }\end{array}$ \\
\hline
\end{tabular}

Tabela 7 - Relação entre a evolução das variáveis de qualidade da água e eventos climáticos e do uso do solo na Bacia do ribeirão Serra Azul.

Assim como o Manganês total, também influenciado pelas chuvas, o Ferro total teve variação sazonal positiva em todas as sub-bacias, excetuando-se Potreiro. Em todas as sub-bacias o Ferro total teve sua mediana aumentada entre 1985-1989 e 1989-1994, principalmente em Serra Azul e Estiva, ambas com histórico de mineração, e em Potreiro, a área de maior extinção da vegetação nativa. Opondomse ao comportamento do Ferro total, o Manganês total sofreu diminuição da mediana com o tempo principalmente em Estiva e Diogo. 
O Ferro solúvel teve variação sazonal positiva apenas em Estiva, em torno de 170\%. Nas demais bacias, a concentração mediana de Ferro solúvel diminuiu com as chuvas, diferentemente do Ferro total.

O nutriente Nitrito não apresentou variação significativa dentro do período de monitoramento. O Nitrato teve variação sazonal positiva para todas as bacias. Entre os qüinqüênios, houve crescimento geral da concentração de Nitrato, principalmente en Estiva, cujo aumento foi de $670 \%$ entre o período seco, e em Potreiro, que aumentou $225 \%$ entre o período úmido.

A variável fósforo total contou com variação sazonal positiva de $80 \% \mathrm{em}$ Serra Azul, a sub-bacia com maior área agrícola. Em termos de variação temporal, o qüinquiênio seco aumentou principalmente em Curralinho, 583\%, e o qüinqüiennio úmido em Potreiro, com $300 \%$. 


\section{Conclusões}

As variações da qualidade da água e do uso do solo ocorridas entre os pares de sub-bacias definidos pela Densidade de drenagem e índice de rugosidade, mostraram uma interação heterogênea entre esses temas. Dessa forma, variações semelhantes de uso do solo não implicaram nas mesmas variações para a qualidade dá água.

Em termos gerais, o cenário é de expansão da ocupação por Agropecuária e Urbanização, em detrimento da Vegetação nativa, principalmente em Potreiro. Nas demais sub-bacias, tem havido expansão da ocupação antrópica, mas com menor intensidade. Essa diminuição da Taxa de uso do solo foi acompanhada pela variação das medianas da Turbidez e do Manganês total, cuja tendência foi de queda com o tempo.

Para Coliformes, Cor, Ferro total, Nitrato, OD e Fósforo total, a tendência foi de piora da qualidade, indicando que a expansão do uso do solo para Agropecuária e Urbanização, ainda que menor no último período, continua a aumentar o impacto dessas variáveis. Destaca-se o aumento das medianas de Fósforo e Nitrato durante o período seco, indicando possível assimilação desses compostos pela água subterrânea.

Não foi constatada uma variação comum entre as sub-bacias capaz de definir o comportamento das variáveis DBO, pH, Nitrito e Ferro solúvel frente ao clima e aos grupos de uso do solo. Para essas variáveis, parecem pesar mais en seu desenvolvimento as condições endógenas ao corpo hídrico, resultado da interação do material suspenso, dissolvido e de fundo, insensíveis no monitoramento.

Em termos quantitativos, a interação morfologia, uso do solo e qualidade da água, mostroumse mais direta, principalmente para o par Estiva e Diogo. Através das vazões mensais de Serra Azul e Diogo, foram estimadas as descargas líquidas das demais sub-bacias, proporcionalmente à área de cada uma. A partir disso, foi avaliada a produção $\mathrm{em} \mathrm{kg} / \mathrm{ha} / \mathrm{ano}$, para o ferro, manganês, fósforo, nitrato e nitrito, e ainda, DBO e sólidos em suspensão (Tabela 8). A sub-bacia do Potreiro, única com diminuição na Taxa de uso do solo para Vegetação nativa, superou as demais na 
produção de Ferro total, Nitrato e DBO. A produção de sólidos foi liderada por Serra Azul e Estiva, as sub-bacias com maior histónico de mineração.

\begin{tabular}{|c|c|c|c|c|c|c|c|c|}
\hline Produção (kg/ha/ano) & $\begin{array}{l}\text { Fe total }(\mathrm{kg} \\
\mathrm{Fe})\end{array}$ & $\mathrm{Fe} 2(\mathrm{~kg} \mathrm{Fe})$ & $\begin{array}{c}\text { Mn total }(\mathrm{kg} \\
\mathrm{Mn})\end{array}$ & $\begin{array}{c}\text { Nitrato }(\mathrm{kg} \\
\mathrm{N})\end{array}$ & {$\left[\begin{array}{c}\text { Nitrito }(\mathrm{kg} \\
\mathrm{N})\end{array}\right.$} & $\begin{array}{c}\mathrm{P} \text { total }(\mathrm{kg} \\
\mathrm{P})\end{array}$ & $\begin{array}{c}\mathrm{DBO} \\
\mathrm{O} 2)^{(\mathrm{kg}}\end{array}$ & $(\mathrm{kg})$ \\
\hline Cunalinho & 9,503 & 0,684 & 0,461 & 0,475 & 0,010 & 0,148 & 3,740 & 35,438 \\
\hline Potreiro & 10,041 & 0,322 & 0,801 & 0,536 & 0,012 & 0,127 & 6,229 & 84,714 \\
\hline Diogo & 8,108 & 1,236 & 0,616 & 0,468 & 0,012 & 0,149 & 5,917 & 59,165 \\
\hline Estiva & 8,634 & 1,288 & 1.060 & 0,396 & 0,011 & 0,137 & 5,947 & 93,168 \\
\hline Jacu & 7.679 & 0,957 & 0,946 & 0,451 & 0,010 & 0,121 & 5,129 & 67,582 \\
\hline Serra AZul & $\begin{array}{r}9,128 \\
8 . P r\end{array}$ & 1,688 & 0,388 & 0,470 & 0,009 & 0,181 & 6,034 & 187,957 \\
\hline
\end{tabular}

Comparando-se a taxa de produção de Fósforo nos Estados Unidos, Quadro 11, com a taxa de produção em Serra Azul, conclui-se que essa última apresenta-se bem menor. Entretanto, se for considerada apenas a área relativa a Agropecuária em Serra Azul, a taxa de produção passaria a ser $0,3 \mathrm{~kg} / \mathrm{ha} / \mathrm{ano}$, aproximando-se daquela encontrada por Chapra (1997).

\begin{tabular}{|c|c|c|c|c|}
\hline Nutrientes & Florestas & Agricultura & Areas urbanas & Atmosfera \\
\hline $\mathrm{P}$ & 0,4 & 0,5 & 1 & 1 \\
\hline $\mathrm{N}$ & 3 & 5 & 5 & 24 \\
\hline
\end{tabular}

obtida nos Estados Unidos para a produçăo $\mathrm{em} \mathrm{kg} / \mathrm{ha} / \mathrm{ano}$, de fósforo $\mathrm{e}$ nitrogênio. Fonte: Chapra (1997), p. 531.

A análise do comportamento das concentrações com as vazões, mesmo que limitada aos valores medianos mensais, mostrou que a maioria dos compostos que alcança as drenagens é de origem difusa. Contraditoriamente, o período úmido, responsável pela renovação dos recursos hídricos, seria aquele em que, sob a ótica do Enquadramento e da Potabilidade, ocorreria uma piora geral da qualidade da água na bacia. A Tabela 9 ilustrá a situação das sub-bacias quanto ao percentual de transgressão da Classe 1 durante o período de chuvas. 


\begin{tabular}{|c|c|c|c|c|c|c|}
\hline Variáveis & Curralinho & Diogo & Estiva & Jacu & Potreiro & Serra Azul \\
\hline 1. Fe total & 99 & 99 & 99 & 99 & 99 & 99 \\
\hline 2. Cor & 87 & 96 & 93 & 98 & 90 & 96 \\
\hline 3. Coliformes & 68 & 88 & 83 & 77 & 55 & 96 \\
\hline 4. Mn total & 44 & 45 & 92 & 85 & 87 & 47 \\
\hline 5. P total & 50 & 47 & 56 & 45 & 29 & 60 \\
\hline 6. Fe2 & 5 & 15 & 32 & 32 & 19 & 48 \\
\hline 7. Turbidez & 8 & 19 & 21 & 28 & 20 & 32 \\
\hline 8. DBO & 4 & 6 & 17 & 15 & 6 & 13 \\
\hline 9. OD & 6 & 0 & 2 & 10 & 10 & 2 \\
\hline 10. pH & 2 & 0 & 0 & 2 & 2 & 2 \\
\hline 11. Nitrito & 0 & 0 & 0 & 0 & 0 & 0 \\
\hline 12. Nitrato & 0 & 0 & 0 & 0 & 0 & 0 \\
\hline
\end{tabular}

Tabela 9 - Inferência estatística: percentual de amostras em não-conformidade com a Classe I durante o semestre úmido.

Considerando-se que as transgressões ocorridas para Ferro Total, Cor, Manganês Total e Fósforo Total, tiveram relação com os sólidos em suspensão, torna-se necessário adotar medidas de controle dos sedimentos que aportam as drenagens. Dessa forma, tem-se a Lei Estadual N. 12.503 , de 30 de maio de 1997 , que criou o Programa Estadual de Conservação da Água, e cujo artigo segundo obriga as empresas concessionárias de serviços de abastecimento de água, como a COPASA, a investir na proteção da bacia o mínimo de $0,5 \%$ do valor total da receita operacional ali apurada, como fonte de recursos para investimentos em ações que possam dirimir esse quadro:

- apoio técnico aos agricultores,

- a reconstituição gradativa da vegetação ciliar em lugar das lavouras ribeirinhas,

- Levantamento e recuperação dos passivos das minerações.

No caso dos Coliformes, o saneamento urbano e rural em toda a bacia seria a medida mais urgente, uma vez que as maiores produtoras de hortifrutiferos: Serra AzuI, Diogo e Estiva, apresentaram mais de $80 \%$ de não-conformidade para essa variável. É comum na área rural encontrar-se residências nas proximidades dos córegos. Além de não respeitarem a faixa de proteção, $30 \mathrm{~m}$ para cada lado, despejam os esgotos diretamente na água. Com a efetivação das atividades do Comitê de Bacia do Rio Paraopeba e a criação da Agência de Bacia, estima-se que somente da captação do SSA/COPASA, arrecade-se em torno de 500 mil reais por ano. Esse valor baseia-se em uma captação aproximada de $1750 \mathrm{l} / \mathrm{s}$ e un custo 
aproximado daquele definido para a bacia federal do Rio Paraíba do Sul: $\mathrm{R} \$ 0,008$ por metro cúbico.

Finalmente, os municípios de Igarapé e Mateus Leme devem implantar seus Planos Diretores o mais rápido possível. Além de criar dispositivos legais de planejamento e controle do solo que envolveriam quase a totalidade da bacia do Serra Azul, eles estariam cumprindo a Lei Federal N. 10.257 de 10 de julho de 2001, chamada Estatuto das Cidades, cujo artigo 41 obriga a todos os municípios integrantes de regiões metropolitanas a adotar esse instrumento de gestão. 


\section{Bibliografia}

ABNT, 1996. Sistemas de Gestão Ambiental - Especificações e diretrizes. NBR ISSO 14001.

_. Sistemas de Gestão Ambiental - Diretrizes gerais sobre princípios, sistemas e técnicas de apoio. NBR ISSO 14004.

Berger, A. R.; 1996. Introduction to geoindicator checklist. In: A. R. Berger e W. J. Jams (eds.). Geoindicators. Assessing rapid environmental changes in earth systems. AA Balkema, Roterdam. p. 383-394.

Bertoni, J.; Neto, F. L.; 1990. Conservação do solo, Ed. Icone, $3^{\text {a }}$ ed., São Paulo.

Bezerra, Maria C. L.; 1996. Planejamento e gestão ambiental, uma abordagem do ponto de vista dos instrumentos economicos. Tese de doutorado apresentada na FAU/USP.

Câmara, G. et al.; 1996. Anatomia de SIG, Instituto de Computação, Unicamp, Campinas(SP).

Camil, K.; 2000. Processos erosivos e planejamento urbano: carta de risco de erosão das áreas urbanas e periurbanas de Franca (SP). Dissertação Geografia/FFLCH/USP, 90p.

Centro de assentamentos humanos da Universidade de British Columbia, Vancouver/Canadá, Prefeitura do Município de Santo André, Gerenciamento Participativo das Áreas Mananciais em Santo André(SP), 1998.

CETESB, 1987; Guia de coleta e preservação de amostras de água. Coord. Edmundo G. Agudo. 1 ed., 150p. 1990; Compilação de Padrões Ambientais. 1a. ed. São Paulo.

COPASA, 1983. Proposta de Manejo do Reservatório Serra Azul. COPASA e Lúcio Gomide Consultoria. 
1998. Preservação do Reservatório Serra Azul. COPASA e Centro

Tecnológico de Minas Gerais (CETEC-MG).

Chapra, S. C.,1997, Surface Water-Quality Modeling, McGraw Hill, Bolder EUA. 844p.

EPA - Seminar Publication - National Conference on Environmental Problemsolving with Geographic Information Systems. Cincinnati, Ohio - 1994.

Eslinger, Eric, et al.; Introduction to Environmental Hidrogeology, SEPM

(Society for Sedimentary Geology).

Hirata, R. C. A.; 1994; Fundamentos e Estratégias de Proteção e Controle da Qualidade das Águas Subterrâneas. Estudo de caso no estado de SP. Tese de Doutorado IG/USP.

IGA/MG (1981). Região Sudeste do Brasil. Folhas Azurita, Mateus Leme, Igarapé, Itatiaiuçu, Itaúna e Juatuba, Escala 1:25.000.

(1983). Mapeamento Geológico da Região Metropolitana de Belo

Horizonte. Folhas Esmeraldas e Igarapé, Escala 1:50.000.

(1985). Mapeamento do Município de Mateus Leme (MG). Folha única,

Escala 1:50.000.

Lakatos, E. M.; Marconi, M. A.; 1990, Fundamentos de Metodologia Científica. $2^{\text {a }}$ ed., Ed. Atlas S.A., São Paulo.

Lal, R.; 1989. Soil Erosion Research Methods, Soil and Water Conservation Society, Seatle - EUA.

Mardment, D. R.; Handbook of Hidrology, McGraw Hill, 1992.

Martins, M. Lourdes Neto; 1996; Tese: Dinâmica do Ferro e Manganês no hipolímio do Reservatório Serra AzuI. UFMG, 123pp. 
Odum, E. P., 1989. Ecology and our endangered life support systems. Ed. Sunderland Sinauer.

ONU/Comissão Mundial para o Meio Ambiente; 1988. Nosso futuro comum. FGV/RJ.

ONU/BID; s/data. Nossa própria agenda. Cap. 3.1.2 Deterioração ambiental dos assentamentos humanos. BID.

Ortolano, L.; 1984. Environmental Planning and Making Decision. Ed. John Wiley and Sons, Stanford. 272p.

Pacheco, Regina S.; 1992. Atores e conflitos em questões ambientais urbanas. $\mathrm{FGV/SP}$.

Rebouças, Aldo C., Braga, B., Tundisi, José G., 1999. Águas doces no Brasil Capital ecológico, uso e conservação. JEA/USP .... Editora Escrituras.

Reis, Ruibram J.; 1996; Tese: Estudo comparativo de modelos climatológicos de estimativa de evaporação do Lago Serra Azul. UFMG, 119p.

Sawyer, Clair N., 1994; Chemistry for Environmetal Engineering. McGraw-Hill, $4 \mathrm{ed}, 658 \mathrm{p}$.

Simões, S. J. C.; 1996. Variabilidade, Fragilidade e Dinâmica da Paisagem em Área Urbano-Rural; Tese de Doutorado FFLCH/GEOG/USP.

Tucci, Carlos E. M.; 1993. Hidrologia e Aplicação, Ed. UFRGS, Porto Alegre.

Troppmair, Helmut; 1988. Metodologia simples para pesquisar o meio ambiente. Rio Claro, Graff Set, 232 p. ; 1987. Biogeografia e meio ambiente. Rio Claro, Graff Set, 275

p.

UNESCO/WHO/UNEP; 1992. Water Quality Assessments; Chapman and Hall, Londres. 566p. 
Viola, Eduardo J.; 1991. A problemática ambiental no Brasil (1971-1991): da proteção ambiental ao desenvolvimento sustentável. Ed. Polis. 119p. 


\section{ANEXO 1}

\begin{tabular}{|c|c|c|c|c|c|c|c|c|c|c|c|c|}
\hline \multicolumn{13}{|c|}{$\begin{array}{l}\text { PRECIPTAÇÃO FAZENDA CAVALOS }(\mathrm{mm}) \\
\text { COPASA - MG }\end{array}$} \\
\hline ANOS/M & & fev & mar & $a b r$ & mai & jun & jul & ago & set & out & nov & dez \\
\hline 1986 & 307,1 & 144,4 & 110,3 & 46,6 & 55,1 & 8,4 & 22,2 & 43,1 & 0 & 8,4 & 94,8 & 433,1 \\
\hline 1987 & 171,3 & 133,6 & 201,2 & 73,4 & 20,8 & 52,6 & 7,6 & 3,7 & 76,2 & 140,2 & 178,8 & 522,5 \\
\hline 1988 & 190,4 & 232,2 & 192,2 & 175,8 & 39,7 & 3 & 0 & 0 & 40,6 & 118,8 & 119,6 & 290 \\
\hline 1989 & 65,8 & 332,5 & 190 & 12,4 & 9,2 & 34,6 & 41 & 35 & 65 & 120,5 & 264,7 & 387,2 \\
\hline 1990 & 174,1 & 138,2 & 138,2 & 38,8 & 74,4 & 0 & 33,2 & 52,2 & 33,2 & 43,2 & 141,4 & 134,4 \\
\hline 1991 & 625,4 & 88,4 & 249,6 & 64,6 & 5,5 & 0 & 3,6 & 0 & 46,6 & 109,2 & 121,3 & \\
\hline 1992 & 367 & 227 & 87,4 & 49,8 & & 0 & 0 & 12,8 & 107,2 & 101,2 & 149,4 & 470,8 \\
\hline 1993 & 286,8 & 215,2 & 66 & 139,8 & 6,6 & 32,4 & & 7,4 & 83,4 & 59 & 196,8 & \\
\hline 1994 & 430,2 & 26,4 & 367,4 & 33,6 & 99,7 & 9,6 & 0 & 0 & 5,6 & 49 & 164 & 468 \\
\hline 1995 & 162,4 & 227,8 & 267,4 & 81,8 & & 3,6 & 0 & 0 & $\{06,4$ & 0 & 199,6 & 423,2 \\
\hline 1996 & 351,6 & 159,4 & 111,6 & 20 & 26,4 & 2,8 & 18,8 & 23,1 & 77,6 & 66 & 384,3 & 429,5 \\
\hline 1997 & 430,2 & 99,2 & 203,7 & 109,6 & 39,2 & 43,6 & 3,4 & 2,6 & 117,2 & 73 & 137,6 & 355,2 \\
\hline 1998 & 347 & 251,6 & 57 & 29,2 & 71,6 & 1 & 0 & 36,7 & 2 & 137,6 & 268,4 & 175,8 \\
\hline
\end{tabular}

\section{TEMPERATURA MÉDIA FAZENDA CAVALO (graus Celsius)}

COPASA - MG

\begin{tabular}{|c|c|c|c|c|c|c|c|c|c|c|c|c|}
\hline & jan & fev & mar & abr & mai & jun & jul & ago & set & out & nov & dez \\
\hline 1985 & 20,8 & 23,3 & 22,2 & & 18,0 & & 13,7 & 16,9 & 19,6 & 21,6 & 22,5 & 21,2 \\
\hline 1986 & 22,7 & 22,6 & 22,5 & 21,3 & 19,1 & 15,0 & 16,0 & 17.6 & 18,2 & 22,4 & 22,6 & 22,6 \\
\hline 1987 & 23,6 & 24,0 & 23.4 & 21,2 & 20,5 & 16,7 & 16,4 & 18,4 & 20,2 & 24,0 & 23,5 & 21,3 \\
\hline 1988 & 23,8 & 22,9 & 22.7 & 22,1 & 19,4 & 16,7 & 14,7 & 16,4 & 19,5 & 21,0 & 21,6 & 22,2 \\
\hline 1989 & 23,6 & 22,9 & 22,8 & 22,7 & 18,7 & 17,2 & 15,3 & 18,4 & 21,5 & 21,8 & 21,5 & 21,7 \\
\hline 1990 & 23,5 & 23,3 & 24,2 & 22,0 & 17,9 & 16,2 & 16,7 & 16,6 & 18,3 & 21,8 & 23.6 & 23,2 \\
\hline 1991 & 22,0 & 23,4 & 22,5 & 20,8 & 17,5 & 15,3 & 15,4 & 17,9 & 19,6 & 19,6 & 23,1 & 22,0 \\
\hline 1992 & 22,2 & 21,3 & 21,6 & 21,8 & & 16,6 & & 17.6 & 19,8 & 21,0 & 24,4 & 21,8 \\
\hline 1993 & 22,7 & 22,3 & 22,7 & 22,3 & 17,6 & 15.5 & & 20,7 & 20,2 & 21,7 & 22,6 & \\
\hline 1994 & 22,5 & 23,9 & 22.4 & 21,5 & 19,8 & 16,8 & 16,1 & 16.7 & 19,5 & 21,9 & 22,1 & 22,9 \\
\hline 1995 & 23,7 & 23,2 & 22,7 & 21,8 & & 17.5 & 17,2 & 18,9 & 23,4 & & 21,4 & 22,7 \\
\hline 1996 & 23,1 & 23,4 & 23,3 & 21,6 & 18,2 & 16,5 & 17,3 & 18,0 & 19,9 & 22,2 & 22,9 & 23,0 \\
\hline 1997 & 23,3 & 23,5 & 22,9 & 22,1 & 20,4 & 19,0 & 19,2 & 20,1 & 23,5 & & 24,8 & 24,7 \\
\hline 1998 & 25,0 & 25,5 & 25.3 & 24,3 & 21,2 & 18,8 & 19,6 & 21.8 & 23,2 & 23.0 & 23,1 & 24,6 \\
\hline
\end{tabular}


ANEXO 2 - BACIA DO RIBEIRAOO SERRA AZUL

AMOSTRAAGEM DE QUALIDADE DA AGUA - BACIA DO RIBEIRAO SERRA AZUL
TABELA DE DADOS BRUTOS OE 1985.1994
Fonto: COPASA (MG)

\begin{tabular}{|c|c|c|c|}
\hline Data & Hora & $\begin{array}{l}\text { Tempera- } \\
\text { tura }\left({ }^{\circ} \mathrm{C}\right)\end{array}$ & Cor (UPT) \\
\hline 7/jan/85 & $10: 15$ & 22,5 & 75 \\
\hline 25//av/85 & $10: 35$ & 23,0 & 150 \\
\hline S/mar/g5 & $10: 30$ & 23.0 & 100 \\
\hline 2/atros & $10: 30$ & 22,0 & so \\
\hline 20 mai/85 & $11: 05$ & 17,0 & 40 \\
\hline 18/jun/85 & $10: 40$ & 13.0 & 3 \\
\hline $237 / \mathrm{jul} / \mathrm{d} 5$ & $10: 20$ & 17.5 & 20 \\
\hline 26/ago/85 & $13: 30$ & $\$ 9,0$ & 15 \\
\hline 16/saU8S & $11: 55$ & 17.5 & 20 \\
\hline 28/out/85 & $16: 45$ & 22,0 & 50 \\
\hline 19/nov/85 & $15: 35$ & 25,0 & 25 \\
\hline tb/dez/85 & $14: 10$ & 23.0 & 30 \\
\hline 15fjan/86 & $17: 05$ & 22.5 & 150 \\
\hline 17/ffev/BG & 16:55 & 23,0 & 60 \\
\hline $17 / m a r / 86$ & 16:05 & 25,0 & 40 \\
\hline $14 / a b r / 86$ & $16: 35$ & 24,0 & 45 \\
\hline $12 /$ mai $/ 86$ & 15:15 & 21.0 & 65 \\
\hline 17//un/86 & $15: 40$ & 17,5 & 15 \\
\hline 15/jut/86 & $15: 58$ & 15.5 & 10 \\
\hline $14 /$ ago/86 & $14: 40$ & 18.0 & 15 \\
\hline $15 /$ set/86 & $15: 30$ & 19,0 & 20 \\
\hline 13/out86 & $16: 15$ & 23,0 & 30 \\
\hline 20/nov/86 & $13: 10$ & 21.0 & 40 \\
\hline $16 / d e z / 86$ & $14: 30$ & 27,0 & 200 \\
\hline 13/jan/87 & $12: 40$ & 32,0 & 70 \\
\hline 16flev/8? & $12: 50$ & 25.5 & 60 \\
\hline $16 /$ mar/B7 & $12: 10$ & 22.5 & 70 \\
\hline $9 / a b r f 87$ & $11: 40$ & 23,0 & \\
\hline $11 / \mathrm{mai} / \mathrm{g} 7$ & $11: 30$ & 20.5 & \\
\hline 8fjun/87 & $12: 00$ & 18.5 & 10 \\
\hline 14/fu//87 & $11: 30$ & 17.5 & 15 \\
\hline 11/ayo/87 & $13: 20$ & 17,5 & 20 \\
\hline $1 / 4 / \mathrm{se} / 37$ & 13:16 & 20,0 & 50 \\
\hline $20 / 0 u 487$ & $12: 00$ & 23.0 & 60 \\
\hline $17 /$ mov/87 & $13: 10$ & 23.0 & \\
\hline 13/jan/98 & $12: 10$ & 23.0 & 150 \\
\hline $18 / \mathrm{jan} / 88$ & $12: 00$ & 24,0 & 75 \\
\hline $26 f$ an/88 & $12: 20$ & 25.0 & 100 \\
\hline $18 f f a v / B 8$ & $11: 40$ & 23,0 & 70 \\
\hline W/inart $8 B$ & $12: 50$ & 25.0 & 60 \\
\hline $25 / a b r / 88$ & $12: 55$ & 28.0 & 100 \\
\hline $17 / \mathrm{mai} / 88$ & $12: 45$ & 19.5 & 60 \\
\hline 20j)unfag & $12: 40$ & $\$ 40$ & 50 \\
\hline $18 / j$ it/88 & $12: 00$ & 15.0 & 45 \\
\hline 16/ago/83 & $12: 30$ & 14.5 & 30 \\
\hline $19 / \mathrm{suv} 88$ & $12: 50$ & 20,5 & 50 \\
\hline 2Binov/BB & $12: 45$ & 22.0 & 50 \\
\hline 12/40z/88 & $12: 30$ & 23.0 & 60 \\
\hline 16 ijan 89 & $15: 10$ & 25,0 & 20 \\
\hline 23/fov/89 & $13: 45$ & 23,0 & 80 \\
\hline $28 / \ln 3 / 89$ & $12: 25$ & 23.5 & 60 \\
\hline 10/abr/89 & $12: 50$ & 24,5 & so \\
\hline 10/maif89 & $12: 50$ & 18,0 & \\
\hline Sfjun $/ 89$ & $12: 00$ & 19.5 & 40 \\
\hline 3fjul/89 & nos & 17.5 & 30 \\
\hline 1/ago/89 & $11: 35$ & 18.0 & 5 \\
\hline 4/sel/89 & $11: 20$ & 18.0 & 40 \\
\hline 2/outs9 & $14: 20$ & 18.5 & 70 \\
\hline 16/nov/89 & $12: 05$ & 21.0 & 70 \\
\hline $4 / 102 / 89$ & $12: 15$ & 23,0 & 70 \\
\hline $2 / \mathrm{jan} / 30$ & $14: 10$ & 24,0 & 60 \\
\hline $5 / f a v / 90$ & 12:10 & 220 & 100 \\
\hline $12 /$ mat $/ 90$ & $12: 15$ & 24.0 & 50 \\
\hline $2 / a b+/ 90$ & $11: 45$ & 23,0 & 60 \\
\hline $\mathrm{n} / \mathrm{jun} / 90$ & $12: 22$ & 18.5 & 50 \\
\hline $2 / \mathrm{ju} / \mathrm{ho}$ & $12: 05$ & 18.0 & 30 \\
\hline 29/aģo/90 & $11: 10$ & 18.5 & 50 \\
\hline 10/sev9o & $11: 30$ & 19.5 & 60 \\
\hline totoutso & $13: 20$ & 22.5 & 50 \\
\hline 21/mov/90 & $13: 00$ & 23,0 & 100 \\
\hline $3 /$ dez/90 & $15: 00$ & 22.5 & 50 \\
\hline $3 / \mathrm{jan} / 91$ & $16: 20$ & 24.5 & 65 \\
\hline t/marig1 & $12: 30$ & 24,5 & 200 \\
\hline V/abr/91 & 12: 15 & 25.0 & 80 \\
\hline 9/mai/91 & $13: 45$ & 23.0 & 40 \\
\hline $6 / j \tan / 91$ & $11: 20$ & 17.5 & 20 \\
\hline / Holly & $10: 00$ & 17.0 & 50 \\
\hline 27/ago/91 & $09: 45$ & 13.0 & 50 \\
\hline 10/seter & 1000 & 16.5 & so \\
\hline 3/out91 & $14: 15$ & 23.5 & 80 \\
\hline Thovig1 & 13:30 & 20.0 & 100 \\
\hline 10/dez/91 & $11: 50$ & 24.0 & 100 \\
\hline 9fan 92 & $09: 50$ & 23.0 & 250 \\
\hline 12/ev/92 & $10: 30$ & 22,5 & 90 \\
\hline 9/חar/92. & $10: 10$ & 23.5 & 90 \\
\hline 1/abr/92 & $12: 25$ & 23,0 & 80 \\
\hline 4/mai/92 & $11: 50$ & 23.0 & 70 \\
\hline $2 f j u n / 92$ & $09: 10$ & 19.0 & 50 \\
\hline $22 / \mathrm{jw} / 92$ & $09: 20$ & $\$ 5.5$ & 50 \\
\hline 8fagof92 & $09: 50$ & 25.0 & so \\
\hline 14/4sel/82 & $03: 50$ & 19.5 & 70 \\
\hline 13rouv92 & $10: 40$ & 21,0 & 60 \\
\hline O/nov/92 & $11: 50$ & 21.5 & 100 \\
\hline 9/dez/92 & 10:15 & & 60 \\
\hline
\end{tabular}




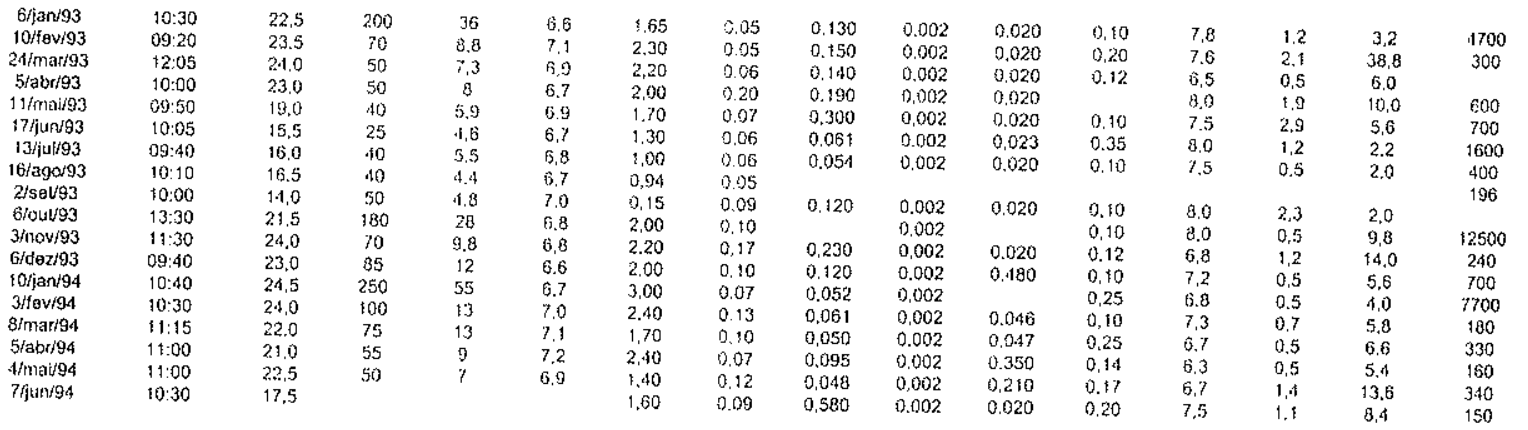

\begin{tabular}{|c|c|c|c|c|c|c|c|c|c|c|c|c|c|c|c|}
\hline Eslatistica Descritiva & Qide resultado & 111 & 107 & 108 & 107 & 112 & 111 & 102 & 48 & 96 & 45 & 105 & 97 & 46 & 63 \\
\hline \multirow{4}{*}{ Paramotrica } & Media & 21.2 & 66.1 & 14.0 & 6.6 & 1,83 & 0.10 & 0,099 & 0,002 & 0,077 & 0,16 & 7.2 & 1.0 & 10.0 & 1042.4 \\
\hline & Med. Geometric & 20,9 & 53,6 & 10,3 & 6.6 & 1.62 & 0.09 & 0.062 & 0.002 & 0.017 & 0.15 & 7,1 & 0,7 & 6.7 & 227,0 \\
\hline & Moda & 23,0 & 50.0 & 10.0 & 6.6 & 1.70 & 0.05 & 0.120 & 0.002 & 0,020 & 0,10 & 6.7 & 0.5 & 2.0 & 180,0 \\
\hline & $\begin{array}{l}\text { Oesvio Padrào } \\
\text { Couf. Variaçảo }\end{array}$ & $\begin{array}{l}3.3 \\
0.2\end{array}$ & $\begin{array}{r}45.9 \\
0.7\end{array}$ & 15.9 & 0.4 & 0,86 & 0.08 & 0,097 & 0.001 & 0.310 & 0.09 & 0.8 & 0.8 & 12.6 & 3280,3 \\
\hline \multirow{5}{*}{ Não.Paramótrica } & Minimo & 130 & 3.0 & $\frac{1,1}{2.5}$ & $\frac{0,1}{5,4}$ & 0,5 & 0.8 & $\frac{1,0}{0.001}$ & 0,3 & 4,0 & 0.5 & 0.1 & 0,8 & 1,3 & 3,1 \\
\hline & Quartili 1 & 18.5 & 40.0 & b. 3 & 6,4 & $\begin{array}{l}0,10 \\
130\end{array}$ & 0.05 & 0.001 & 0.001 & 0.001 & 0,10 & 4.7 & 0.1 & 2,0 & 10,0 \\
\hline & Mediana & 22.5 & 55.0 & 9,0 & 0.6 & $\begin{array}{l}1,30 \\
170\end{array}$ & 0.06 & 0,040 & 0,002 & 0.004 & 0.10 & 6.7 & 0.5 & 1,0 & 98.0 \\
\hline & Quartil 3 & 23.0 & 75,0 & 140 & 6.9 & 2.26 & 0.09 & 0.068 & 0,002 & 0.020 & 0.12 & 7.2 & 0.7 & 6,0 & 180,0 \\
\hline & Máximo & 32,0 & 250,0 & 97.0 & 81 & $\begin{array}{l}1.20 \\
700\end{array}$ & 0.11 & 0.120 & 0,002 & 0.045 & 0,20 & 7.7 & 1,3 & 10.6 & 505.0 \\
\hline
\end{tabular}


ANEXO 2 - BACIA DO RIBEIRÄO SERRA AZUL

AMOSTRAGEM DE QUALIDADE DA AGUA - BACIA DO RIBEIRAO SERRA AZUI
TABELA OE DADOS BRUTOS DE 1985-1994
Eonte:COPASA IMG:

\begin{tabular}{|c|c|c|c|c|c|c|c|}
\hline Dato & Hora & $\begin{array}{l}\text { Tempera. } \\
\text { tura }\left({ }^{\circ} \mathrm{C}\right)\end{array}$ & Cor (UPT) & \begin{tabular}{|c|} 
Turbidez \\
(NrU)
\end{tabular} & $\mathrm{pH}$ & $\begin{array}{c}F_{\theta} \text { totaf } \\
\text { (mg/t } F_{\theta \theta}\end{array}$ & $\mid \begin{array}{c}\text { Mn totai } \\
(\mathrm{mg} / \mathrm{Mn})\end{array}$ \\
\hline 7/fan/as & $10: 40$ & 23,0 & 500 & $\begin{array}{l}140 \\
199\end{array}$ & 5,6 & 2,17 & 0.29 \\
\hline $\begin{array}{l}25 / f \text { ev/85 } \\
5 / \operatorname{mar} / 85\end{array}$ & $11: 30$ & 24,0 & 150 & $: 9$ & 6.9 & 2,00 & 0.28 \\
\hline $\begin{array}{l}5 / \mathrm{mar} / 85 \\
2 / \mathrm{abr} / 85\end{array}$ & $11: 35$ & 23.0 & 100 & 24 & 6,7 & 2,40 & 0.25 \\
\hline & $11: 20$ & 23,0 & 100 & 30 & 6.8 & 2,60 & 0.26 \\
\hline $\begin{array}{l}20 / \text { maif85 } \\
18 / \text { un } 85\end{array}$ & $11: 45$ & 19.5 & 20 & 6 & 6.4 & 1.20 & 0.26 \\
\hline 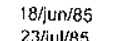 & $11: 15$ & 16,0 & 25 & 5.9 & 5.4 & 0.92 & 0.22 \\
\hline 23 /jul/85 & $12: 00$ & $\$ 8,0$ & 30 & 7 & 6.4 & 1,10 & 0.27 \\
\hline 26fago/85 & $\$ 00$ & 21.0 & 30 & 18 & 6.8 & 1,10 & 0,36 \\
\hline $16 /$ setv85 & $12: 30$ & 99.0 & 30 & 8 & 6.4 & 1,30 & 0.22 \\
\hline 28/outu85 & $15: 55$ & 24,0 & 50 & 9 & 6.8 & 1.30 & 0.14 \\
\hline $19 /$ hov/85 & $15: 00$ & 24,0 & 60 & 10 & 6,8 & 1,50 & 0.19 \\
\hline 16/dezj85 & $13: 20$ & 23.5 & 40 & 16 & 6,7 & 1.50 & 0.16 \\
\hline 15/jan/86 & $16: 30$ & 22,0 & 100 & 70 & 6.6 & 6,00 & 0.13 \\
\hline $17 / / 6 v / 86$ & $16: 05$ & 23.0 & 180 & 6.1 & 6,5 & 7,70 & 0.16 \\
\hline $17 /$ mar/86 & $15: 10$ & 25.0 & 18 & 15 & 6.6 & 1.30 & 0.18 \\
\hline Th/abr/8g & $15: 56$ & 24,0 & 20 & 10) & 6.5 & 1.80 & 0.23 \\
\hline I2/mair86 & $14: 45$ & 23.0 & 55 & 40 & 8.3 & 2.90 & 0.17 \\
\hline 17/jun/86 & 15:05 & 19.0 & 15 & 7 & 6.4 & 0.76 & 0.13 \\
\hline $15 f$ wi/g6 & $15: 28$ & 17,5 & 10 & 7.5 & 6,5 & 1,10 & 0.17 \\
\hline 14/ago/86 & $14: 00$ & 20.5 & th & 9 & 6. 8 & 1,80 & 0.20 \\
\hline $15 /$ sott86 & $15: 0.4$ & 21.5 & 40 & 10 & 6.7 & 1.40 & 0.17 \\
\hline $13 / 0 u+86$ & $15: 35$ & 23,0 & 10 & 6.6 & 6,3 & 1,40 & 0.16 \\
\hline $20 /$ nov/86 6 & $12: 30$ & 20.5 & 50 & 12 & 6.5 & 1.10 & 0.20 \\
\hline โ6/dez/86 & 13:45 & 26.0 & 150 & 65 & 6.6 & 1,40 & 0.22 \\
\hline $13 f$ an $/ B 7$ & $12: 00$ & 29.0 & 70 & 18 & 6.5 & 1.40 & 0,30 \\
\hline $16 / f$ ev/87 & $12: 15$ & 23.0 & 40 & 16 & 6.3 & 1.40 & 0.20 \\
\hline 16/mar/87 & $11: 30$ & 23,0 & 70 & 32 & 6.2 & 1.20 & 0,77 \\
\hline $9 / a b t / 87$ & $11: 05$ & 22,5 & so & 10 & 6.1 & 1.50 & 0.13 \\
\hline 11/mai/g7 & $10: 40$ & 20,0 & & 8.5 & 6.2 & 1,60 & 0.21 \\
\hline 8/un/87 & $11: 30$ & 20.5 & 30 & 6.6 & 6.14 & 1.20 & 0.19 \\
\hline $14 / j \mathrm{jul} / 87$ & $10: 50$ & 18.5 & 60 & 14 & 0.4 & 1.00 & 0.19 \\
\hline 14tago/87 & $12: 40$ & 19.0 & 50 & 10 & 6.7 & 1.00 & 0.24 \\
\hline $14 / \mathrm{sev} 87$ & $12: 35$ & 21.0 & 50 & 3,5 & 6.7 & 1.10 & 0.21 \\
\hline 20/out/87 & $11: 25$ & 23.5 & 70 & 13 & 6.8 & 1.50 & \\
\hline t7/hovts7 & $12: 35$ & 220 & & & & $: .70$ & 0.19 \\
\hline 13/jan/88 & $11: 25$ & 23.0 & 100 & 87 & 6.5 & 1.40 & 0.20 \\
\hline ty/jan/8g & $11 \cdot 10$ & 23.5 & 70 & 20 & 0.9 & 1,90 & 0.35 \\
\hline 26 tjan/88 & $11: 27$ & 24.0 & 70 & 2.4 & 7.0 & 2.20 & 0.42 \\
\hline $18 / f_{\text {ev }} / 88$ & $12: 20$ & 25.0 & 200 & 50 & 6.6 & 1.37 & 0.28 \\
\hline W/fmar/98 & $13: 31$ & 24.0 & 40 & 9.5 & 6.3 & 1.55 & 0.19 \\
\hline 25/abs/dad & $12: 10$ & 19.0 & 120 & 6.8 & 6.7 & 1.10 & 0.2 .1 \\
\hline $17 /$ mairg8 & $12: 15$ & 21.0 & 50 & 5.7 & 6.7 & 1.20 & 0.27 \\
\hline $20 / 13 n / 88$ & $12: 20$ & 16.0 & 60 & 3.6 & 6.8 & 1,00 & 0,19 \\
\hline $18 / j u / 88$ & $11: 30$ & 16.0 & 45 & $B$ & 5.6 & 1.20 & 0.22 \\
\hline 16/ago/es & $11: 50$ & $\$ 5.0$ & 10) & 6.4 & 6.5 & 1.30 & 0.22 \\
\hline $19 / 50188$ & $: 2: 00$ & 20.5 & 60 & 6.2 & 0.7 & 1.30 & 0.24 \\
\hline $28 / n o v / 8 B$ & $12: 15$ & 24,0 & 6.5 & 8.5 & 7.1 & 1,30 & 0.06 \\
\hline $12 / d \theta Z / 88$ & $11: 50$ & 24.5 & 70 & $2 ?$ & 6.9 & 1.70 & 0.21 \\
\hline to/jan/89 & $14: 30$ & 25,0 & 70 & $\$ 9$ & 7.2 & 1.60 & 0.20 \\
\hline $23 / 6 v / 89$ & $34: 30$ & 24.0 & 90 & 12 & 7.0 & 2.00 & 0,20 \\
\hline $28 / m a r / 89$ & $11: 50$ & 23,5 & 50 & 13 & 6.9 & 1.70 & 0.25 \\
\hline 10/abr/99 & $12: 14$ & 23.5 & 10 & 7.2 & 6.8 & 8.40 & 0.20 \\
\hline 3/jul/89 & $13: 25$ & 18.0 & 50 & 5.2 & 6.6 & 1.20 & 0.20 \\
\hline 16 mov/89 & 11.25 & 21.5 & 70 & 11 & & 1,60 & 0.20 \\
\hline 4/lez/89 & $11: 11$ & 22.0 & 70 & 15 & 6.8 & 1.55 & 0.40 \\
\hline 2 Jan/90 & 13:20 & 22.5 & 90 & 50 & 6.9 & 1.52 & 0.10 \\
\hline $5 / f o v / 90$ & $10: 40$ & 23,0 & 100 & $g$ & 6.9 & 1.17 & 0.15 \\
\hline 12 mari9o & 11.50 & 25.0 & 40 & 10 & 6.8 & 1.78 & 0.27 \\
\hline 2/abr/90 & $11: 20$ & 23.0 & 30 & 8.7 & 6.9 & 1,78 & 0.20 \\
\hline $4 / 40 \mathrm{~m} / 90$ & 1150 & $\$ 9.0$ & 60 & 7.5 & 7,0 & 1.50 & 0.21 \\
\hline $2 / j u / / 90$ & $11: 40$ & 19.0 & 40 & 10 & 7.1 & 1.96 & 0.23 \\
\hline 29 ago/9o & $10: 35$ & 18,0 & 40 & a & 7.0 & 1,00 & 0,05 \\
\hline 10/set9o & $11: 05$ & 20.0 & 40 & 10 & 6.8 & 1.88 & 0.27 \\
\hline 10loutt90 & $12: 35$ & 24.5 & 10 & 15 & 7.2 & 1,90 & 0.10 \\
\hline 211nov/90 & $12: 25$ & 24.5 & 70 & 12 & 6.9 & $t .00$ & 0.05 \\
\hline $3 /$ dez/so & $14: 30$ & 23.0 & 70 & 10 & 6.5 & 1.62 & 0.17 \\
\hline $1 / 701 / 91$ & $10: 35$ & 18.0 & 50 & 6.5 & 6.9 & 1.30 & 0.19 \\
\hline 27tagof 91 & 10:15 & 13.0 & 60 & 3.3 & 7.2 & 1.53 & 0.19 \\
\hline 10/sev9t & $10: 25$ & 170 & 80 & 10 & 7.0 & 1.42 & 0.20 \\
\hline 3fout/91 & $14: 50$ & 23.5 & 250 & 71 & 6.5 & 7.50 & 0.09 \\
\hline 4/10v/91 & $1+40$ & 23.0 & 80 & 14 & 7.1 & 1.60 & 0.10 \\
\hline 10/dezfo1 & $12: 25$ & 23.5 & 140 & 2.4 & 7,0 & 3.00 & 0.06 \\
\hline 9flan/92 & 11) 20 & 23.5 & 350 & 30 & 7.2 & 3.40 & 0,44 \\
\hline f2/fev/92 & $10: 50$ & 23.5 & 70 & is & 6.9 & 2,40 & 0.19 \\
\hline $9 / \mathrm{mar} / 92$ & $10: 30$ & 24.5 & (5i) & 9.5 & 6.7 & 1.50 & 0.16 \\
\hline 1/abri92 & $12: 50$ & 24.5 & 50 & 9.2 & 6.3 & 1.50 & 0.12 \\
\hline 4/mai/92 & $12: 40$ & 22.5 & 50 & 7.5 & 7.4 & 3,00 & 0.16 \\
\hline 2/jun/92 & $09: 40$ & 19.5 & 10 & 5 & 6.9 & 1.00 & 0.14 \\
\hline $22 / \mathrm{ju} / \mathrm{s} 2$ & $09+40$ & $\$ 6.5$ & 50 & is & 6.8 & 1.30 & 0.20 \\
\hline 18/ago/92 & 10:15 & 18.0 & 50 & 6.6 & 72 & 1.00 & 0.20 \\
\hline $14 / \mathrm{seV} 92$ & $10: 30$ & 19.0 & 40 & 4.4 & 7.0 & 8.10 & 0.08 \\
\hline 13 louv92 & $11: 05$ & 22.0 & 70 & 10 & 7.0 & 2.70 & 0.29 \\
\hline 10/nov/92 & 1250 & 22.5 & 140 & 30 & 6.3 & 3.20 & 0.12 \\
\hline 9/4eaz/92 & $10: 50$ & & 90 & in & 68 & 6.20 & 0.22 \\
\hline 6/jan/93 & 1100 & 23.0 & 150 & 35 & 7.2 & 2,00 & 0.12 \\
\hline $0 / f \circ$ vig3 & $09: 40$ & 23.5 & 30 & 12 & 6.9 & 2.80 & 0.12 \\
\hline W/mar 93 & $12: 35$ & 24.0 & 60 & 8.4 & 7.4 & 2,40 & 0.12 \\
\hline 5fabrig3 & $10: 30$ & 22.5 & 55 & 8.8 & 6.8 & 1.40 & 0,14 \\
\hline 1/mair93 & $10: 20$ & 19.0 & 45 & 6.5 & 6.3 & 1.20 & 0.17 \\
\hline $7 f \mathrm{f}(\mathrm{n} / 93$ & $10: 40$ & 8,5 & 45 & 6.4 & 7.0 & 1.20 & 0.13 \\
\hline
\end{tabular}




\begin{tabular}{|c|c|c|c|c|c|c|c|c|c|c|c|c|c|c|c|}
\hline $13 / 2 w / 93$ & $10: 10$ & $: 6.5$ & 45 & 6.5 & & 130 & & & & & & & & & \\
\hline $16 / \mathrm{ago} / 93$ & $10: 40$ & 16.5 & 60 & 7 & 6.8 & 1.75 & $\begin{array}{l}0.17 \\
0.18\end{array}$ & 0.210 & 0.002 & 0.020 & 0.10 & 8.1 & 1,3 & 6.6 & 370 \\
\hline $2 / s e t 93$ & $10: 30$ & 23.5 & 60 & 6.7 & 6,8 & 0.20 & $\begin{array}{l}0.18 \\
0.25\end{array}$ & 0.140 & 0.002 & 0.020 & 0.20 & 7.1 & 1.1 & 5.4 & 580 \\
\hline Glout93 & 1100 & 21.5 & 100 & is & 7.0 & 2,00 & $\begin{array}{l}0.25 \\
0.14\end{array}$ & 0,120 & 0,002 & 0.020 & 0.20 & 7,0 & 0.5 & 20.6 & 3000 \\
\hline $3 / n$ ov/93 & $12: 30$ & 26.0 & 70 & 10 & 6,8 & 2.20 & & 0.2 .30 & 0.002 & 0.020 & 0.10 & 6.5 & 0.5 & 12,2 & 196 \\
\hline $6 /$ tez $/ 93$ & $10: 00$ & 22.5 & 75 & 9.1 & 6.6 & 2,30 & $\begin{array}{l}0.27 \\
0.22\end{array}$ & 0.020 & 0,002 & 0.026 & 0.13 & 6.5 & 0.5 & 2.2 & 650 \\
\hline 10 fan 94 & $11: 10$ & 24.0 & 800 & 150 & 7.0 & 0.50 & & 0.0 .46 & 0.002 & 0.300 & 0.35 & 6.8 & 3,9 & 502,0 & \\
\hline $3 / f e v / 94$ & $11: 00$ & 23.0 & 70 & 13 & 7.0 & 240 & $\begin{array}{l}0.40 \\
033\end{array}$ & 0,120 & 0.002 & 0050 & 0.43 & 6.3 & 6.3 & 21,4 & \\
\hline 8/mar/94 & $11 \cdot 40$ & 21.5 & 120 & 22 & 7.0 & 1.30 & $\begin{array}{l}0.33 \\
0.18\end{array}$ & 0.058 & 0.0012 & 0.160 & 0.28 & 7.3 & 1.4 & 51,2 & \\
\hline $5 / a b r 194$ & $11: 20$ & 21.0 & 60 & 11 & 7,3 & 130 & $\begin{array}{l}0.18 \\
0.15\end{array}$ & 0.300 & 0.002 & 0.023 & 0.20 & 6.8 & 0.5 & 28.0 & \\
\hline 4/mai/s4 & $11: 40$ & 21,0 & 45 & 0.9 & 7.0 & 1.50 & $\begin{array}{l}0.15 \\
0.16\end{array}$ & 1.600 & 0.002 & 0.020 & 0.10 & 7,0 & 1,7 & 26,8 & \\
\hline
\end{tabular}

\begin{tabular}{|c|c|c|c|c|c|c|c|c|c|c|c|c|c|c|c|}
\hline Estaltslica Descriliva & Qlde resul & 100 & 99 & 100 & 99 & 101 & 100 & 96 & 42 & 90 & 42 & 99 & 93 & 1.3 & 58 \\
\hline \multirow{4}{*}{ Paramétrica } & Media & 21.6 & 80.7 & 19,4 & 8.8 & 1.89 & 0.21 & 0,135 & 0,007 & 0.041 & 0.27 & 7.4 & 1.5 & 44,2 & 1896,0 \\
\hline & Med. Geon & 21.5 & 50.6 & 13.1 & 6.8 & 1,63 & 0.19 & 0.053 & 0,002 & 0.018 & 0.17 & 7,3 & 1,0 & 13.2 & 685.5 \\
\hline & $\begin{array}{l}\text { Moda } \\
\text { Desvio pa }\end{array}$ & 23,0 & 10,0 & 10.0 & 6.8 & 1.30 & 0.20 & 0,001 & 0.002 & 0,020 & 0.10 & 7.3 & 0.5 & 4,6 & 480,0 \\
\hline & $\begin{array}{l}\text { Desvio Pat } \\
\text { Coef. Varia }\end{array}$ & $\begin{array}{l}2.8 \\
0.1\end{array}$ & 97,8 & $\begin{array}{c}24.8 \\
1.3\end{array}$ & $\begin{array}{l}0.3 \\
0.0\end{array}$ & $\begin{array}{l}1,40 \\
07\end{array}$ & 0.10 & 0.212 & 0.031 & 0.061 & 0.46 & 1.0 & 1.5 & 126.3 & 4623,0 \\
\hline \multirow{5}{*}{ Nảo-Paramótrica } & Mínimo & 15,0 & 10,0 & 4.4 & 6.1 & $\frac{9,1}{0,20}$ & $\frac{0,5}{0,05}$ & $\frac{1.6}{0.001}$ & 4,3 & 1,5 & 1,7 & 0,1 & 1.0 & 2.9 & 24 \\
\hline & Ouartil ! & 10.4 & 40,0 & 7.5 & 6.6 & 1.20 & 0,16 & 0,001 & 0,002 & 0,001 & 0.01 & 0,5 & 0.1 & 2,0 & 53.0 \\
\hline & Mediana & 22.5 & 60,0 & 10.0 & 6.8 & 1,50 & 0.20 & $\begin{array}{l}0,025 \\
0,073\end{array}$ & 0.002 & 0.010 & 0.10 & 7.0 & 0.5 & 5.6 & 304,0 \\
\hline & Quartil 3 & 23,5 & 72,5 & 18.0 & 7.0 & 196 & 0.24 & 0,073 & 0.002 & 0.020 & 0.16 & 7.5 & 0,9 & 9,6 & 570,0 \\
\hline & Máxing & 290 & 800,0 & 150,0 & 74 & 9.50 & 0.77 & $\begin{array}{l}0.170 \\
8.600\end{array}$ & $\begin{array}{l}0.002 \\
0.200\end{array}$ & 0.042 & 0,28 & 7.9 & 1.8 & 25,3 & 1850.0 \\
\hline
\end{tabular}


ANEXO 2 - BACIA DO RIBEIRÃO SERRA AZUL

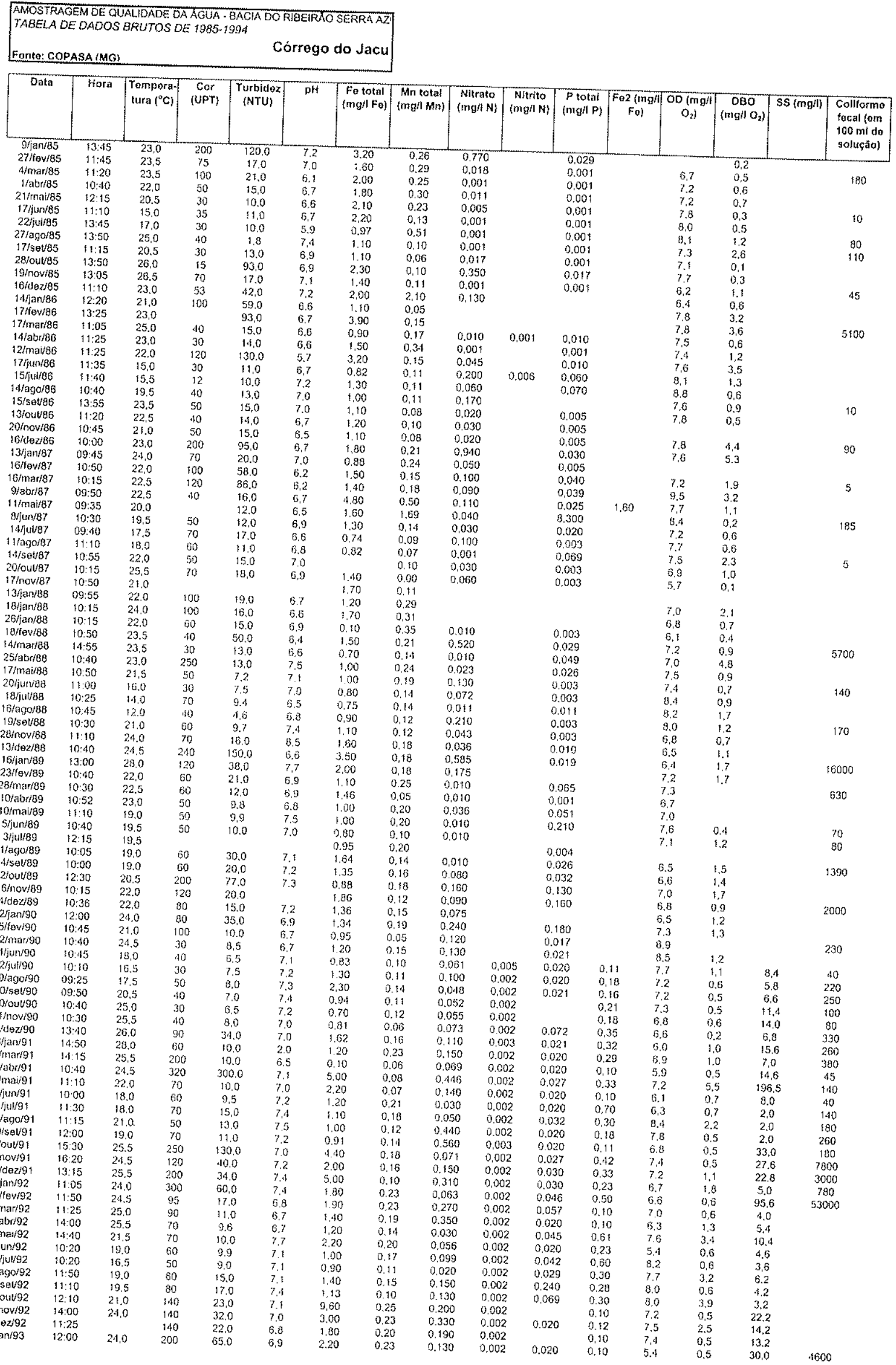




\begin{tabular}{|c|c|c|c|c|c|c|c|c|c|c|c|c|c|c|c|}
\hline $10 / f a v / 93$ & $10: 45$ & 23.5 & 70 & 13,0 & 6.9 & & & 0.020 & 0.002 & 0.020 & 0.58 & 75 & 15 & 5.6 & 420 \\
\hline $24 /$ mar $/ 93$ & $13: 45$ & 26,0 & 60 & 13.0 & 6.9 & 1,80 & 0,15 & 0.078 & 0.002 & 0.020 & 0.30 & 5.9 & 3,5 & 237.0 & 90 \\
\hline $5 / a b r / 93$ & $11: 30$ & 23.0 & 55 & 10.0 & 8.9 & 1.40 & 0.50 & 0.058 & 0.002 & 0.020 & 0.17 & 75 & 2.2 & 51.6 & 90 \\
\hline t 1/mai/93 & $11: 50$ & 20.0 & \$1) & 8,4 & 7.0 & 2,00 & 0.20 & 0,170 & 0.002 & 0.020 & (1) 22 & 7.8 & 0.9 & 4.4 & 90 \\
\hline $17 \mathrm{j} \mathrm{u}, \mathrm{n} / 93$ & $\$ 1: 25$ & 17.5 & 10 & 8.0 & 70 & 1.00 & 0.15 & 0.020 & 0,002 & 0.023 & 0.25 & 6,8 & 1.7 & 86.0 & 10 \\
\hline $13 / \mathrm{fu} / \mathrm{g} 3$ & $11: 10$ & 17.5 & 35 & 7.8 & 7.1 & 0.90 & 0.14 & 0.041 & 0.002 & 0.020 & 0.50 & 2.6 & 2.6 & 9,4 & 10 \\
\hline 16/ago/93 & $11: 40$ & 16,5 & 10 & 7.2 & 7,0 & 3,30 & 0.09 & 0.020 & 0.002 & & 0.15 & 6.5 & 0,8 & 13.4 & 60 \\
\hline $2 / \mathrm{set} / 93$ & $11: 15$ & 17.0 & 70 & 13.0 & 7.9 & 0.28 & 0.10 & & & 0,020 & & & & & 46 \\
\hline S/out/93 & $14: 35$ & 22,0 & 100 & 20,0 & 7,1 & 1,80 & 0.20 & 0.150 & 1),003 & & 0.02 & 7.6 & 0.8 & 6,4 & 1100 \\
\hline 3hov/93 & $14: 05$ & 25,0 & 60 & 9.9 & 7.0 & 1,00 & 0.07 & $0,0.46$ & 0.002 & 0.020 & 0,50 & 7.4 & 2.5 & 16,4 & 310 \\
\hline $6 / d a z / 93$ & $10: 55$ & 23.0 & 30 & 17,0 & 6.9 & 1.26 & 0,09 & 0.034 & 0,002 & 0.480 & 0,10 & 6.2 & 0.5 & 24.8 & 720 \\
\hline $10 /$ Jan $/ 94$ & $12: 45$ & 24.0 & 450 & 94.0 & 7.0 & 3.40 & 0.20 & 0.100 & 0.002 & & 0.12 & 6.7 & 0.5 & 6.8 & 116 \\
\hline 3/favi94 & $12: 00$ & 23.0 & 80 & 15.0 & 7.0 & 2,00 & 0.30 & 0,071 & 0,002 & 0.046 & 0.10 & 6.8 & 1.4 & $m 0$ & 400 \\
\hline 8/mar/94 & $13: 00$ & 22.5 & 80 & 16,0 & 7,0 & 1,30 & 0.23 & 0,046 & 0,002 & 0,047 & 0,12 & 5.8 & 0.5 & 7.2 & 1000 \\
\hline $5 / 3$ bris4 & $13: 20$ & 23.0 & 80 & 16,0 & 7,1 & 1,70 & 0.21 & 0.041 & 0.002 & 0.350 & 0,10 & 5,5 & 0.7 & 11,4 & 48 \\
\hline fimal/94 & $13: 30$ & 22,0 & .15 & 0.5 & 7.1 & 12,00 & 0.16 & 0.190 & 0.002 & 0.210 & 0.10 & 5.8 & 0.5 & 4.4 & 400 \\
\hline 7/) & $13: 00$ & 20,0 & & & & 1.10 & 0.13 & 0.830 & 0.002 & 0.020 & 0.10 & 5.6 & 0.5 & 4,4 & \\
\hline
\end{tabular}

\begin{tabular}{|c|c|c|c|c|c|c|c|c|c|c|c|c|c|c|c|}
\hline Eslatistica Oescritiva & Oaldo. rosu & 110 & 106 & 108 & $10 ?$ & 109 & 110 & 104 & 49 & 94 & $4 B$ & 105 & 102 & 47 & 57 \\
\hline \multirow{4}{*}{ Paramétrica } & Media & 21,6 & 8.1,9 & 27.8 & 6.9 & 1.76 & 0,20 & 0,126 & 0,002 & 0.129 & 0.27 & 7.1 & 1.3 & 23.6 & 1911,7 \\
\hline & Med. Gear & 21,1 & 67.8 & 17.4 & 6.9 & 1,40 & \#NGM! & 0.053 & 0.002 & 0.018 & 0.20 & 7,0 & 1.0 & 10,8 & 207.1 \\
\hline & Moda & 22,0 & 10.0 & 15.0 & 7,0 & 1.10 & 0,14 & 0.010 & 0.002 & 0,020 & 0.10 & 7.2 & 0.5 & 2.0 & 10,0 \\
\hline & $\begin{array}{l}\text { Uesvio Pa } \\
\text { Coef. Varia }\end{array}$ & $\begin{array}{l}3.1 \\
0.1\end{array}$ & $\begin{array}{l}69,7 \\
0,8\end{array}$ & $\begin{array}{c}39,6 \\
1,4\end{array}$ & $\begin{array}{l}0.6 \\
0.1\end{array}$ & $\begin{array}{l}1,56 \\
0,9\end{array}$ & 0.25 & 0,176 & 0.001 & 0.855 & 0,26 & 0.9 & 1,2 & 45.5 & 7340,4 \\
\hline \multirow{5}{*}{ Não-Paramótrica } & Minimo & 12,0 & 12,0 & 1.8 & 2,0 & 0,10 & $\frac{1.2}{0.00}$ & $\frac{1,4}{0,4}$ & 0,3 & 6,6 & 0,9 & 0,1 & 0,9 & 1,9 & 3,8 \\
\hline & Quartia 1 & 19.5 & 11.3 & 10,0 & 6,7 & 1.00 & $\begin{array}{l}0,00 \\
0,11\end{array}$ & $\begin{array}{l}0,001 \\
0,022\end{array}$ & $\begin{array}{l}0.001 \\
0.002\end{array}$ & 0,001 & 0,02 & 2.6 & 0.1 & 2,0 & 5.0 \\
\hline & Mediana & 22.0 & 60.0 & 15.0 & 7.0 & 1.34 & 0,15 & 0.062 & 0.002 & 0.006 & 0.10 & 6,7 & 0.5 & 5.2 & 80,0 \\
\hline & Quartil 3 & 24.0 & 98,8 & 2.1 .0 & 71 & 186 & & & 0,002 & 0.020 & 0.20 & 7,2 & 0,9 & 8,4 & 180.0 \\
\hline & Maximo & 28,0 & 450,0 & 300,0 & 8,5 & 12,00 & $\begin{array}{l}0.21 \\
2.10\end{array}$ & $\begin{array}{l}0,150 \\
0,9.10\end{array}$ & 0.002 & 0.040 & 0.32 & 7.6 & 1.7 & 16,0 & 420,0 \\
\hline
\end{tabular}


ANEXO 2 - BACIA DO RIBEIRÃO SERRA AZUL

AMOSTRAGEMOE OUALIOADE DA AGUA - BACIA DO RIBETRAO SERRA AZZUL
TABELA DE DADOS BRUTOS DE 1985-1994
Fonte: COPASA IMG

\begin{tabular}{|c|c|c|c|c|c|}
\hline Data & Hora & $\begin{array}{l}\text { Tempera- } \\
\text { tura }\left({ }^{\circ} \mathrm{C}\right)\end{array}$ & Cor (UPT) & $\begin{array}{c}\text { Turbidez } \\
\text { (NTU) }\end{array}$ & $\mathrm{pH}$ \\
\hline $7 / \mathrm{jar} / 35$ & $10: 55$ & 24,0 & 10 & 11 & 6.3 \\
\hline 25/lev/85 & $11: 00$ & 24,0 & 75 & 12 & 6.7 \\
\hline Shmar/85 & 11:05 & 23,0 & 100 & 19 & 6,2 \\
\hline 2/abri8s & t0:55 & 23.0 & 100 & 32 & 6.2 \\
\hline 20/mair85 & $11: 23$ & 20.0 & 5 & 2 & 5.3 \\
\hline $18 /$ tun/85 & $10: 58$ & 16,0 & 2 & 4,5 & 6.3 \\
\hline $23 / 9 u / 85$ & $11: 20$ & 18.0 & 20 & 8 & 0,1 \\
\hline 26/agot85 & $13: 50$ & 21.5 & 20 & 13 & 6,7 \\
\hline $16 / 5$ s/85 & 12:14 & 21.5 & 20 & B & 6.5 \\
\hline 28\%ouVBS & $16: 20$ & 25.0 & 40 & 9 & 6.7 \\
\hline 19/now/85 & $15: 20$ & 27,0 & 25 & 10 & 6.7 \\
\hline $16 /$ dez/85 & $13: 45$ & 23.0 & 10 & 14 & 6.4 \\
\hline $15 / j a n / 86$ & $16: 45$ & 23.5 & 100 & 17 & 6.3 \\
\hline 17flev/86 & $16: 30$ & 24,0 & 150 & 15 & 6.0 \\
\hline $17 /$ mar/86 & $15: 25$ & 26,0 & 3 & 10 & 6,6 \\
\hline 1/abr/86 & $16: 15$ & 25.0 & 5 & 13 & 6.5 \\
\hline $12 /$ inaif86 & $15: 00$ & 23.0 & 5 & 4.5 & 6.3 \\
\hline 17fjund86 & $15: 20$ & 20,0 & 15 & 15 & 6.3 \\
\hline $15 / j \mathrm{k} / \mathrm{Bg}$ & $35: 40$ & 18,0 & 10 & 19 & 6.3 \\
\hline 14/ago/86 & $14: 15$ & 21.5 & 30 & 8 & 7.0 \\
\hline 15/sal86 & $15: 15$ & 22.5 & 60 & 23 & 6,4 \\
\hline 13/oulv86 & 16:00 & 24,0 & 20 & 8.7 & 6,3 \\
\hline 20/novi86 & $12: 50$ & 22.0 & 70 & 28 & 6.5 \\
\hline 16/duzt86 & $14: 10$ & 27,0 & 100 & 88 & 6.3 \\
\hline 13/jan/87 & $12: 20$ & 31.0 & 30 & 7 & 6.2 \\
\hline $16 / m a r / 87$ & $11: 50$ & 25.0 & 120 & 120 & 5,9 \\
\hline 9/abri8? & $11: 20$ & 23,0 & 20 & 1.4 & 6.3 \\
\hline 11/mai/87 & $11: 00$ & 20.5 & & 8.5 & 6.3 \\
\hline 8/jun/87 & $11: 45$ & 20.0 & 15 & 10 & 6.2 \\
\hline $14 / j u t / 87$ & $11: 10$ & 19,5 & 40 & 11 & 6.3 \\
\hline 11 ago 187 & $12: 55$ & 20.0 & 20 & i5 & 6.3 \\
\hline $14 /$ sever & $12: 55$ & 23.0 & 10 & 32 & 6.2 \\
\hline $20 /$ out 87 & $11: 45$ & 24.5 & 30 & 24 & 7.0 \\
\hline 17/now/87 & $12: 50$ & 23,0 & & & \\
\hline 13fjant88 & $11: 46$ & 23,0 & 250 & 87 & 6.5 \\
\hline 18/jan/ge & $11: 20$ & 25.0 & 40 & 16 & 6.7 \\
\hline 26/jan/38 & $15: 10$ & $2,4,5$ & 35 & 6.5 & 6.6 \\
\hline 18/lev/88 & 12:00 & 25.0 & 50 & 10 & 6,5 \\
\hline 14/mar/88 & $13: 10$ & 25.5 & 15 & 5 & 6.2 \\
\hline 25/abr/88 & $12: 30$ & 20.0 & 150 & 5.7 & 6.5 \\
\hline 17/mai/8s & $12: 30$ & 21.5 & 20 & 2.6 & 5.2 \\
\hline 20/jun/BB & $12: 30$ & 17,5 & 50 & 5.5 & 6.7 \\
\hline 18/jul/f8 & $11: 40$ & 17.0 & 45 & 8 & 6.5 \\
\hline 16/agot38 & $\{2 ; 10$ & 15.0 & 40 & 11 & 6. 5 \\
\hline $19 / 50$ / 88 & $12: 20$ & 24.5 & 60 & 9.8 & 6,8 \\
\hline 28/nov/80 & $12: 310$ & 25,0 & 65 & 11 & 7.3 \\
\hline $13 / d \theta z / 88$ & $12: 10$ & 25.5 & 60 & 25 & 6.8 \\
\hline 16/jan/a9 & 11.45 & 28.0 & so & 11 & 6.9 \\
\hline 23/føv/80 & $14: 05$ & 24.0 & 50) & 10 & 7.17 \\
\hline $28 /$ mart 89 & 12:10 & 23.5 & 30 & 5,5 & 6.7 \\
\hline iolabrt89 & $12: 35$ & 24,0 & 50 & 7.7 & 6.7 \\
\hline 3/gut/89 & (3:40) & 20.0 & so & 6.5 & 6.6 \\
\hline 16finovif89 & $11: 45$ & 24,0 & 120 & 20 & \\
\hline $4 / d e z / 89$ & $12: 00$ & 23,0 & 50 & 11 & $\hat{6} \hat{b}$ \\
\hline $2 / \mathrm{fan} / 90$ & $13: 40$ & 24,5 & 160 & 150 & 6.8 \\
\hline $5 / f \theta v / 90$ & 11.55 & 26.0 & 100 & 10 & 6.6 \\
\hline 12/mar/90 & $12: 00$ & 27,5 & 40 & 15 & 6.6 \\
\hline 1/jur/90 & $12: 10$ & 20,0 & $: 00$ & 15 & 7.1 \\
\hline 2/jul/90 & $11: 56$ & 18,0 & 10 & 15 & 6.8 \\
\hline 29/ago/90 & $10: 50$ & 190 & 140 & 25 & 6.8 \\
\hline $10 / \mathrm{sev} / 90$ & $11: 15$ & 20.5 & 60 & 25 & 6.6 \\
\hline 10/ourgo & 12.55 & 26,5 & 50 & 10 & 7.9 \\
\hline 21/now/90 & $12: 10$ & 25.0 & 80 & 18 & 0.7 \\
\hline $3 / d \in z / 90$ & 1445 & 25.0 & 40 & 30 & 6.6 \\
\hline 3/jan/9i & $16: 10$ & 28.0 & 80 & 11 & 7.1 \\
\hline 1/4mar/91 & $12: 50$ & 24.5 & 250 & 65 & 6.2 \\
\hline 1/abrr/91 & $1 \pm .50$ & 26,0 & 80 & 35 & 0.5 \\
\hline $9 /$ mai/91 & $13: 15$ & 24.5 & so & 13 & 6.5 \\
\hline 6/un/91 & $11: 05$ & 18.5 & 40 & 9.5 & 5.5 \\
\hline 1/j/jw//91 & $10: 20$ & 17.5 & 70 & 9 & 5.8 \\
\hline 27/ago/91 & $10: 06$ & 190 & 79 & 12. & 7.4 \\
\hline 10/sov91 & $10: 10$ & 17.0 & 100 & 13 & 5.8 \\
\hline 3/out 91 & $14: 25$ & 26.0 & 90 & 17 & 5.1 \\
\hline 4/nov/91 & $14: 00$ & 21.5 & 80 & 16 & 6.7 \\
\hline 10/dez/91 & $12: 05$ & 24.5 & 300 & 56 & 5.6 \\
\hline $9 /$ jan 992 & 10.05 & 23.5 & 500 & 150 & 3.6 \\
\hline $12 f \mathrm{fev} / 92$ & $10: 40$ & 24.0 & 135 & 30 & 6.5 \\
\hline $9 /$ mari92 & $10: 20$ & 24.0 & 50 & 10 & 6.5 \\
\hline 1/abri92 & $12 \% 0$ & 25.5 & 70 & 9.5 & 5.6 \\
\hline t/mai/92 & $12: 20$ & 22.5 & 50 & 7.5 & 7.1 \\
\hline $2 / \mathrm{j}$, $\mathrm{N} / 92$ & 99:25 & 19.0 & 50 & 12 & 7.0 \\
\hline $22 / \mathrm{jw} / / 92$ & $09: 30$ & 16.5 & 100 & 13 & 6.8 \\
\hline 18/ago/92 & $10: 00$ & 18.0 & 160 & 20 & 7.2 \\
\hline 14/set/92. & 10:05 & 19.5 & 80 & 15 & 7.0 \\
\hline 13/outi9? & $10: 50$ & 22.5 & 80 & 15 & 7.3 \\
\hline 10/novi92 & $22: 20$ & 23.0 & 100 & 22 & 66 \\
\hline $9 /$ dez $/ 92$ & $10: 40$ & & 70 & 8.5 & 6.5 \\
\hline 6rjan/93 & 10:45 & 22.5 & 400 & 110 & 6.6 \\
\hline $10 / / \mathrm{ev} / 93$ & $09: 30$ & 33.5 & 100 & 25 & 6.7 \\
\hline $21 /$ mar $/ 93$ & $12: 20$ & 25.0 & 10 & 7.5 & 6.7 \\
\hline S/abr/93 & $10: 20$ & 23,0 & 70 & 15 & 6.6 \\
\hline 11/mai/93 & 10:05 & 19,0 & 60 & 9.6 & 7.0 \\
\hline
\end{tabular}




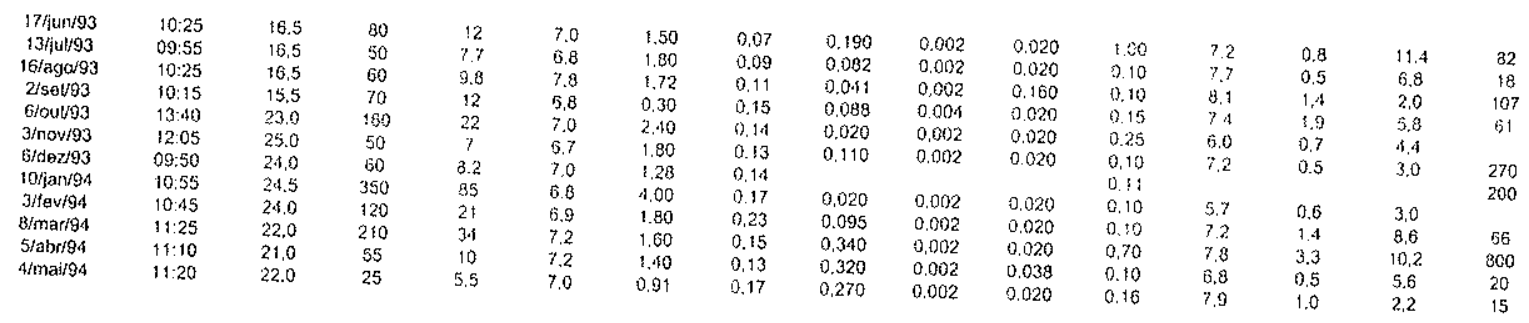

\begin{tabular}{|c|c|c|c|c|c|c|c|c|c|c|c|c|c|c|c|}
\hline Estalistica Descriliva & Gide rosultai & 103 & 102 & 103 & 102 & 104 & 103 & 97 & 48 & 91 & 18 & 99 & 90 & .16 & 60 \\
\hline \multirow{4}{*}{ Paramotrica } & Medtia & 22,1 & 78.3 & 21.9 & 6.8 & 2.13 & 0,14 & 0.102 & 0.003 & 0.055 & 0.23 & 6.9 & 1.1 & 18,5 & 848,7 \\
\hline & $\begin{array}{l}\text { Med. Geomil } \\
\text { Moda }\end{array}$ & 22,2 & 52,2 & 14.6 & 6.6 & 1.80 & 0,13 & 0,044 & 0.002 & 0.019 & 0,17 & 6,9 & 0,8 & 8,8 & 111.3 \\
\hline & $\left\{\begin{array}{l}\text { Moda } \\
\text { Desvio padrax }\end{array}\right.$ & $\begin{array}{l}23.0 \\
32\end{array}$ & $\begin{array}{l}100,0 \\
79,9\end{array}$ & $\begin{array}{l}10.0 \\
276\end{array}$ & 6,6 & 1,80 & 0.13 & 0,001 & 0.002 & 0.020 & 0,10 & 7.5 & 0.5 & 2.0 & 20.0 \\
\hline & $\begin{array}{l}\text { Uesvio padra } \\
\text { Coaf. Variace }\end{array}$ & $\begin{array}{l}3,2 \\
0,1 \\
\end{array}$ & $\begin{array}{r}13.9 \\
1.0 \\
\end{array}$ & $\begin{array}{r}27.6 \\
1.3 \\
\end{array}$ & $\begin{array}{l}0.3 \\
0.1\end{array}$ & $\begin{array}{l}1.41 \\
0.7\end{array}$ & $\begin{array}{l}0,05 \\
0.4\end{array}$ & $\begin{array}{c}0,117 \\
1,1\end{array}$ & $\begin{array}{c}0.003 \\
1.2\end{array}$ & $\begin{array}{c}0.109 \\
2,0\end{array}$ & $\begin{array}{l}0.25 \\
1.1\end{array}$ & 0.7 & 0,9 & 32,5 & $\begin{array}{c}3196.5 \\
3.8\end{array}$ \\
\hline \multirow{4}{*}{ Nào-Paramótrica } & Minimo & 15.0 & 2.0 & 2.0 & 5.9 & 0.10 & 0,05 & 0.001 & $\frac{1.2}{0.001}$ & $\frac{2,0}{0.001}$ & 0,05 & $\frac{0,1}{5.2}$ & $\frac{0.9}{0.1}$ & $\frac{1,8}{0,8}$ & $\frac{3.8}{10.0}$ \\
\hline & Quartil 1 & 20.0 & 90.0 & 9.0 & 6.4 & 1.30 & 0.11 & 0,020 & 0,002 & 0.010 & 0.10 & 0.5 & 0.5 & $\begin{array}{l}.0 \\
5.3\end{array}$ & 32,0 \\
\hline & $\begin{array}{l}\text { Mediana } \\
\text { Qutartil } 3\end{array}$ & 23.0 & 60,0 & 12,0 & 6,6 & 1.71 & 0,13 & 0.067 & 0.002 & 0.020 & 0.10 & 7.0 & 0,7 & 6.9 & 80.0 \\
\hline & Máximo & $\begin{array}{l}21,5 \\
31,0 \\
\end{array}$ & $\begin{array}{r}100,0 \\
5000\end{array}$ & $\begin{array}{l}21.5 \\
150,0\end{array}$ & $\begin{array}{l}6.8 \\
7.8\end{array}$ & $\begin{array}{l}2.40 \\
8,60\end{array}$ & $\begin{array}{l}0.16 \\
0.32\end{array}$ & $\begin{array}{l}0,400 \\
0,610\end{array}$ & 0,002 & 0,058 & $\begin{array}{l}0.25 \\
130\end{array}$ & 7.4 & 1.4 & 13.9 & 262.5 \\
\hline
\end{tabular}


ANEXO 2 - BACIA DO RIBEIRÃO SERRA AZUL

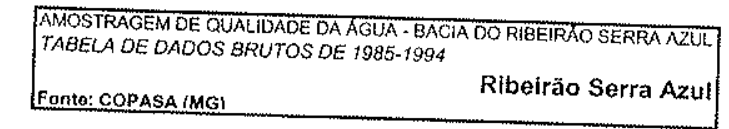

\begin{tabular}{|c|c|c|c|c|c|}
\hline Data & Ftora & $\begin{array}{l}\text { Tompera } \\
\text { tura }\left({ }^{\circ} \mathrm{C}\right)\end{array}$ & $\begin{array}{l}\text { Cor } \\
\text { (UPT) }\end{array}$ & $\begin{array}{c}\text { Turbldoz } \\
\text { (NTU) }\end{array}$ & $\mathrm{OH}$ \\
\hline $\begin{array}{l}9 j a r / 85 \\
27 / f_{\theta v} / 85\end{array}$ & $\begin{array}{l}74: 30 \\
12: 05\end{array}$ & 21,5 & 250 & $\begin{array}{l}170 \\
46\end{array}$ & 6.7 \\
\hline $4 / \mathrm{mar} / 85$ & $12: 00$ & $\begin{array}{l}23.0 \\
23.0\end{array}$ & $\begin{array}{l}200 \\
200\end{array}$ & $\begin{array}{l}46 \\
58\end{array}$ & $\begin{array}{l}6.9 \\
6.5\end{array}$ \\
\hline 1/abrid85 & $11: 10$ & 22,0 & 150 & 65 & 6.9 \\
\hline 21/mal/85 & $12: 40$ & 10.0 & 10 & 17 & 6.8 \\
\hline 17/fun/85 & $11: 40$ & 15.2 & 35 & 12 & 6,8 \\
\hline 22 jutulBs & $14: 15$ & 15,0 & 20 & 8 & 5,9 \\
\hline 27lago/05 & $14: 10$ & 21,0 & 30 & 8,3 & 7.2 \\
\hline 17/58v85 & $11: 45$ & 18.5 & 20 & 9 & 6.9 \\
\hline 28/ouv85 & $14: 20$ & 23,0 & 50 & 12 & 6,8 \\
\hline $19 /$ nov/85 & $13: 45$ & 23.5 & $\begin{array}{l}60 \\
28\end{array}$ & 10 & 7.1 \\
\hline $16 / d e z / B 5$ & 1200 & 22.0 & 28 & $\begin{array}{l}18 \\
84\end{array}$ & 7,0 \\
\hline 15fjan/86 & $\begin{array}{l}15: 35 \\
14: 65\end{array}$ & 210 & 200 & $\begin{array}{l}84 \\
43\end{array}$ & 6.6 \\
\hline 17/fevi86 & $14: 65$ & 22,0 & $\begin{array}{l}60 \\
45\end{array}$ & $\begin{array}{l}43 \\
22\end{array}$ & 6.5 \\
\hline $17 /$ marli86 6 & $\begin{array}{l}14: 00 \\
15: 00\end{array}$ & 24,0 & 45 & 22 & 6,8 \\
\hline 11/abr/86 & $\begin{array}{l}15: 00 \\
13.55\end{array}$ & 23.0 & 30 & 20 & 0.9 \\
\hline $12 / m a i / 86$ & $13: 55$ & 21.5 & 40 & 15 & 6.7 \\
\hline $17 \mathrm{j}$ untag & $14: 15$ & 17.5 & 30 & 7,5 & 6.6 \\
\hline $15 / j u t / 86$ & $14: 33$ & 15.5 & 10 & 8 & 7,1 \\
\hline $14 /$ ago/86 & $12: 55$ & 19.0 & 30 & 10 & 7.1 \\
\hline $15 / \mathrm{set} / 86$ & $14: 20$ & 19.5 & 30 & 8 & 7,1 \\
\hline 13/out/86 & 14:00 & 22.0 & 40 & 8.2 & 6.8 \\
\hline 201novi86 & $11: 30$ & 22,0 & 50 & 15 & 6,7 \\
\hline 16/flez/86 & $12: 00$ & 23.5 & 400 & 330 & 6.6 \\
\hline $1.3 / j a n / 87$ & $18: 10$ & 28,0 & 90 & 49 & 6,7 \\
\hline 9Hev/87 & $15: 00$ & 25.5 & 75 & 47 & 6,6 \\
\hline 16/Rev/87 & $11: 10$ & 21,0 & 500 & 85 & 6.0 \\
\hline 16/mar/87 & $10: 35$ & 21.5 & 700 & 625 & 6.1 \\
\hline 9/abr/a7 & $10: 10$ & 22.5 & 50 & 21 & 6,3 \\
\hline $11 /$ mai $/ 87$ & $09: 50$ & 20.0 & & 12 & 6.8 \\
\hline 8//un/87 & $10: 40$ & 19.5 & 30 & 9.4 & 6.7 \\
\hline 1Afjul/87 & $10: 00$ & 17.5 & 50 & 10 & 6.9 \\
\hline 11/ago/87 & $11: 30$ & 17,0 & 40 & 3 & 6.9 \\
\hline I-1/sot87 & $11: 20$ & 21.0 & 60 & 9 & 7.0 \\
\hline 2010ut87 & $10: 30$ & 23.5 & 60 & 11 & 7.2 \\
\hline 17irov/87 & $11 \% 0$ & 21,0 & & & \\
\hline $13 / \mathrm{J}$ an/8g & 10:15 & 22.0 & 100 & 96 & 6.7 \\
\hline 19 f)ant8 8 & $10: 30$ & 24,5 & 100 & 31 & 6,8 \\
\hline 20fjan/BB & $10: 40$ & 23.0 & 65 & 22 & 7,2 \\
\hline $18 / f e v / 83$ & $13: 25$ & $2 n, 0$ & & & \\
\hline 14/mari/88 & $14: 32$ & 24,0 & 30 & 12 & 6.4 \\
\hline 25fabr/88 & 11:00 & 13,0 & 200 & 12 & 6.9 \\
\hline 17/mai/BB & $11: 15$ & 20.0 & 50 & 6.7 & 0,8 \\
\hline 20 funv/88 & $11: 25$ & $\$ 5.0$ & 50 & 7.3 & 7,2 \\
\hline 18/jw/88 & 10.45 & 16.0 & 60 & 10 & 7.3 \\
\hline 16rago/as & 11:05 & 12.5 & 40 & 7.3 & 6,8 \\
\hline $19 / \mathrm{sut} 88$ & $11: 00$ & 20,5 & 50 & 6,8 & 7.3 \\
\hline $28 /$ hov/8B & 1130 & 22.0 & 45 & 10 & 7.5 \\
\hline IJ/dez/88 & $10: 55$ & 23.0 & 70 & 25 & 6.8 \\
\hline $16 / j a n / 89$ & $13: 35$ & 26.0 & 60 & 17 & 7.4 \\
\hline 23/tev/89 & $15: 10$ & 240 & 30 & 15 & 6.7 \\
\hline $2 B /$ marris9 & $10: 45$ & 23,5 & 80 & 17 & 7.3 \\
\hline $10 / a b d / 89$ & $11: 18$ & 230 & 50 & 10 & 7.2 \\
\hline tomai/89 & 11:30 & 20.0 & 50 & 9,7 & 7.3 \\
\hline Sfijun/89 & $\begin{array}{l}11: 00 \\
1235\end{array}$ & 20.0 & 30 & 7.6 & 7.4 \\
\hline $\begin{array}{l}\text { 3/ill/89 } \\
\text { thago/39 }\end{array}$ & $\begin{array}{l}12: 35 \\
10: 30\end{array}$ & $\begin{array}{r}17.9 \\
170\end{array}$ & 50 & $\begin{array}{l}12 \\
15\end{array}$ & 7,2 \\
\hline & $\begin{array}{l}10: 30 \\
10: 15\end{array}$ & $\begin{array}{l}17,0 \\
17.0\end{array}$ & $\begin{array}{l}60 \\
50\end{array}$ & $\begin{array}{r}15 \\
0.5\end{array}$ & 7,4 \\
\hline $\begin{array}{l}\text { 4/5et89 } \\
2 \text { fouv89 }\end{array}$ & $12: 50$ & $\begin{array}{l}17.0 \\
18.0\end{array}$ & $\begin{array}{l}50 \\
60\end{array}$ & $\begin{array}{l}3.5 \\
10\end{array}$ & $\begin{array}{l}7,3 \\
7.5\end{array}$ \\
\hline $\begin{array}{c}22 \text { ouv89 } \\
16 \text { frov/89 }\end{array}$ & $10: 40$ & 21.0 & 10 & 17 & \\
\hline f/lez/89 & $10: 50$ & 21.0 & 30 & 3,5 & 7.3 \\
\hline $2 \operatorname{jan} / 90$ & $12: 30$ & 22.0 & 210 & 122 & 5,1 \\
\hline Sflev/9o & 1100 & 22.10 & 100 & 10 & 7.2 \\
\hline $12 / m a r f 90$ & 1100 & 23.5 & 40 & 12 & 7.1 \\
\hline $2 / a b r / 90$ & $10: 20$ & 23.5 & 50 & 8,5 & 7,2 \\
\hline $4 / \mathrm{j}$ thr/90 & $11: 00$ & 175 & 50 & 5.5 & 7,3 \\
\hline $2 / \mathrm{fuH} / 90$ & $10: 28$ & 16.5 & 10 & 6 & 7.1 \\
\hline 29fagorgo & $09: 40$ & 17.5 & 70 & 15 & 7.4 \\
\hline $10 /$ set/90 & $10: 10$ & 19.5 & 60 & 7.5 & 7,3 \\
\hline $10 f 0 u t 90$ & 10.55 & 22.5 & 60 & 7 & 7.4 \\
\hline 21/rov/90 & $11: 00$ & 23.5 & 90 & 19 & 7.1 \\
\hline $3 / 6 \mathrm{e} / 90$ & $13: 55$ & 22.5 & 70 & 16 & 7.2 \\
\hline $3 / \mathrm{a} a \mathrm{g1}$ & 15:15 & 24.5 & 00 & 8.7 & 7.5 \\
\hline atmar/91 & $13: 50$ & 240 & 350 & 95 & 0.1 \\
\hline $1 /$ abro1 & $11: 00$ & 24.5 & 100 & 42 & 7.1 \\
\hline $9 / m a i / 91$ & 11:35 & 22.5 & 60 & 12 & 7.1 \\
\hline $8 / j u n / 91$ & $10: 15$ & 18.0 & 50 & B.5 & 7.3 \\
\hline 1/ju/g1 & $11: 15$ & 16,5 & 50 & 8 & 7,2 \\
\hline 27/ago/91 & 1100 & 18.0 & 10 & 0.4 & 7.6 \\
\hline 10/sel/91 & 11:25 & 17.0 & 60 & 9 & 7.4 \\
\hline 3/oul91 & $15: 15$ & 24.0 & 650 & 180 & 6.9 \\
\hline thov/91 & $15: 40$ & 23.5 & 90 & 22 & 7.2 \\
\hline 10/dez/91 & $13: 00$ & 23.5 & 250 & 40 & 7,6 \\
\hline $9 / \mathrm{jan} / 92$ & $10: 55$ & 23.0 & 200 & 30 & 7.3 \\
\hline $12 / f \mathrm{fv} / 92$ & $11: 35$ & 22.5 & 100 & 28 & 7.0 \\
\hline 9htmar/92 & $11 \cdot 10$ & 26,0 & 140 & 27 & 6,9 \\
\hline 1/abrig2 & $13: 25$ & 23.0 & 100 & 17 & 7.0 \\
\hline t/mai/92 & $t 4: 10$ & 21.5 & 80 & 13 & 7.5 \\
\hline 2/fun/92 & $10: 10$ & 18.5 & 50 & 7.3 & 7.2 \\
\hline 22/fitu/92 & $10: 10$ & 16.0 & 60 & 8.5 & 7,2 \\
\hline : 8/aggo/92 & $11: 35$ & 180 & 40 & 6 & 74 \\
\hline $14 /$ set/92 & $\begin{array}{l}11: 00 \\
13: 35\end{array}$ & $\begin{array}{l}18.5 \\
22.0\end{array}$ & 60 & 9.5 & 7.5 \\
\hline $\begin{array}{l}\text { 10/tovi92 } \\
9 / d \text { def } 92\end{array}$ & $\begin{array}{l}13: 35 \\
11: 40\end{array}$ & 22.0 & 250 & 80 & 6.9 \\
\hline & & & & 33 & 6.7 \\
\hline
\end{tabular}




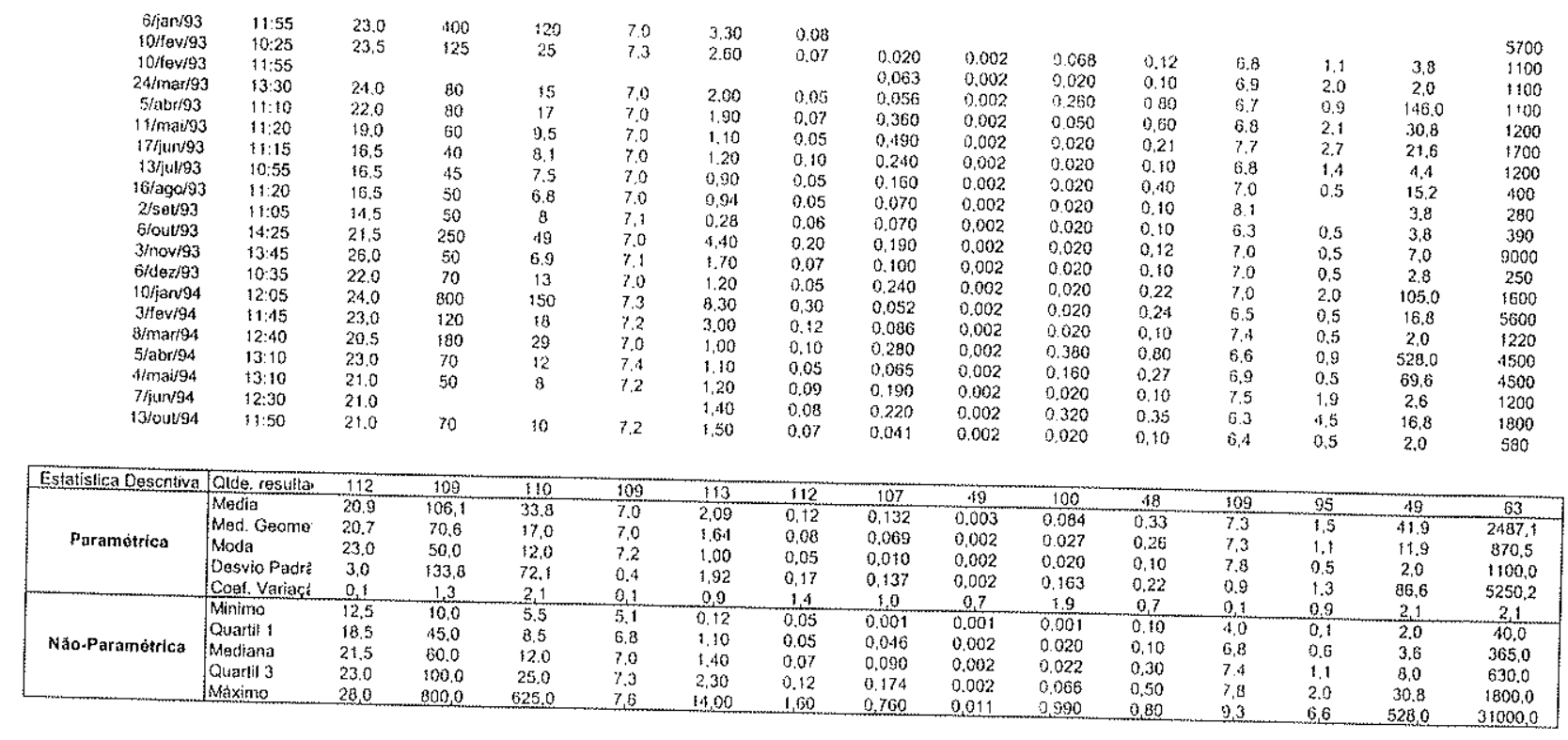


ANEXO 2 - BACIA DO RIBEIRÃO SERRA AZUL

AMOSTRAGEM DE QUALIDADE DA KGUA + BACIA DO RIBEIRAO SERRA AZU
TABELLA DE DADOS BRUTOS DE 1985.1994 Córrego do Diogo
Fonta: COPASA MMG

\begin{tabular}{|c|c|c|c|c|c|c|c|}
\hline Data & Hora & $\begin{array}{l}\text { Tompera- } \\
\text { tura }\left({ }^{\circ} \mathrm{C}\right)\end{array}$ & $\operatorname{Cot}(\mathrm{UPT})$ & $\begin{array}{c}\text { Turbldoz } \\
\text { (NTU) }\end{array}$ & $\mathrm{pH}$ & $\begin{array}{c}\begin{array}{c}F_{0} \text { total } \\
\text { (mg/ Fo })\end{array} \\
\text { (a) }\end{array}$ & $\begin{array}{l}\text { Mn tota } \\
\text { img/l } M n\end{array}$ \\
\hline 7 jantros & $12: 25$ & 23.0 & 100 & 43 & 6.5 & 1.20 & 0.20 \\
\hline $\begin{array}{l}25 / / 8 v / 85 \\
5 / \text { marr85 }\end{array}$ & $12: 05$ & 24,5 & 100 & 30 & 6,6 & 1,50 & 0.18 \\
\hline $\begin{array}{l}5 / \text { mar } 85 \\
\text { 2/abr/85 }\end{array}$ & $12: 15$ & 23.0 & 250 & 65 & 6.4 & 2.60 & 0,14 \\
\hline $\begin{array}{c}\text { 2/abri/85 } \\
\text { 20/mai/85 }\end{array}$ & $11: 40$ & 22,0 & 150 & 45 & 6.6 & 1,90 & 0,14 \\
\hline $18 /$ un/85 & $\begin{array}{l}12: 30 \\
11: 45\end{array}$ & 20.0 & 10 & 8 & 6.4 & 1,20 & 0.15 \\
\hline $23 \mathrm{fin} / \mathrm{H} / 85$ & $\begin{array}{l}11: 45 \\
12: 40\end{array}$ & & 25 & 2.3 & 5.1 & 1.30 & 0,12 \\
\hline 26/ago/85 & 1.120 & $\begin{array}{l}17.0 \\
99.5\end{array}$ & $\begin{array}{l}10 \\
15\end{array}$ & $\begin{array}{c}5 \\
15\end{array}$ & 6.6 & 0,73 & 0,10 \\
\hline f6/sot/85 & $12: 45$ & 19.0 & $\begin{array}{l}15 \\
20\end{array}$ & $\begin{array}{l}15 \\
8\end{array}$ & 6,9 & 0.77 & 0.35 \\
\hline $28 /$ out/85 & $15: 35$ & 23.5 & 30 & $\begin{array}{c}8 \\
10\end{array}$ & 6.4 & 0.77 & 0,07 \\
\hline $19 / n o v / 85$ & 14.35 & 24,0 & to & $\begin{array}{l}10 \\
8\end{array}$ & 6.8 & 0.78 & 0.05 \\
\hline $16 /$ dez/85 & 11.55 & 23,0 & 33 & $\begin{array}{c}8 \\
10\end{array}$ & 6.5 & 0.85 & 0.06 \\
\hline $15 / j a n / 86$ & $16: 10$ & 21.0 & 100 & 62 & 6.7 & 1.50 & 0.09 \\
\hline $17 / \mathrm{fev} / 36$ & $15: 30$ & 23,0 & 250 & 140 & $\begin{array}{l}6.2 \\
6.1\end{array}$ & 5.00 & 0,05 \\
\hline $17 /$ mar/86 & $14: 55$ & 24.0 & 30 & 15 & $\begin{array}{l}6.1 \\
6.5\end{array}$ & 11,00 & 0,09 \\
\hline $14 / a b r / B 6$ & $15: 10$ & 23.0 & 10 & 11 & 6.5 & 1.20 & 0.15 \\
\hline $12 /$ mair/86 & $14: 30$ & 22.0 & 60 & 60 & 6.6 & 1,80 & 0,23 \\
\hline $17 /$ fund 86 & 1.405 & 13.0 & 20 & 11 & 5.1 & 2,90 & 0.09 \\
\hline $15 / \mathrm{ju} / / 86$ & $15: 08$ & 16,0 & 5 & 11 & 6,6 & 0,72 & 0,07 \\
\hline 1 H/ago/86 & $13: 35$ & 19.0 & 15 & $\begin{array}{l}13 \\
5\end{array}$ & 6.6 & 0.55 & 0.06 \\
\hline $15 /$ saves & $14: 50$ & 20.5 & 15 & 10 & 6.8 & 0.65 & 0.08 \\
\hline 13/ouv86 & $15: 05$ & 22.0 & 25 & 7.5 & 6.7 & 0.63 & 0.05 \\
\hline 20/nov/BE & $12: 10$ & 20.5 & 20 & 8 & $\begin{array}{l}6.5 \\
6.5\end{array}$ & 0,91 & 0.05 \\
\hline $16 /$ dez/8 6 & $13: 20$ & 26,0 & 150 & 66 & $\begin{array}{l}6.5 \\
6.4\end{array}$ & 0,72 & 0,05 \\
\hline 13/fan/87 & $11: 42$ & 29.0 & 70 & 17 & $\begin{array}{l}6.4 \\
6.6\end{array}$ & 1.30 & 0.09 \\
\hline 16/fovi87 & $11: 55$ & 23.0 & BO & 10 & $\begin{array}{l}6.6 \\
6.2\end{array}$ & 1,30 & 0.14 \\
\hline $16 / \mathrm{mar} / 87$ & $11: 10$ & 22,5 & 70 & 20 & $\begin{array}{l}6.2 \\
6.6\end{array}$ & 1.80 & 0.14 \\
\hline 9/abrrg7 & $10: 50$ & 22.0 & 30 & 10 & $\begin{array}{l}6,6 \\
6,1\end{array}$ & 1.70 & 0.37 \\
\hline 11/mai/8? & $10: 25$ & 20.0 & & 6.6 & $\begin{array}{l}6.1 \\
6.5\end{array}$ & 1.40 & 0,15 \\
\hline 8/jun/97 & $: 1: 15$ & 19.5 & 20 & 6.1 & $\begin{array}{l}0,3 \\
6,6\end{array}$ & 1.10 & 0.15 \\
\hline $14 / / \mathrm{j} / / 87$ & $10: 30$ & 17.0 & 40 & 16 & $\begin{array}{l}6.6 \\
6.5\end{array}$ & 0.96 & 0.09 \\
\hline 11/ago/87 & $12: 20$ & 18.0 & 90 & 6 & & 0.46 & 0.05 \\
\hline $14 / \mathrm{set} / 87$ & $12: 10$ & 20,0 & 30 & 7.4 & 6.5 & 0.41 & 0.06 \\
\hline 20/0ut/87 & $11: 05$ & 23.5 & 50 & 8 & 6.6 & 0.59 & 0.10 \\
\hline $17 / 110 v / 87$ & $12: 20$ & 21.0 & & & 7.0 & 1,80 & \\
\hline $13 / /$ an $/ 88$ & $10: 50$ & 22.5 & 50 & 56 & 6.5 & 1.40 & 0.10 \\
\hline 18/jan/g8 & 10.55 & 23.0 & 70 & 28 & $\begin{array}{l}0.3 \\
5.7\end{array}$ & 1,10 & 0.13 \\
\hline $26 /$ tanf 88 & 1:10 & 23.0 & 60 & 18 & 6.8 & 2.80 & 0.10 \\
\hline Igffevige & $12: 35$ & 23.5 & 120 & 30 & 6.4 & 1.90 & 0,27 \\
\hline 1.1/mar/88 & 13.49 & 23.0 & 40 & 9.4 & 5.5 & 1,70 & 0.15 \\
\hline $25 / a b r / 8 B$ & $11: 55$ & 21.0 & 180 & 15 & 6.5 & 2.00 & 0.23 \\
\hline :7/mair88 & $11: 55$ & 20.0 & 50 & 5.6 & 6.7 & $\begin{array}{l}0,90 \\
1.40\end{array}$ & 0.16 \\
\hline 20/fнr:/B8 & $12: 00$ & 16.0 & 50 & 5.5 & 6,9 & $\begin{array}{l}1.40 \\
0.75\end{array}$ & 0.20 \\
\hline $10 / \mathrm{ful} / 88$ & $11: 15$ & 660 & so & b) & 6,6 & $\begin{array}{l}0,75 \\
0,65\end{array}$ & 0.13 \\
\hline 16/ago/88 & $11: 35$ & 14.0 & 20 & 5.9 & 6.5 & $\begin{array}{l}0.65 \\
0.50\end{array}$ & 0.14 \\
\hline $19 /$ sover & $11: 40$ & 20.5 & 10 & 5.8 & 7.1 & 0.50 & 0.13 \\
\hline $2 B /$ T:OVIBB & 1200 & 22,0 & 30 & 7 & 7.1 & 0.68 & 0.05 \\
\hline $12 / \mathrm{dez} / 88$ & $11: 35$ & 23.0 & 50 & 15 & 6.7 & 0,88 & 0.07 \\
\hline 16:j|an:89 & $14: 15$ & 25.5 & 30 & 3.5 & 70 & $\begin{array}{l}1.20 \\
0.86\end{array}$ & 0.08 \\
\hline $23 / \mathrm{ev} / 89$ & $14: 55$ & 22.5 & 100 & 17 & 6.9 & $\begin{array}{l}0.86 \\
200\end{array}$ & 0.04 \\
\hline 28/mar/89 & $11: 30$ & 23,5 & 50 & 10 & 7.4 & 2,00 & 0.15 \\
\hline Tofabrisg & $11: 58$ & 23.5 & 50 & 16 & 73 & 1,30 & 0.74 \\
\hline $10 / \mathrm{mal} / 89$ & $12: 10$ & 19,0 & & & & 0,70 & 0,10 \\
\hline 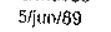 & $11: 30$ & 20.5 & 30 & 7.5 & 5.8 & 0.80 & 0,10 \\
\hline $3 \mathrm{j}$ ju/89 & $13: 10$ & 17.5 & so & 6,1 & 6.8 & 1,00 & 0.00 \\
\hline 1/ago/89 & $1: 05$ & 18,5 & 40 & 7,7 & 6.7 & 0.70 & 0.08 \\
\hline$\pi /$ sev89 & $10: 50$ & 19.0 & 30 & 6,4 & 7.0 & 0.82 & 0.05 \\
\hline 2/orvBg & $13: 35$ & 98.5 & 40 & 7 & 7.1 & 1,06 & 0.05 \\
\hline 16/novis9 & $1: 10$ & 21.5 & 60 & 9 & 7.0 & 0.82 & 0.07 \\
\hline Hidez/39 & $11: 30$ & 21.0 & so & 0.5 & 6.9 & 1.00 & 0,05 \\
\hline 2/jan/90 & $13: 05$ & 22.0 & 90 & 57 & $\begin{array}{l}6.9 \\
5.6\end{array}$ & 0.97 & 0.10 \\
\hline $5 /$ / & 1125 & 22.0 & 100 & 6 & $\begin{array}{l}5.6 \\
0.9\end{array}$ & 1.82 & 0.09 \\
\hline $12 / \mathrm{mar} / 90$ & $11: 35$ & 24.0 & 20 & 9.5 & 0.9 & 1.53 & 0.03 \\
\hline 2/abr/90 & $11: 00$ & 22.5 & 30 & $\begin{array}{l}9.5 \\
4.6\end{array}$ & 6,9 & 1,40 & 0.08 \\
\hline 4/jun/90 & $11: 40$ & 18.0 & 30 & $\begin{array}{l}4,6 \\
4.5\end{array}$ & 7.0 & 0.86 & 0.07 \\
\hline $2 \mathrm{fj}_{\mathrm{w}} \mathrm{s} / 90$ & $11: 25$ & 18,5 & 30 & $\begin{array}{c}4.3 \\
5\end{array}$ & 7.1 & 0.83 & 0.05 \\
\hline $29 / \mathrm{ago} / 90$ & $10 \cdot 20$ & 17.5 & 50 & $\begin{array}{c}5 \\
6.5\end{array}$ & 7.0 & 0.88 & 0.05 \\
\hline 10/sev90 & 10.45 & 20.5 & 40 & $\begin{array}{c}6.5 \\
6\end{array}$ & 6.9 & 0.83 & 0.05 \\
\hline 10\%out 90 & $12: 15$ & 23.5 & 50 & $\begin{array}{l}6 \\
7.5\end{array}$ & 5.9 & 1,00 & 0.015 \\
\hline 21/row/90 & 1105 & 23,0 & 50 & 8,9 & 7.0 & 1.00 & 0.07 \\
\hline 3/dez/90 & $1.4: 15$ & 24.5 & 50 & $\begin{array}{l}8,9 \\
7.5\end{array}$ & 6.8 & 1.45 & 0.11 \\
\hline $3 f \mathrm{fan} / 91$ & $15: 50$ & 25,0 & 40 & 5.8 & 6,9 & 0.95 & 0.05 \\
\hline $4 / m a r / 91$ & $13: 10$ & 23.5 & 90 & 20 & 7.2 & 0.94 & 0.08 \\
\hline 1/abr/91 & $11: 25$ & 25.5 & 70 & 19 & 6.5 & 1.00 & 0.18 \\
\hline g/mai/gt & $12: 40$ & 22.0 & 40 & 6.5 & 7.1 & 2.00 & 0.09 \\
\hline 6rtitur/91 & $10: 50$ & 17.5 & 30 & 5 & 6.7 & 1.00 & 0.09 \\
\hline $1 / / j w / 91$ & 10.50 & 16.5 & 40 & 5 & 6.8 & 0,60 & 0,06 \\
\hline 27/ago/91 & $10: 30$ & 18.0 & 20 & 4.6 & 7.0 & 0.70 & 0.08 \\
\hline 10/sev/91 & 10.50 & 16.0 & 70 & 13 & 7,2 & 0.60 & 0.06 \\
\hline 3/ouvg1 & $: 1.50$ & 23.5 & 80 & 23 & 7.0 & 0.92 & 0.09 \\
\hline 4/กovig1 & $15: 00$ & 22.5 & 70 & is & $\begin{array}{l}0.6 \\
6.5\end{array}$ & 1.40 & 0.07 \\
\hline 10/duz $/ 91$ & $12: 35$ & 23.5 & 160 & 32 & $\begin{array}{l}8.5 \\
7.3\end{array}$ & 0.93 & 0.05 \\
\hline $9 / \operatorname{an} / 92$ & $10: 30$ & 24,0 & 100 & 25 & $\begin{array}{l}7.1 \\
7.0\end{array}$ & 5,40 & 0.00 \\
\hline $12 /$ fev/92 & $11: 05$ & 22,5 & 80 & 17 & $\begin{array}{l}7.0 \\
6.9\end{array}$ & 3,20 & 0,07 \\
\hline $1 / a b s / 92$ & $13: 05$ & 23.5 & 60 & 9.4 & $\begin{array}{l}6.9 \\
0.6\end{array}$ & 1.80 & 0.08 \\
\hline $4 / \mathrm{ma} / 292$ & $13: 10$ & 21.5 & 50 & 9.7 & $\begin{array}{l}0.6 \\
7.2\end{array}$ & 1,30 & 0.10 \\
\hline 2/jun/92. & $00: 50$ & 19.5 & 30 & 3 & $\begin{array}{l}7.2 \\
6.9\end{array}$ & 5.20 & 0.16 \\
\hline $22 / \mathrm{ju} / 92$ & $09: 50$ & 16.5 & 30 & 4.5 & & 0.90 & 0.08 \\
\hline 18/agoig2 & $11: 00$ & 18.5 & 30 & 4,8 & 7.0 & 0,50 & 0.07 \\
\hline 14/sav/92. & $10: 40$ & 19.0 & 40 & 7 & 73 & $\begin{array}{l}0,80 \\
0,83\end{array}$ & 0.05 \\
\hline & & & & & & 0.83 & 0.05 \\
\hline
\end{tabular}




\begin{tabular}{|c|c|c|c|c|c|c|c|c|c|c|c|c|c|c|c|}
\hline & & & & & & & & & & & & & & & \\
\hline 10/nov/92 & $13: 15$ & 23.5 & 150 & 35 & 8.6 & 0.76 & 0.08 & 0,080 & 0,002 & & 0.12 & 7.7 & 0,8 & 4,4 & 730 \\
\hline $9 /(1 e z / 92$ & $11: 05$ & & 70 & 12 & 6,7 & $\begin{array}{l}6,50 \\
1.30\end{array}$ & 0.11 & 0,060 & 0.002 & 0.027 & 0.17 & 7,6 & 2.9 & 16.4 & \\
\hline 6fjant93 & $11: 15$ & 23.0 & 200 & 50 & 6.8 & $\begin{array}{l}1.30 \\
1.90\end{array}$ & 0.09 & 0,082 & 0.002 & 0.020 & 0.13 & 7.7 & 0.5 & 4,2 & \\
\hline $10 /$ ov 193 & $09: 50$ & 22.5 & 60 & 12 & 6,9 & $\begin{array}{l}1.90 \\
2.30\end{array}$ & 0.08 & 0.110 & 0.002 & 0054 & 0.10 & 7.3 & $i .9$ & 2.8 & 3200 \\
\hline $2 \mathrm{~A} / \mathrm{mar} / 93$ & $12: 50$ & 24.0 & 40 & 9 & 6.9 & $\begin{array}{l}2.30 \\
1.10\end{array}$ & 0.08 & 0.220 & 0.002 & 0.084 & 0.15 & 6.4 & 0.5 & 60.4 & 320 \\
\hline 5/abr/93 & $10: 10$ & 23.0 & 40 & 0 & 6.9 & 1.40 & 0.05 & 0.092 & 0.002 & 0.310 & 0.26 & 7.3 & 0.5 & 8.2 & 710 \\
\hline $11 /$ mair93 & $10: 40$ & 23.0 & 10 & 6.5 & 7.0 & 100 & 0.26 & 0.170 & 0.002 & 9.020 & 0.70 & 10.0 & 3.3 & 11,8 & 310 \\
\hline 17hưnt93 & $10: 50$ & 15.5 & 30 & 5 & 6.9 & 0.60 & 0.12 & 0,160 & 0.002 & 0.020 & 0.20 & 7.3 & 0.5 & 1.8 & 250 \\
\hline 13/4w/93 & $10: 30$ & 15.5 & 25 & 4.5 & 7.0 & 0.60 & 0.05 & 0,043 & 0,002 & 0140 & 0,30 & 6.6 & 0.5 & 10.3 & 1700 \\
\hline 16/agoi93 & $10: 30$ & 16.5 & 40 & 5.5 & 6.9 & 0.79 & $\begin{array}{l}0.05 \\
.05\end{array}$ & 0.033 & 0.002 & 2.170 & 0.20 & 7.0 & 0.5 & 15,6 & 14000 \\
\hline $2 / 50493$ & $10: 40$ & 23.0 & 30 & 4.5 & 7.0 & 0,70 & $\begin{array}{l}0.05 \\
0.07\end{array}$ & 0,043 & 0,002 & 0.020 & 0,10 & 8,5 & 1,0 & 2.0 & 30 \\
\hline 6/ouv93 & $14: 10$ & 21.0 & 100 & 20 & 7.0 & 1.70 & 0.07 & $0,08 \cdot 1$ & 0,002 & 0.020 & 0.03 & 7.9 & 1.0 & 2.0 & 250 \\
\hline 3/10v/93 & $12: 55$ & 24.5 & 40 & 6 & 7.0 & 1,10 & 0.10 & 0.260 & 0.002 & 0.150 & 0.16 & 0.1 & 0.5 & 59.6 & 740 \\
\hline 6/dez/93 & $10: 10$ & 23.0 & 70 & $\because$ & 6.5 & 0.90 & 0,70 & 0,130 & 0.002 & 0.048 & 0.15 & 7.2 & 1.7 & 7.2 & .00 \\
\hline $10 \operatorname{fjan} / 94$ & $11: 30$ & 24.0 & 700 & 150 & 6.7 & 9.00 & 0.10 & 0.130 & 0.002 & 0.020 & 0.10 & 7.1 & 0.5 & 0.8 & 500 \\
\hline $3 / f_{6 \vee} / 9,4$ & $11: 15$ & 23.0 & 70 & 15 & 7,0 & 2,00 & $\begin{array}{l}0,20 \\
0,20\end{array}$ & 0.330 & 0,002 & 0.020 & 0,10 & f., & 2,7 & 9.6 & 13000 \\
\hline 8/mar/94 & $11: 15$ & 20.5 & 120 & 24 & 7.0 & 1.30 & 0.20 & 0.170 & 0,002 & 0.063 & 0.25 & 6,8 & 0.8 & 22,6 & 3.40 \\
\hline S/abs/9.1 & $12: 30$ & 22.0 & 55 & i1 & 7.0 & 1,50 & 0,12 & 0.140 & 0.002 & 0.020 & 0.50 & 7.0 & 0.5 & 4.0 & 620 \\
\hline 4hinaif94 & $12: 10$ & 22.0 & 2.5 & 5,5 & 70 & 1.30 & 0,08 & 0.180 & 0.002 & 0.041 & 1). 10 & 7.3 & 1.0 & 24,0 & 100 \\
\hline 7huore94 & $11: 10$ & & & & & & 0.08 & 0.730 & 0.002 & 0.020 & 0,10 & 7,0 & 2.0 & 9,6 & 140 \\
\hline
\end{tabular}

\begin{tabular}{|c|c|c|c|c|c|c|c|c|c|c|c|c|c|c|c|}
\hline Estatistica Descritiva & Qide resul & 109 & 107 & 108 & 107 & 110 & 109 & 105 & 48 & 99 & 16 & 107 & 102 & 46 & 68 \\
\hline \multirow{4}{*}{ Paramótrica } & Medla & 21.1 & 64,0 & 17,5 & 6.8 & 1.46 & 0.16 & 0.089 & 0.003 & 0.048 & 0.21 & 7.6 & 1.3 & 13,8 & 1786.6 \\
\hline & $\begin{array}{l}\text { Med. Geon } \\
\text { Moda }\end{array}$ & 20.9 & 46,7 & 11.3 & 6,7 & 1,17 & 0.10 & 0,047 & 0,002 & 0.018 & 0.17 & 7.5 & 0,8 & 8.2 & 477,6 \\
\hline & $\mid \begin{array}{l}\text { Moda } \\
\text { Desvio } P_{31}\end{array}$ & 23,0 & 10,0 & 6,0 & 7.0 & 1.40 & 0,05 & 0.010 & 0.002 & 0.020 & 0,10 & 7,2 & 0.5 & 2.0 & 300,0 \\
\hline & $\begin{array}{l}\text { Uesvio } P_{3 i} \\
\text { Coof Varia }\end{array}$ & $\begin{array}{l}2.8 \\
0,1\end{array}$ & $\begin{array}{c}77,0 \\
1,2\end{array}$ & $\begin{array}{c}23,0 \\
1,3\end{array}$ & 0.3 & $\begin{array}{l}1,48 \\
1.0\end{array}$ & 0,57 & 0,090 & 0,008 & 0.079 & 0.13 & 39.8 & 1,2 & 16,2 & $\$ 112.6$ \\
\hline \multirow{5}{*}{ Nào-Paramétrica } & Minimo & 14.0 & 5,0 & $\frac{1,3}{2.3}$ & $\frac{0.0}{5.1}$ & $\frac{1.0}{0.11}$ & 3.5 & 1,1 & 2,5 & 1.6 & 0.6 & 0.1 & 0.9 & 12 & 2.3 \\
\hline & Quartil $\uparrow$ & 19,0 & 30.0 & 6.0 & 5,6 & 0.80 & $\begin{array}{l}0,04 \\
0,06\end{array}$ & 0,001 & 0.001 & 0.001 & 0.03 & 6.1 & 0,1 & 2.0 & 18,0 \\
\hline & Mediana & 22.0 & 40,0 & 9.0 & 6.8 & 1,60 & 0.00 & 0.027 & 0,002 & 0.008 & 0.10 & 7.1 & 0,5 & 4.1 & 216.3 \\
\hline & Quarlil 3 & 23.0 & 70.0 & 17.0 & 7.0 & 1.50 & 0,14 & 0.067 & 0.002 & 0.020 & 0.17 & 7,5 & 0.9 & 7.2 & 320,0 \\
\hline & Háximo & 29,0 & 7000 & 150,0 & 7.4 & 11,00 & 6.00 & $\begin{array}{l}0.120 \\
0.730\end{array}$ & 0,002 & 0.047 & 0.20 & 8.1 & 1.7 & 15,8 & 745.0 \\
\hline
\end{tabular}


ANEXO 3 - DADOS BRUTOS DAS VAZÕES EM DIOGO E SERRA AZUL

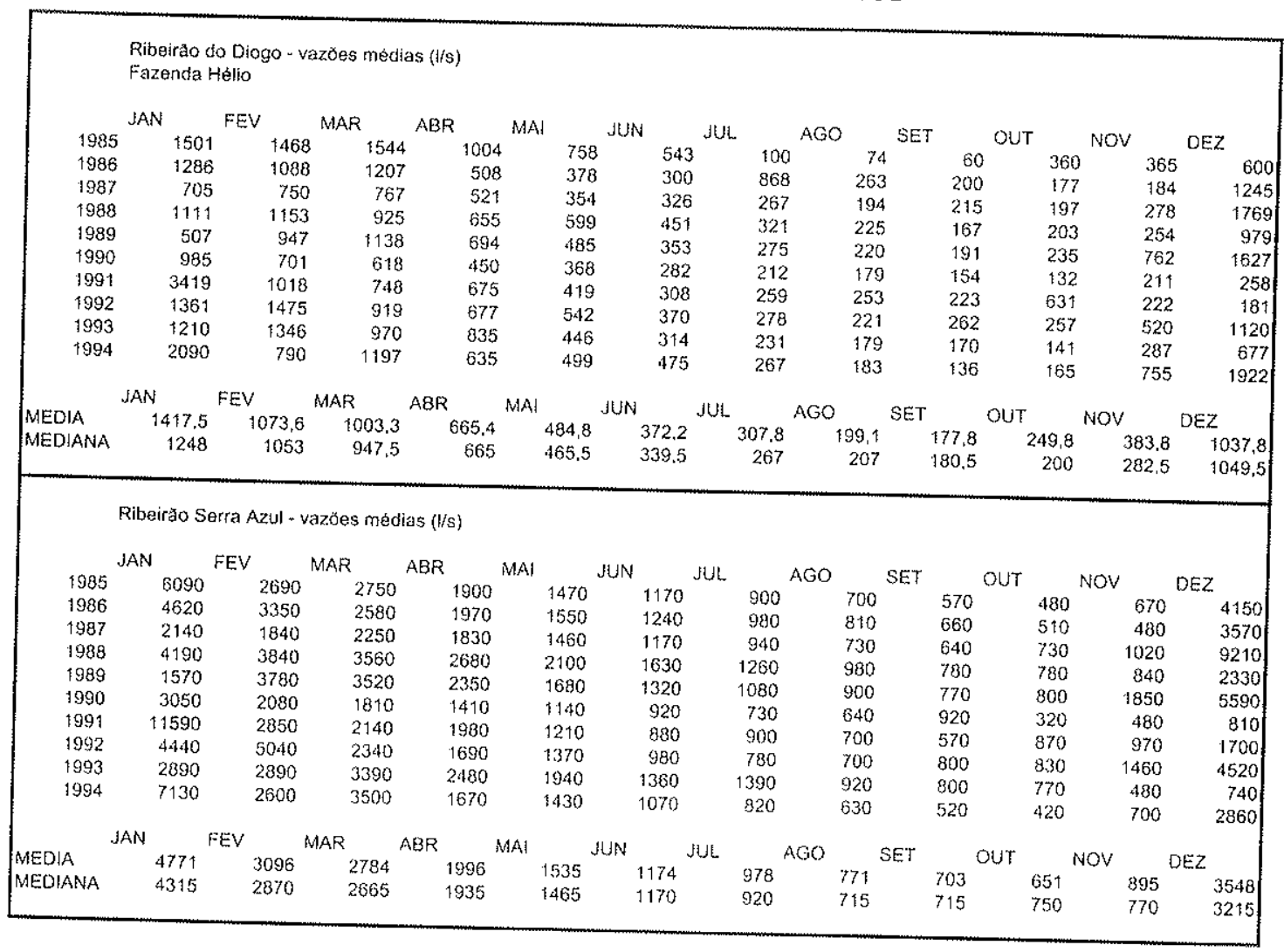



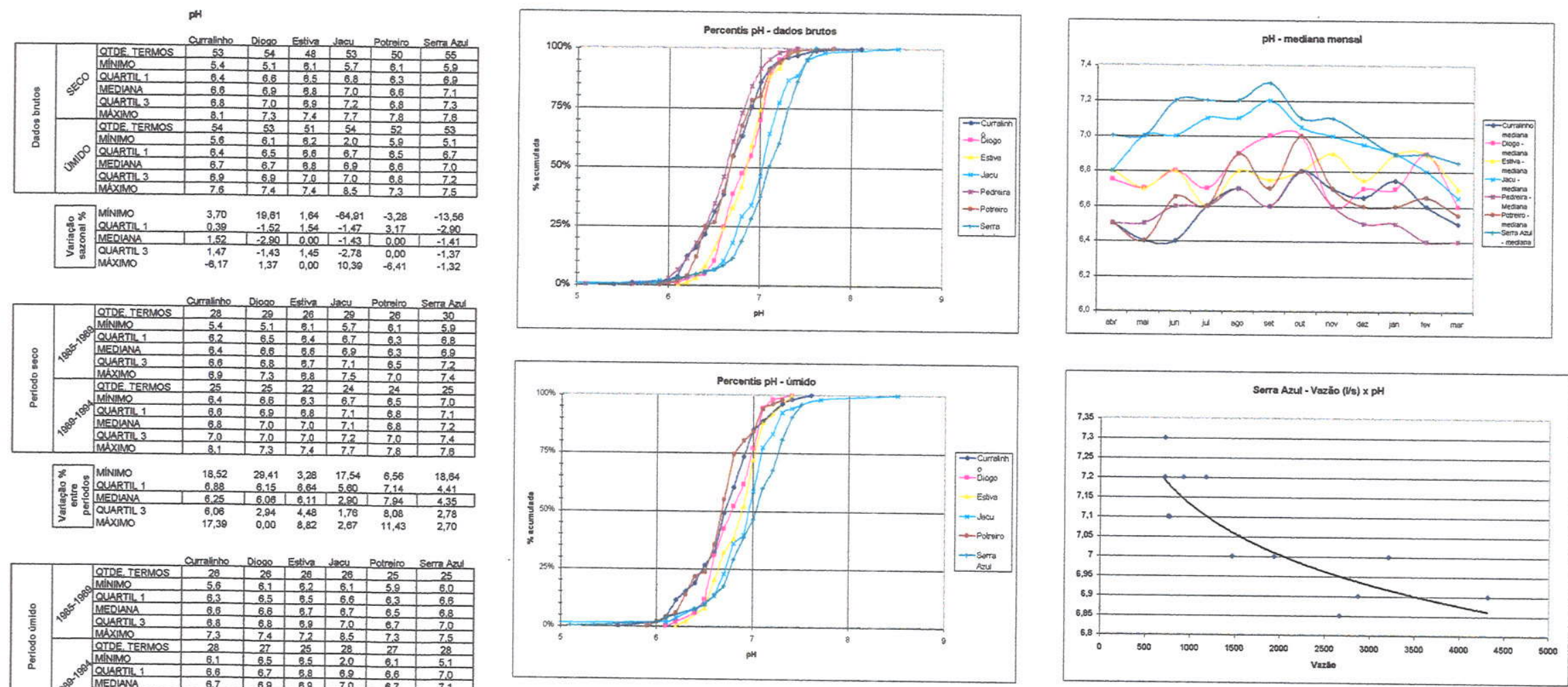

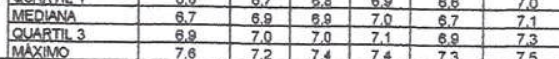
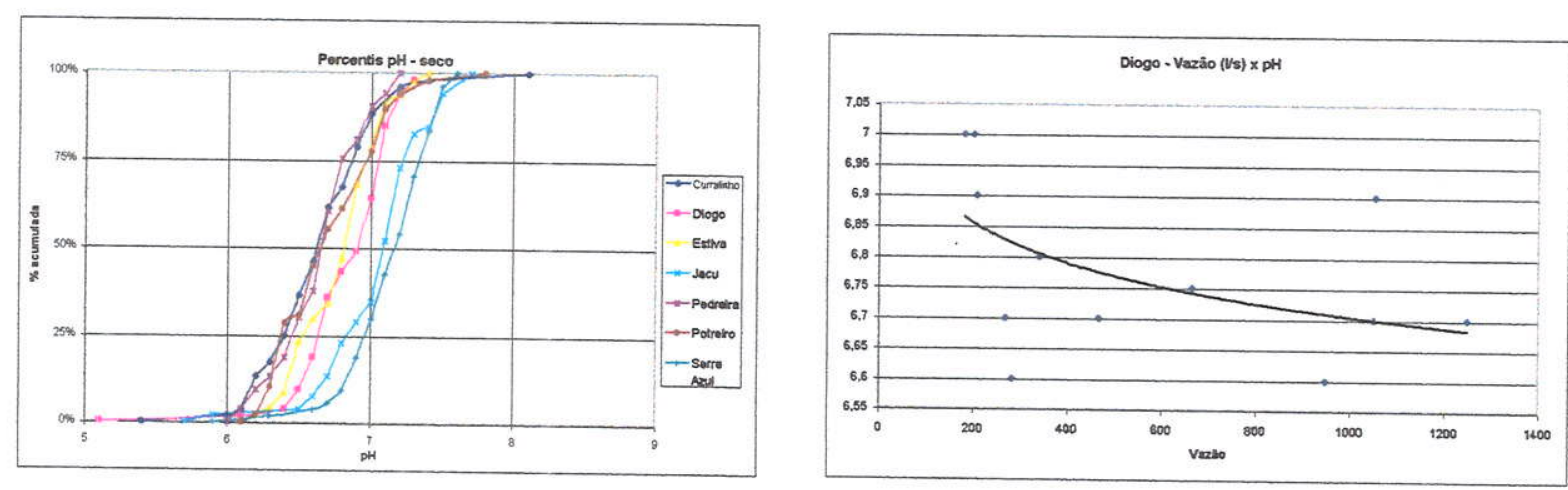


\section{Ptotal (mol P)}

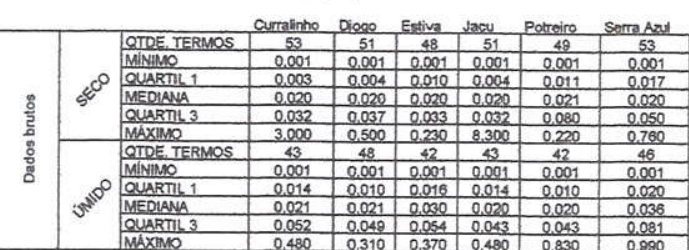

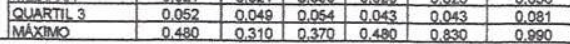

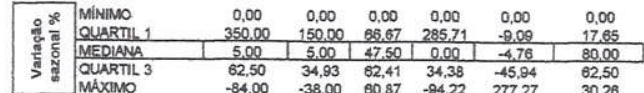

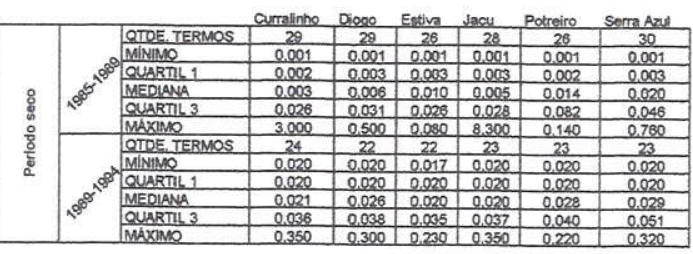

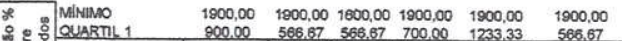

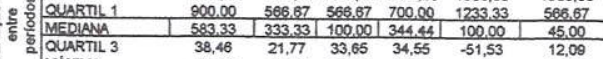

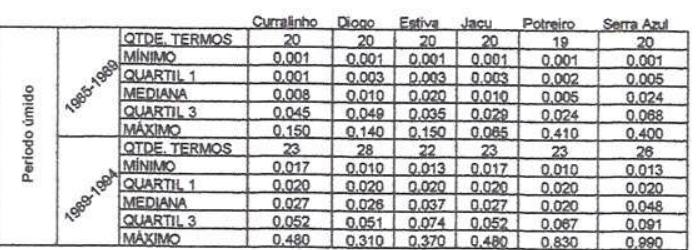

\begin{tabular}{|lllllll}
\hline 0.052 & 0.051 & 0.074 & 0.052 & 0.067 & 0.091 \\
\hline
\end{tabular}

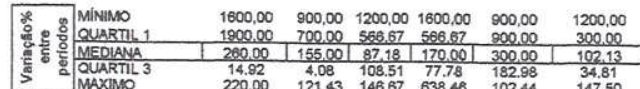

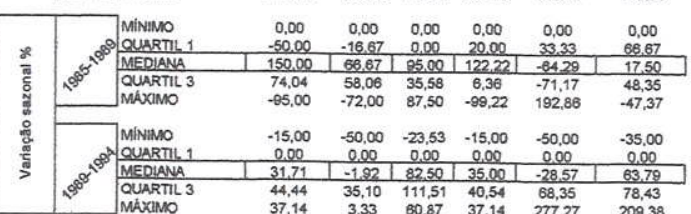
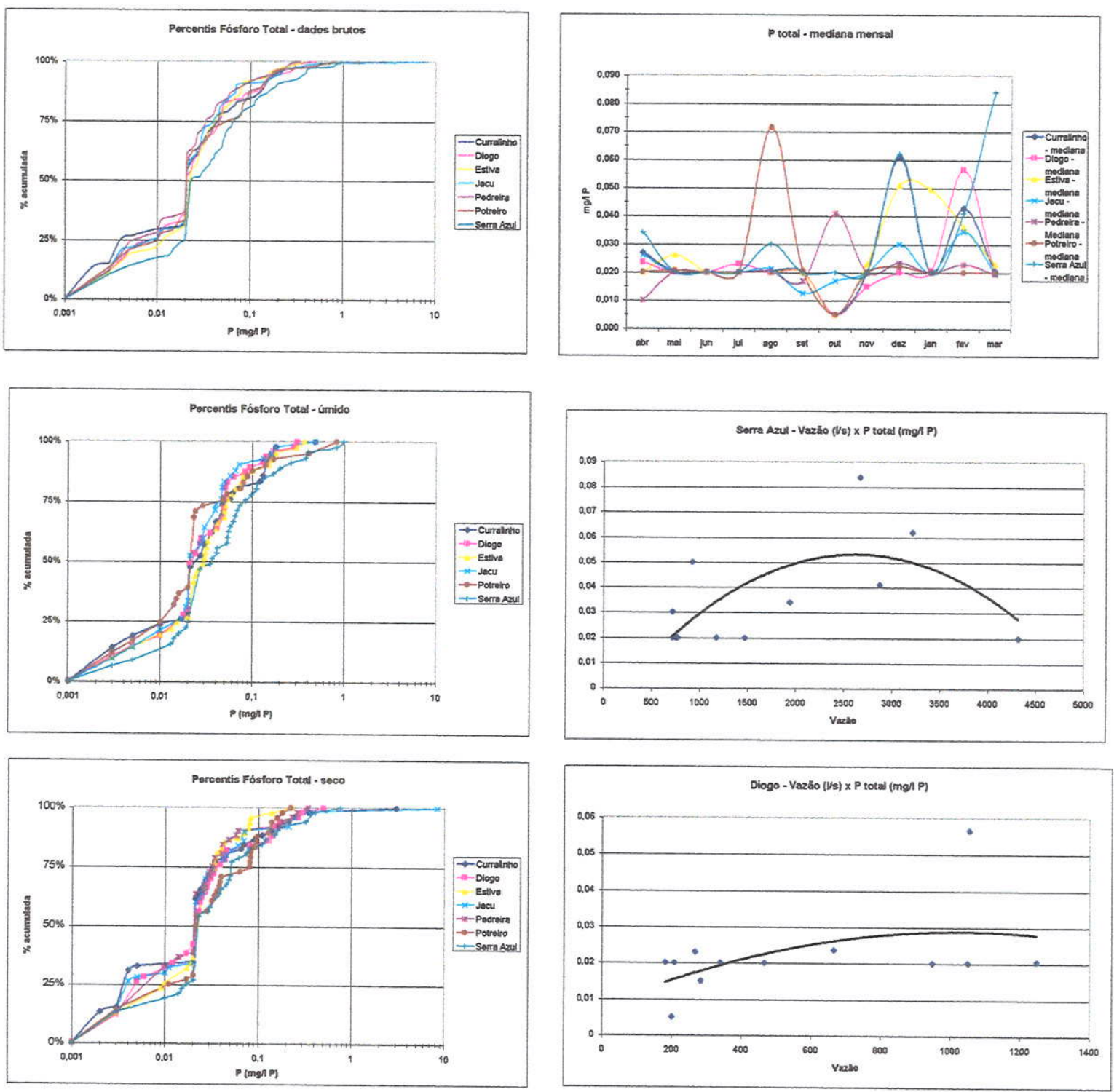


\section{ss (mol)}

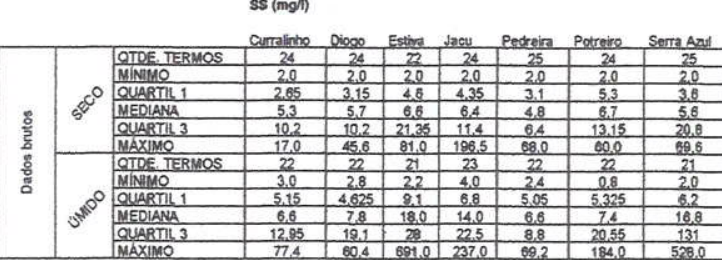

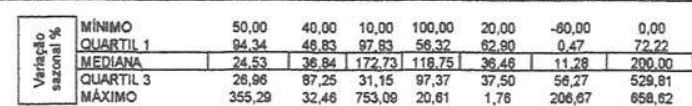

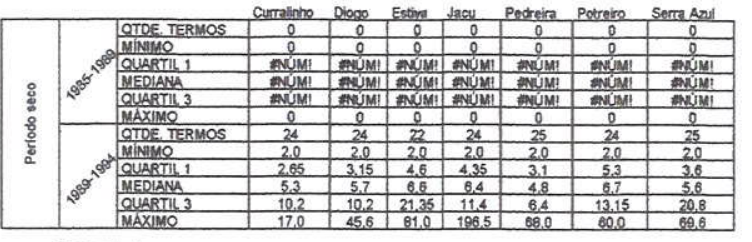

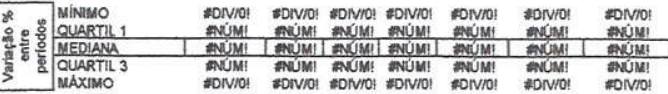

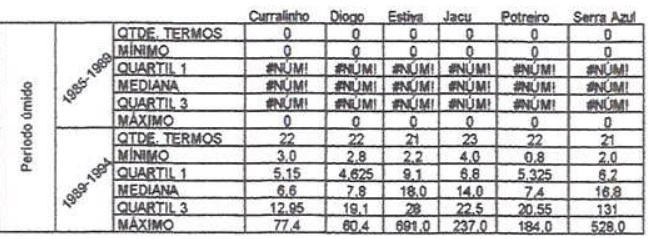

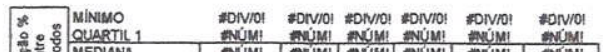

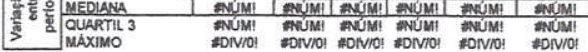

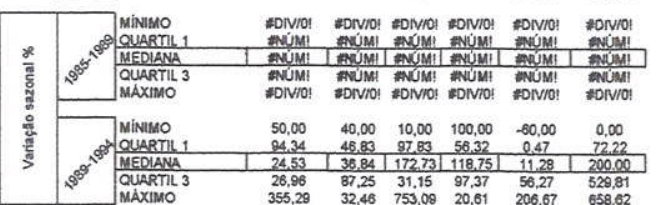
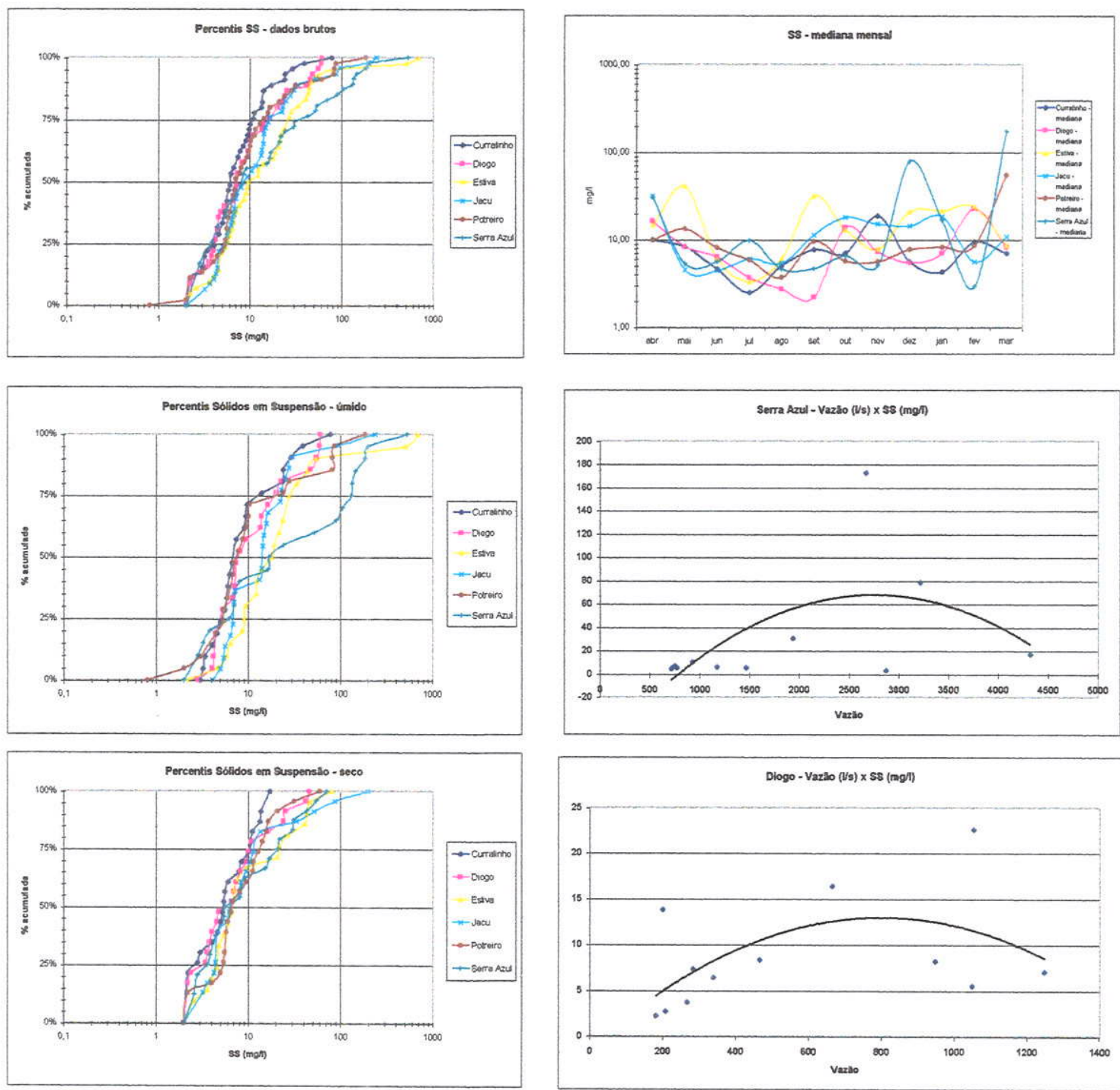
Turbidez (NTY)

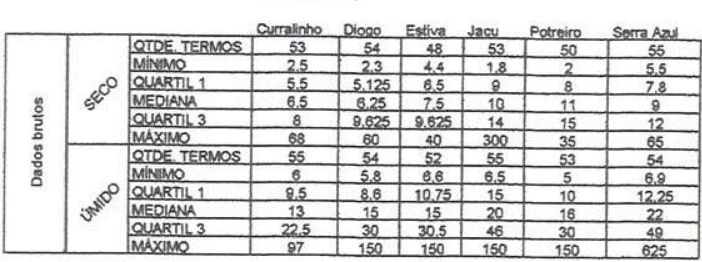

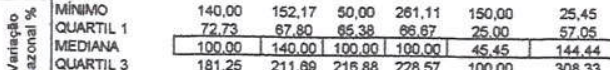

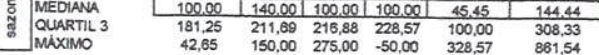
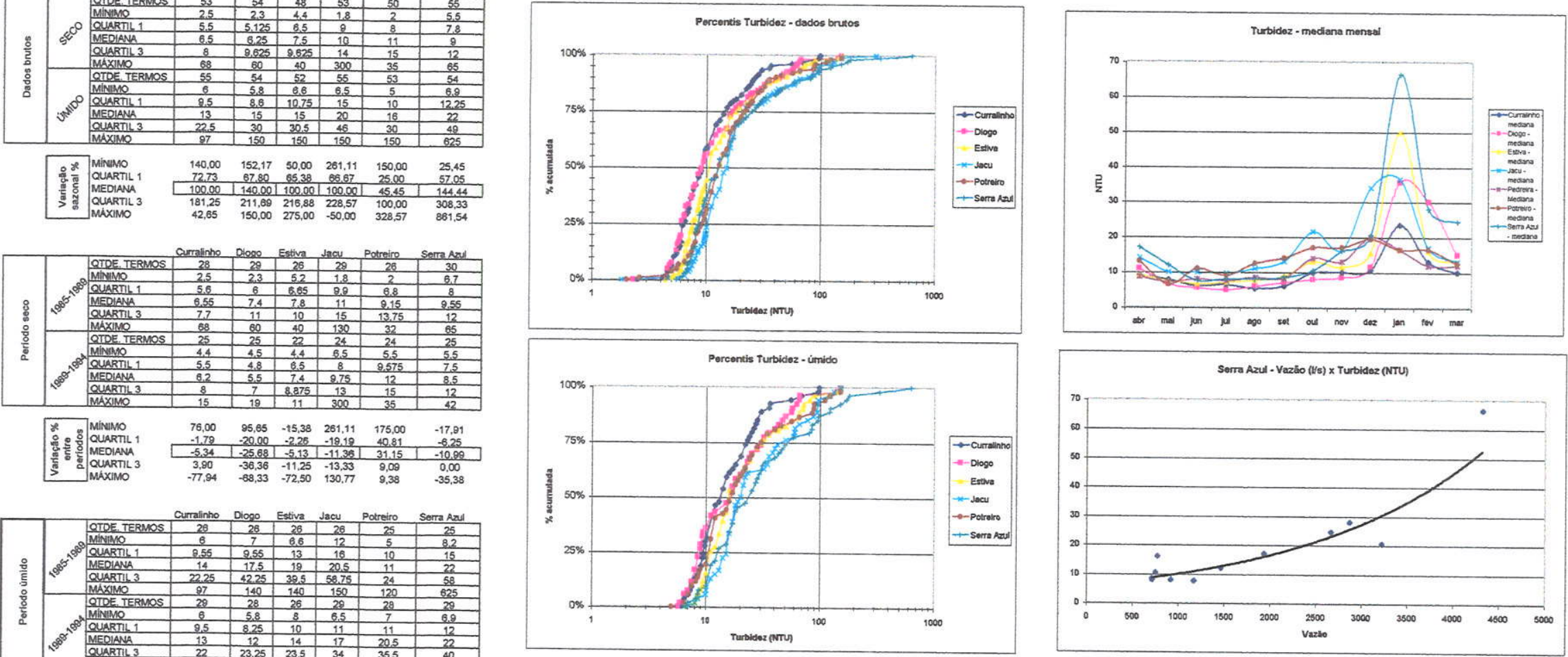

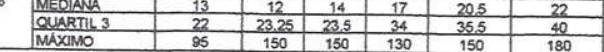

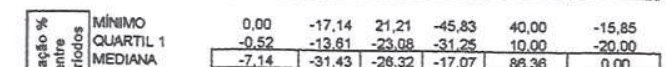
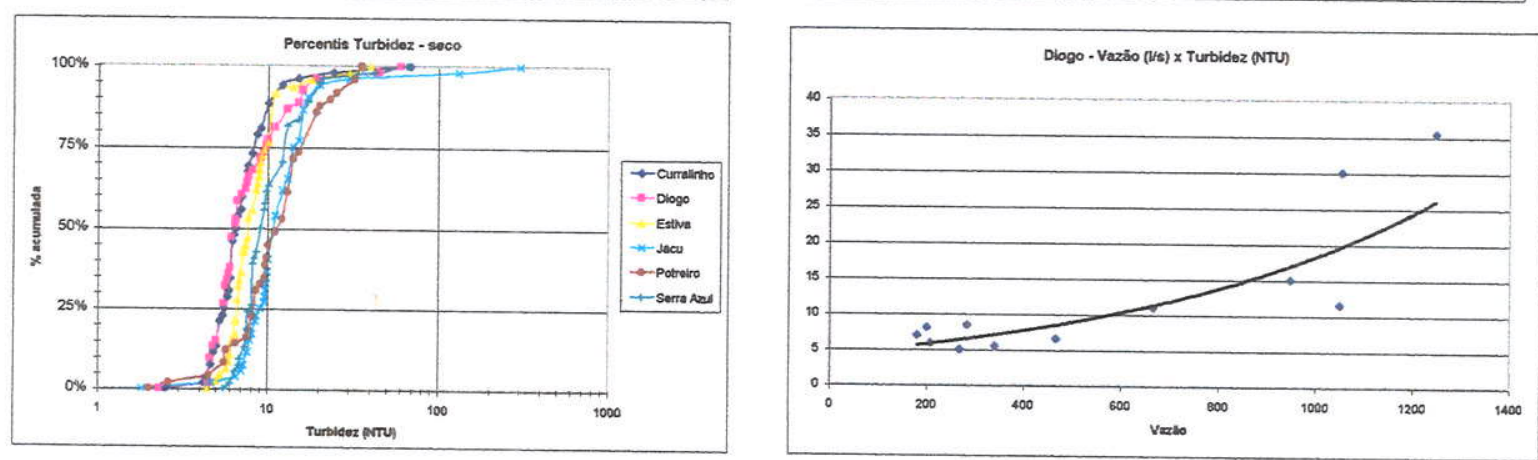

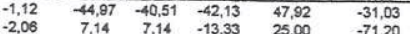

$\begin{array}{llllll}140,00 & 204,35 & 28,92 & 568,67 & 150.00 & 22,39\end{array}$

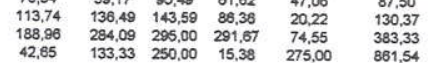

$\begin{array}{lllll}36,36 & 28.89 & 81.82 & 0.00\end{array}$

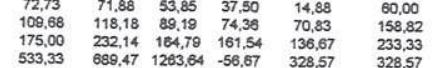

10 Turbocer antu 
ANEXO 4- RESUMO DA INFERENCIA ESTATISTICA

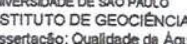
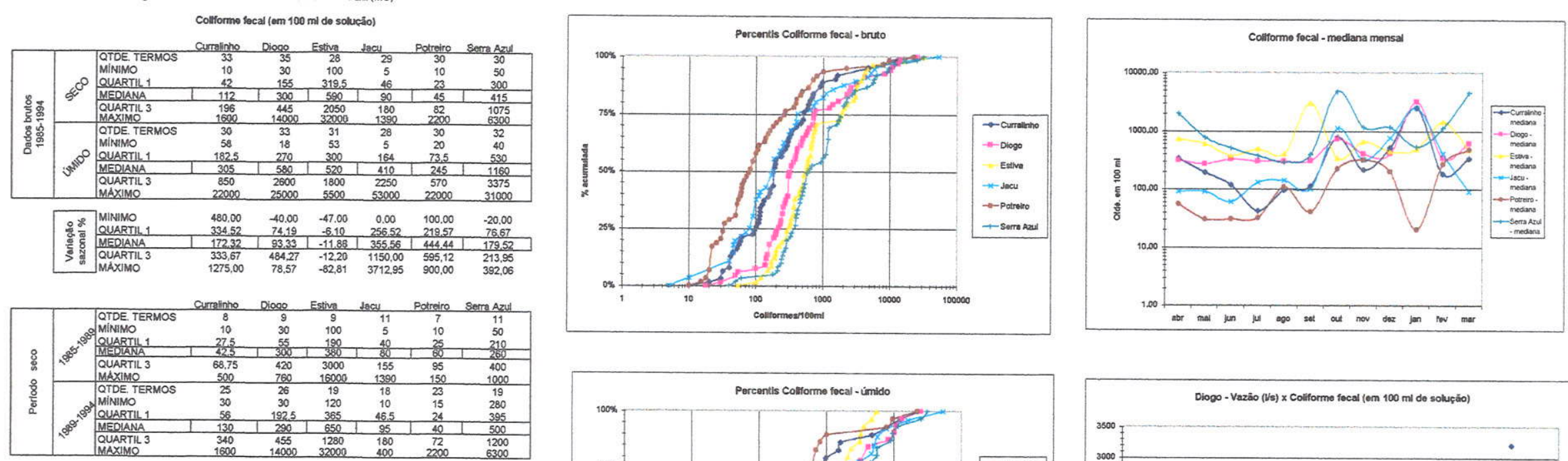

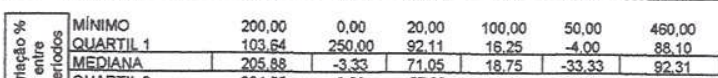

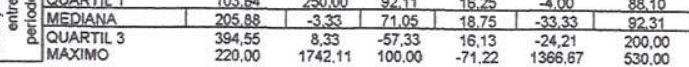
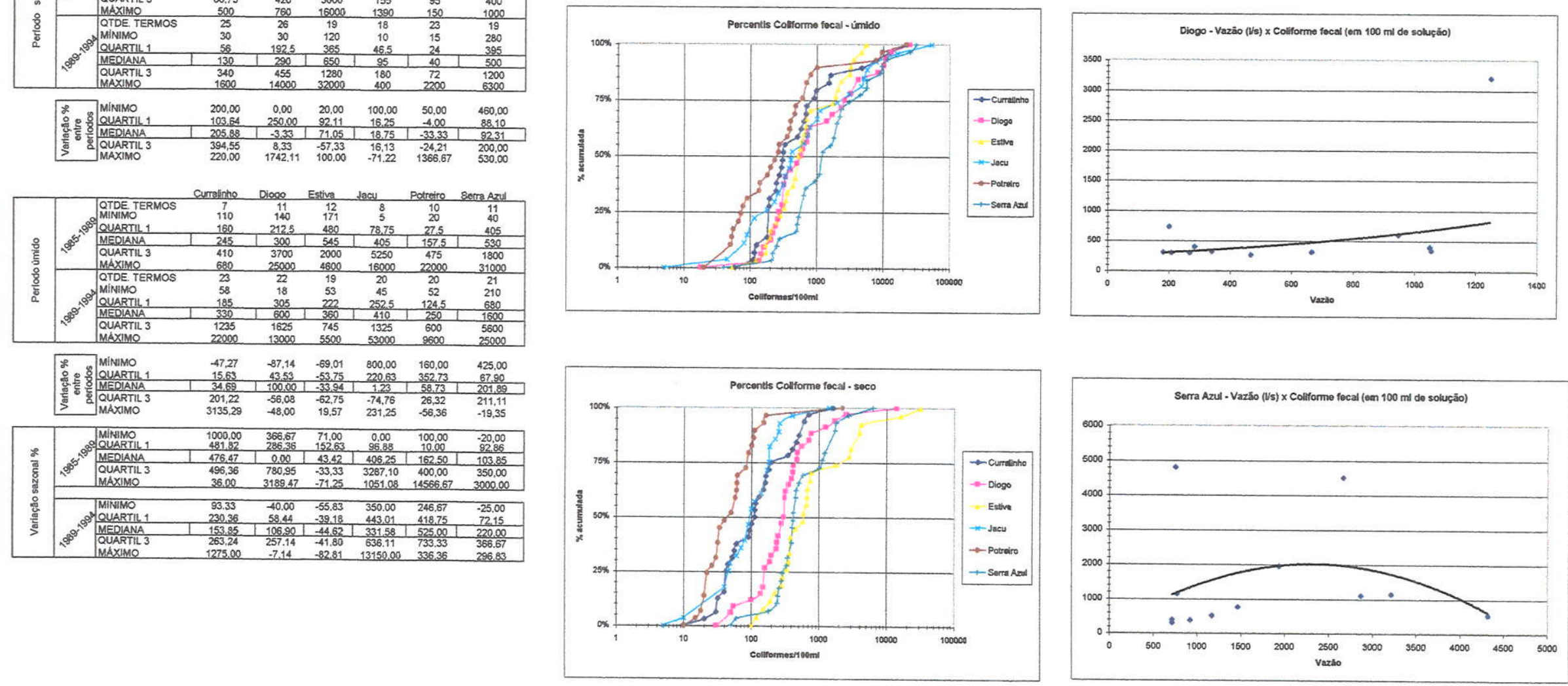
Cor (UPT)

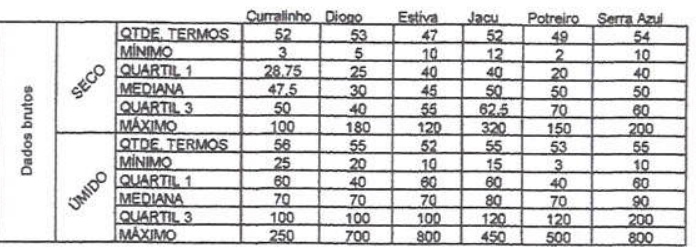

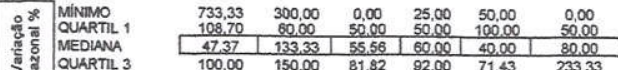

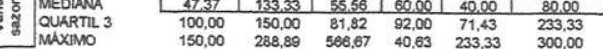

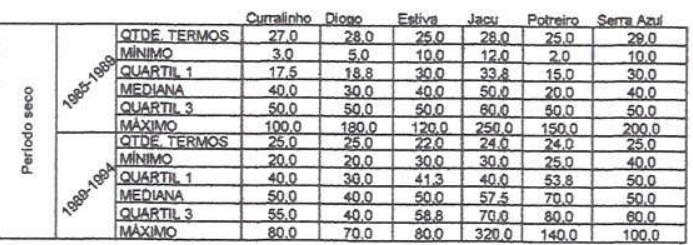

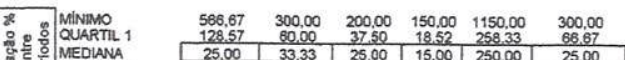

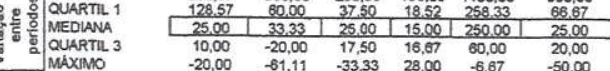

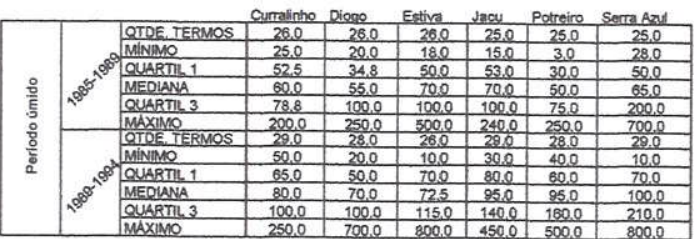

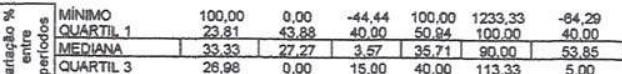

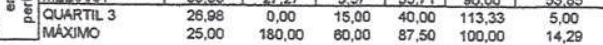

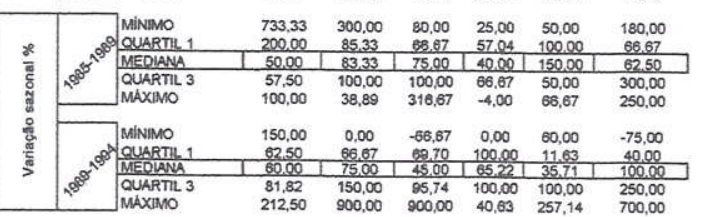
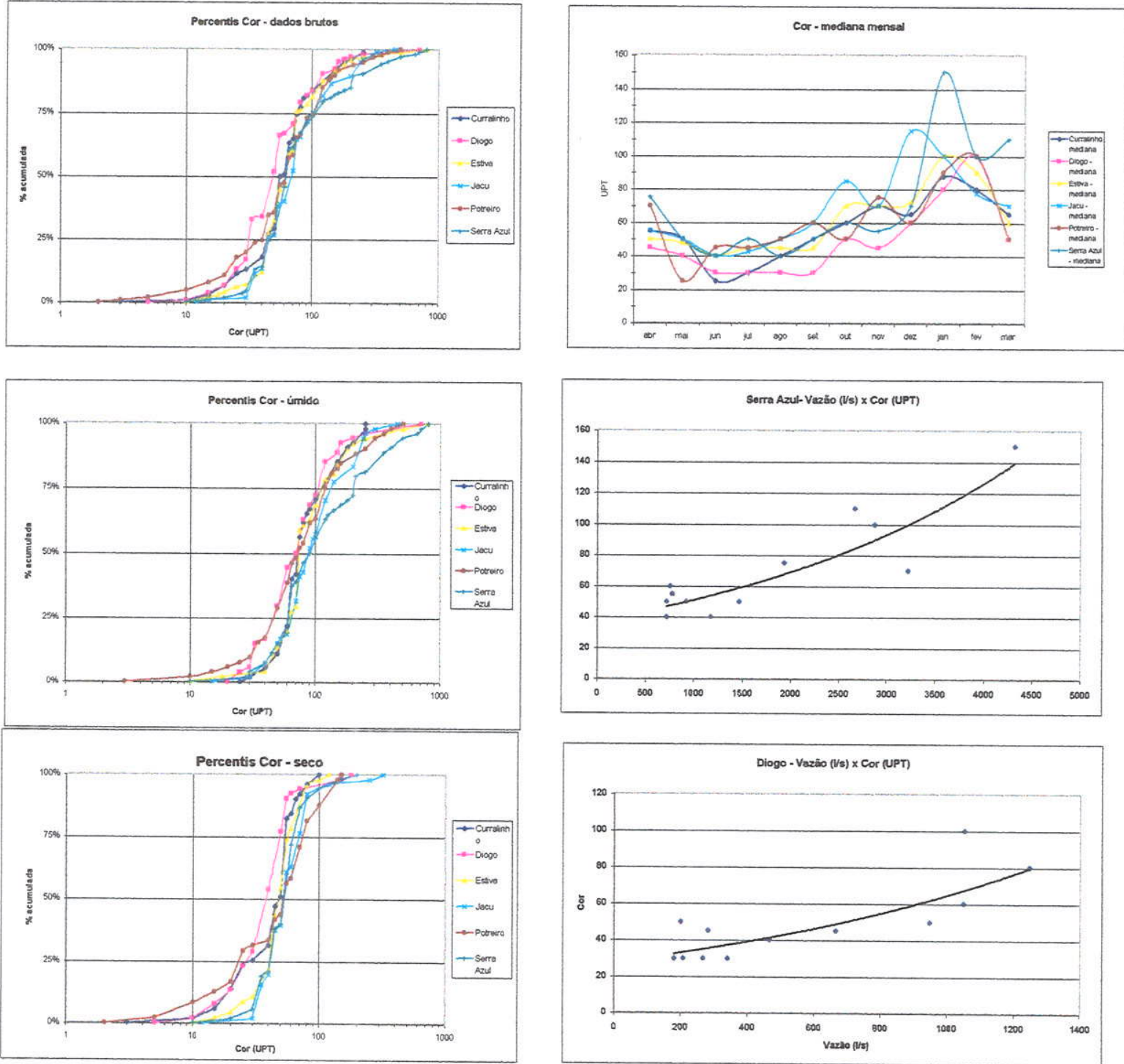


\section{OBO (mor 02)}

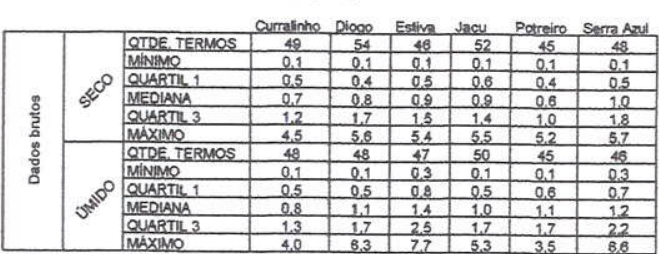

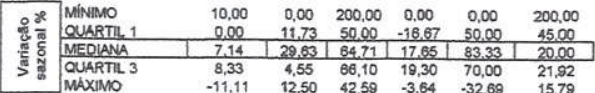

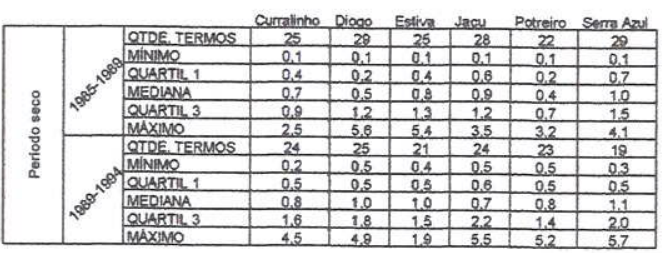

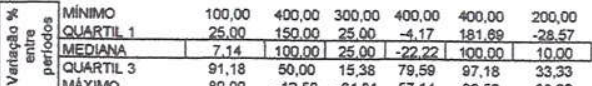

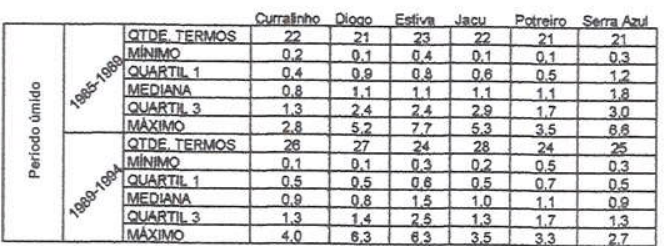
\begin{tabular}{llllllll}
\hline 5 & Minimo & $-45,00$ & 0.00 & $-25,00$ & 100,00 & 400,00 & 0.00
\end{tabular}

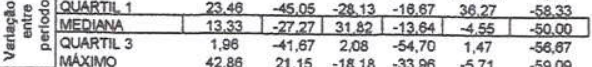

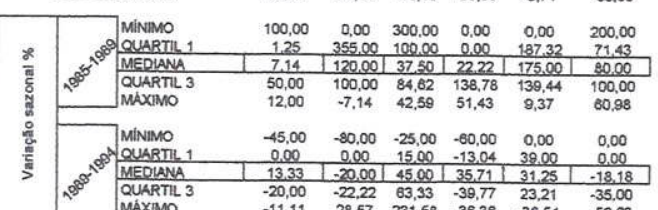

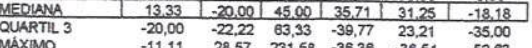
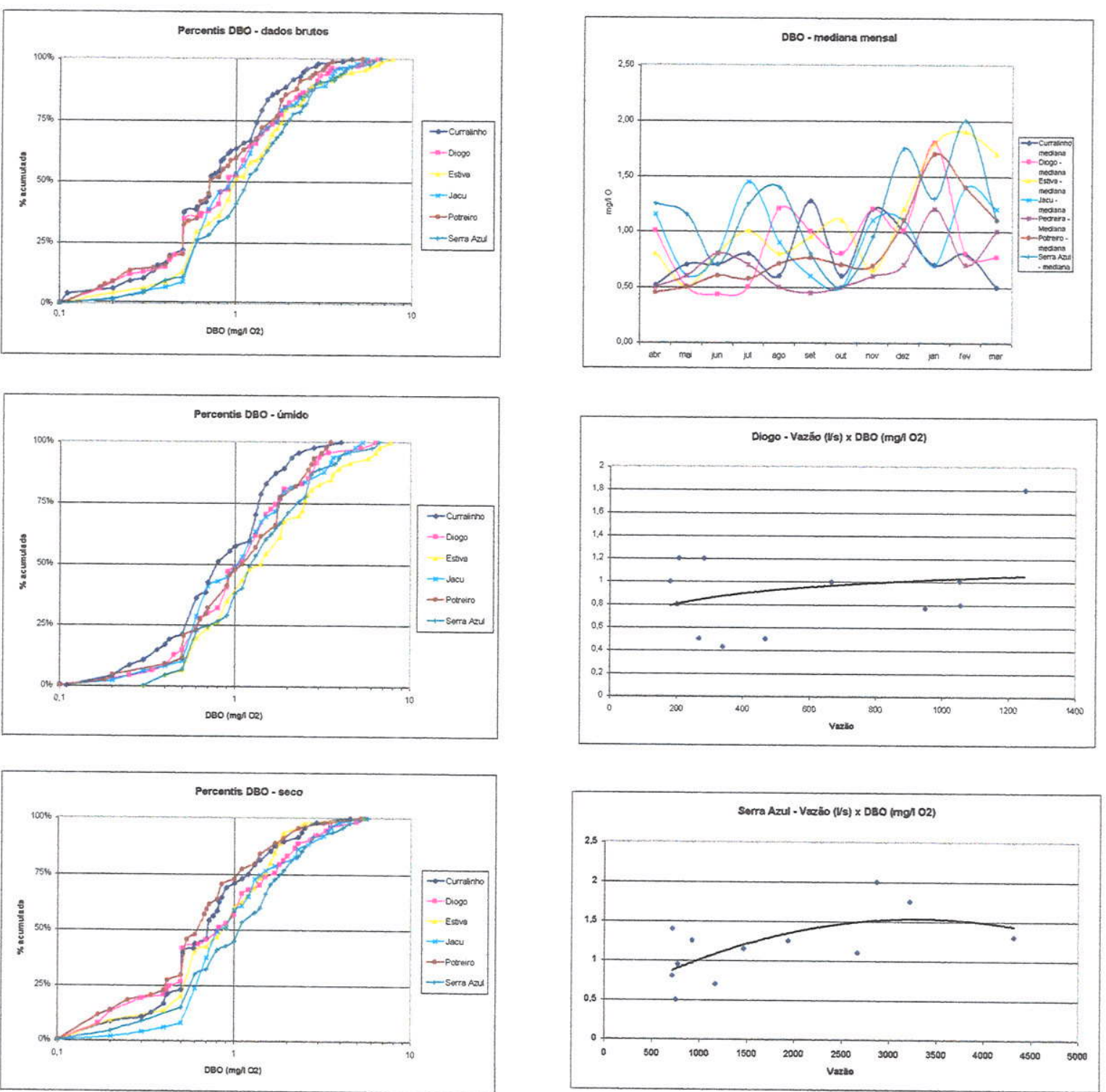

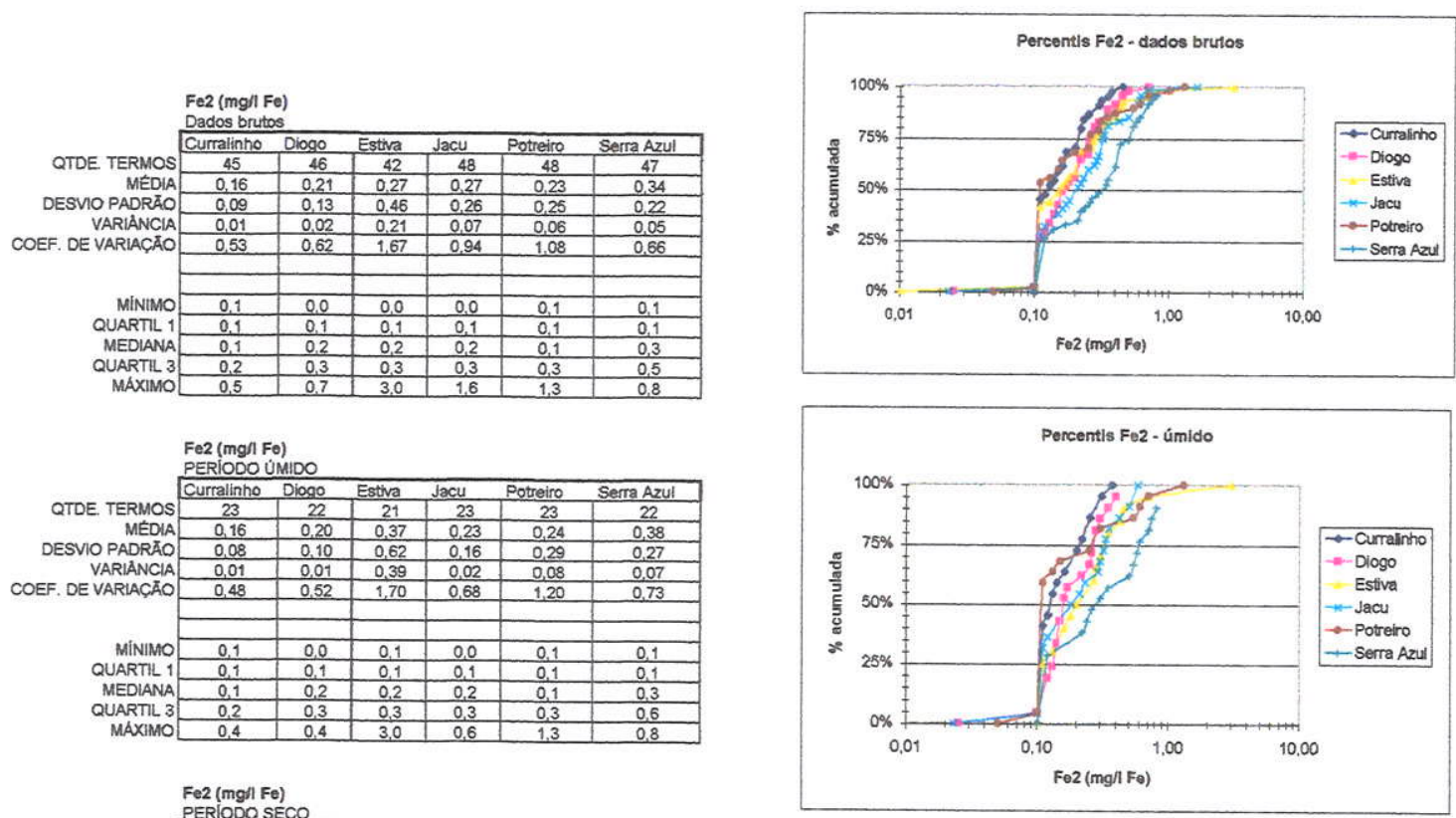

\section{Fe2 (mon Fo)}

QTDE TERMOS \begin{tabular}{|c|c|c|c|c|c|c|}
\hline Curralinho Diogo & Estiva & Jacu & Potreito & Serra AZU1 \\
22 & 24 & 21 & 25 & 25 & 25 \\
\hline
\end{tabular} \begin{tabular}{c|c|c|c|c|c|c|}
\hline MEDAA & 22 & 24 & 21 & 25 & 25 & 25 \\
\hline & 0.18 & 0.18 & 0.31 & 0.22 & 0.30 \\
\hline
\end{tabular}

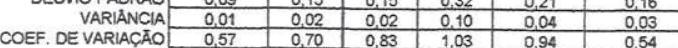

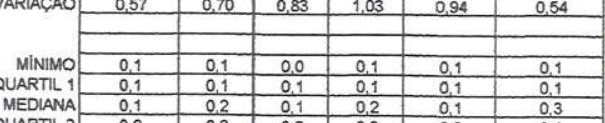

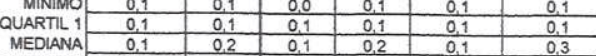
\begin{tabular}{l|c|c|c|c|c|c|} 
MUEDRLA & 0.1 & 0.2 & 0.1 & 0.2 & 0.1 & 0.3 \\
\hline MAXXIMO & 0.2 & 0.3 & 0.2 & 0.3 & 0.3 & 0.4 \\
\hline 0.5 & 0.7 & 0.7 & 1.6 & 1.0 & 0.6 \\
\hline
\end{tabular}
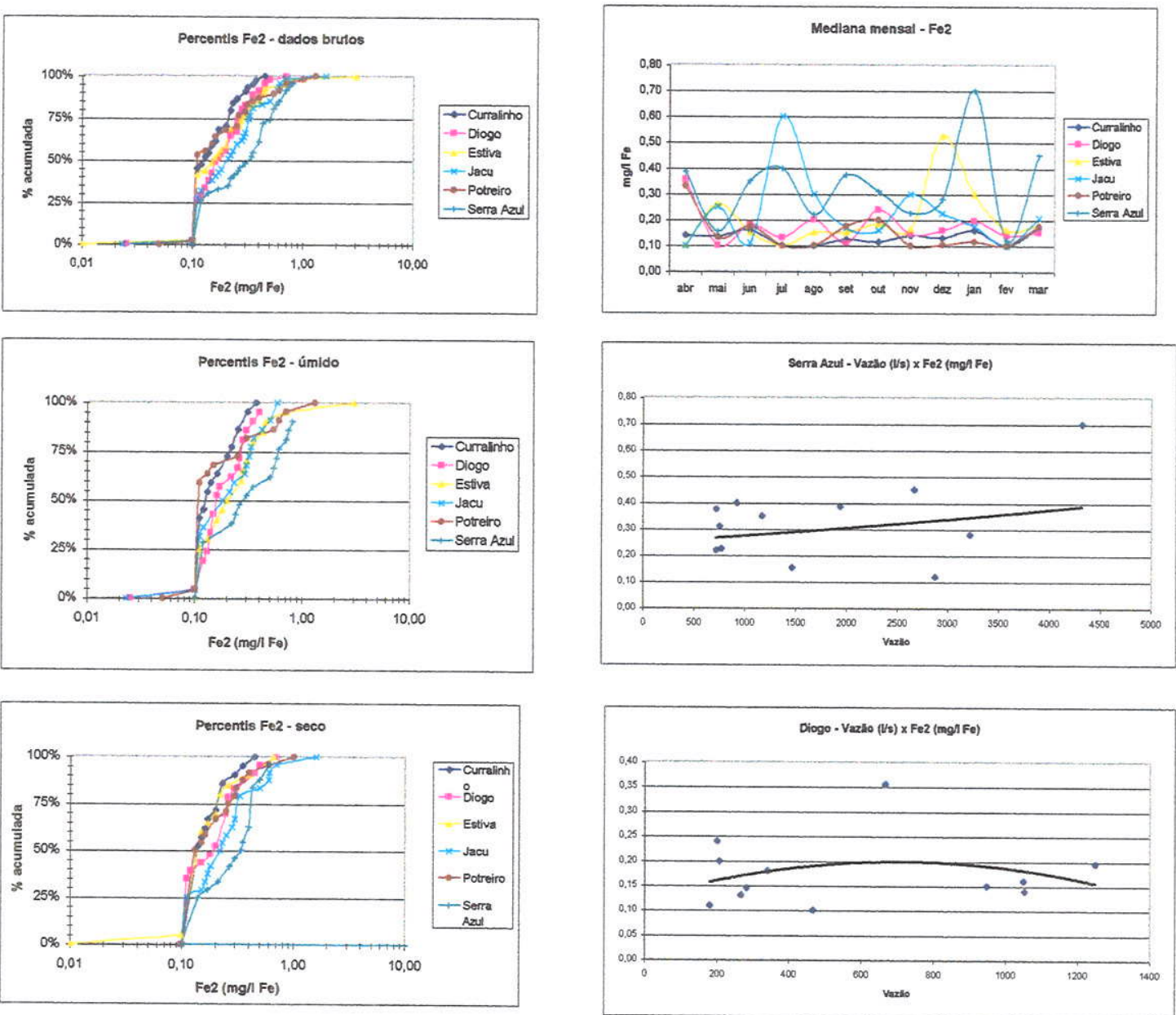

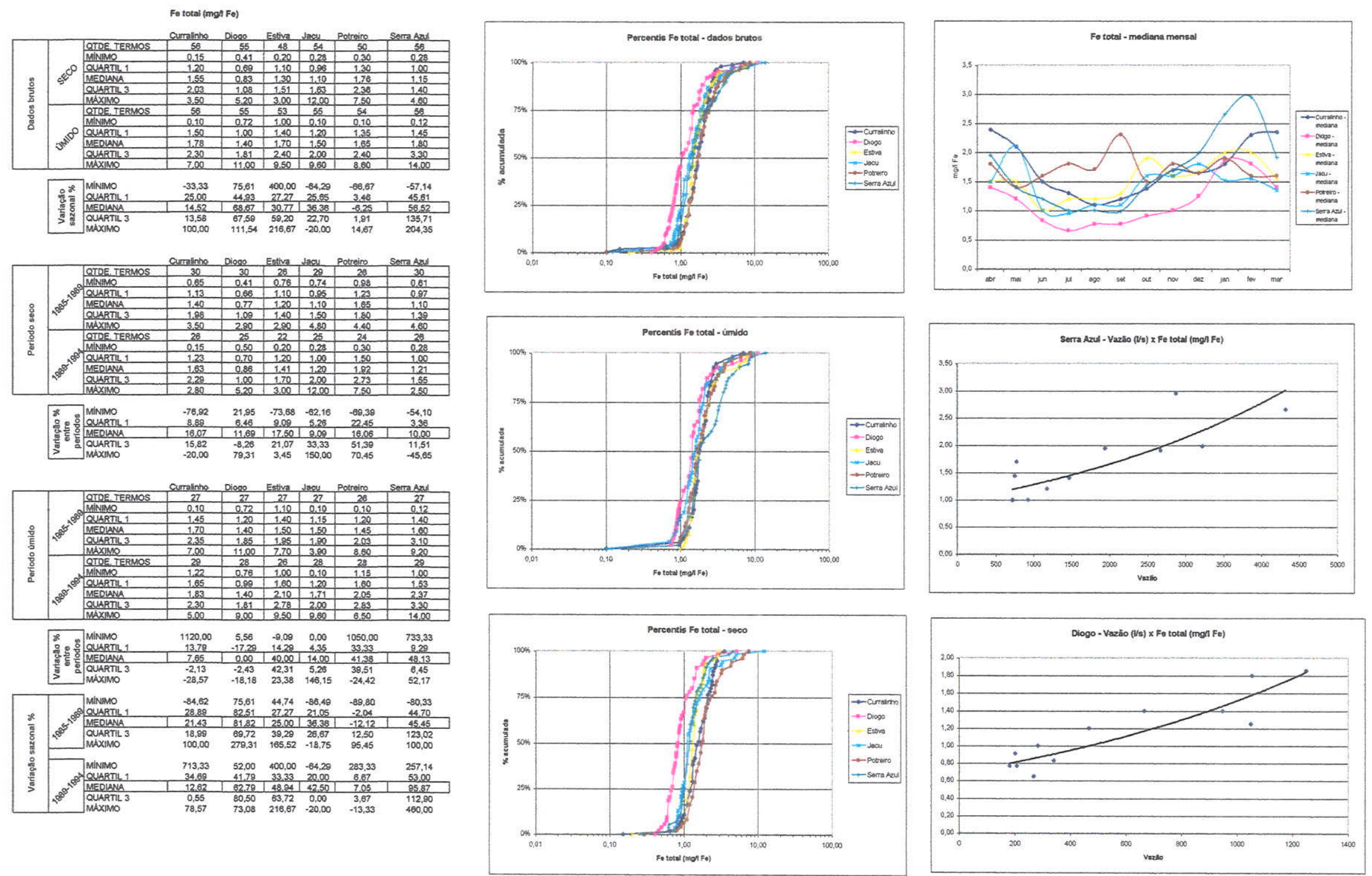


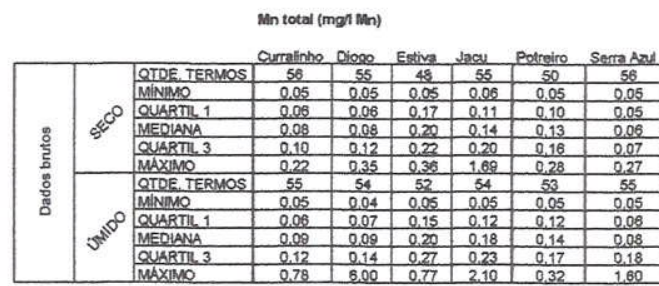

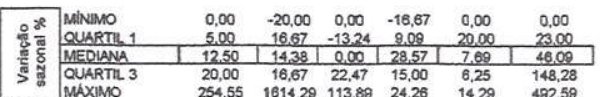

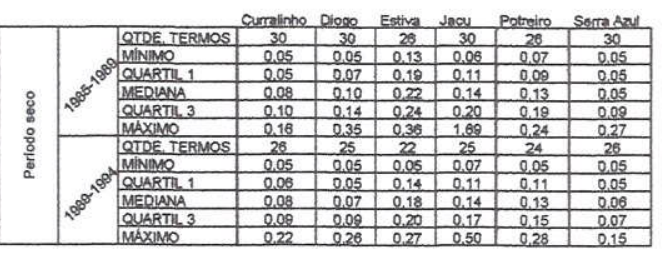

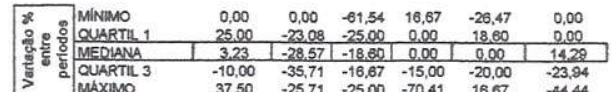
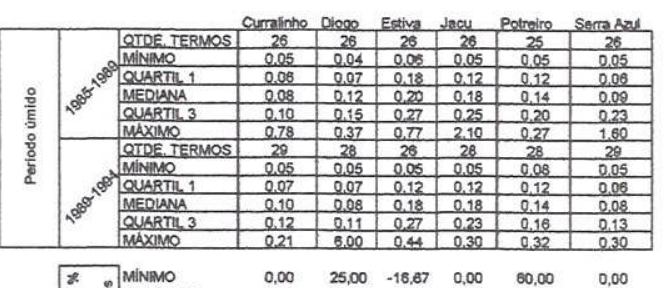

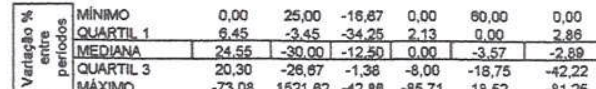

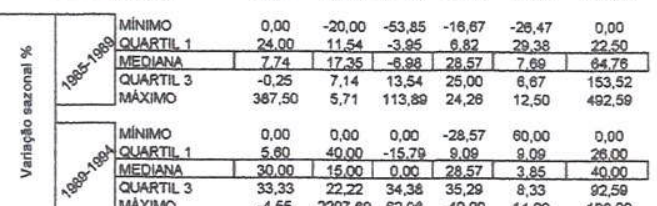
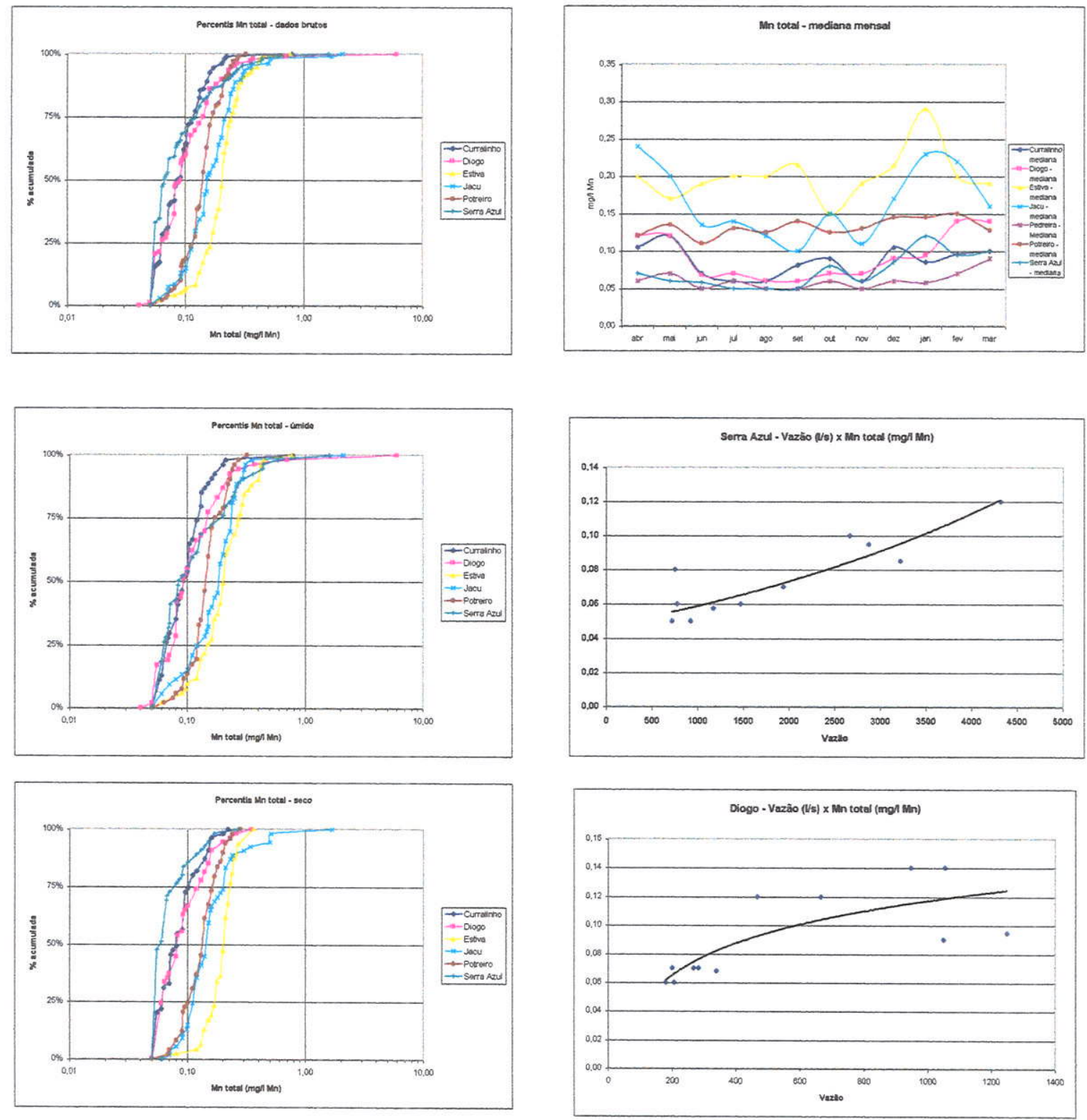
ANEXO 4 - RESUNO DA INFERENCIA ESTATISTICA

UNVERSDADE DE SAO PAULO

Dissertaça: Qualidade dâ Água e Uso do solo na Bacia do Riberão Serra Azul (MG)

\begin{tabular}{|c|c|c|c|c|c|c|}
\hline \multirow[b]{2}{*}{ OTDE. TERMOS } & \multicolumn{6}{|c|}{\begin{tabular}{|l} 
Nitrito (mg/n N) \\
Dados brutos
\end{tabular}} \\
\hline & 48 & 48 & 42 & 49 & 48 & 48 \\
\hline MEDIA & 0.002 & 0,003 & 0,007 & 0,002 & 0,003 & $0,0,3$ \\
\hline DES & 0.001 & 0.008 & 0,031 & 0.001 & 0,003 & 0,002 \\
\hline & 0.000 & 0.000 & 0,001 & 0,000 & 0.000 & 0,000 \\
\hline COEF, DE VARIAÇĀO & 0.346 & 2.549 & 4.331 & 0,346 & 1.1688 & 0,748 \\
\hline & & & & & & \\
\hline MiNiMO & 0,001 & 0,001 & 0,002 & 0.001 & 0,001 & 0.001 \\
\hline & 0,002 & 0,002 & 0.002 & 0,002 & 0.002 & 0,002 \\
\hline$M=D A A$ & 0.002 & 0.002 & 0.002 & 0,002 & 0,002 & $0,0,02$ \\
\hline QUARTIL 3 & 0,002 & 0,002 & 0.002 & 0,002 & 0,002 & 0,002 \\
\hline MÄXIMO & 0,006 & 0.060 & 0,200 & 0,006 & 0.020 & 0,011 \\
\hline
\end{tabular}

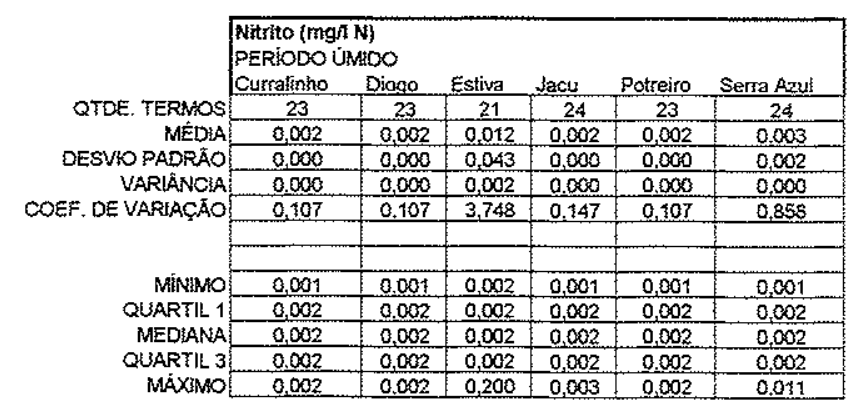

\begin{tabular}{|c|c|c|c|c|c|c|}
\hline \multirow{2}{*}{ QTDE, TERNOS } & \multicolumn{6}{|c|}{$\begin{array}{l}\text { Nitrito (migh N) } \\
\text { PERIODO SECO }\end{array}$} \\
\hline & $\frac{\text { Curralinho }}{25}$ & $\frac{\text { Diogo }}{25}$ & Estiva & Jacu & $\frac{\text { Potreiro }}{25}$ & $\frac{\text { Serra } A z u}{24}$ \\
\hline MEDDIA & 0,002 & 0,005 & 0,003 & $\frac{20}{0.002}$ & 0.004 & $0,0,02$ \\
\hline HO PADRÁO & 0,001 & 0,012 & 0,002 & 0.001 & 0,005 & 0,001 \\
\hline VARLÄNCIA & 0,000 & 0,000 & 0,000 & 0.000 & 0,000 & 0,000 \\
\hline EF. DE VARIAÇAO & 0,426 & 2,567 & 0,597 & 0,422 & 1,200 & 0.566 \\
\hline & & & & & & \\
\hline NIMO & 0,002 & 0.002 & 0,002 & 0.002 & 0,002 & 0,002 \\
\hline QUAS & 0,002 & 0.002 & 0,002 & 0.002 & 0.002 & 0,002 \\
\hline$M=D E A$ & 0,002 & 0,002 & 0,002 & 0,002 & 0,002 & 0,002 \\
\hline & 0,002 & 0,002 & 0,002 & 0,002 & 0.002 & 0,002 \\
\hline MAXIMO & 0.006 & 0,060 & 0.008 & 0,006 & 0.020 & 0.008 \\
\hline
\end{tabular}
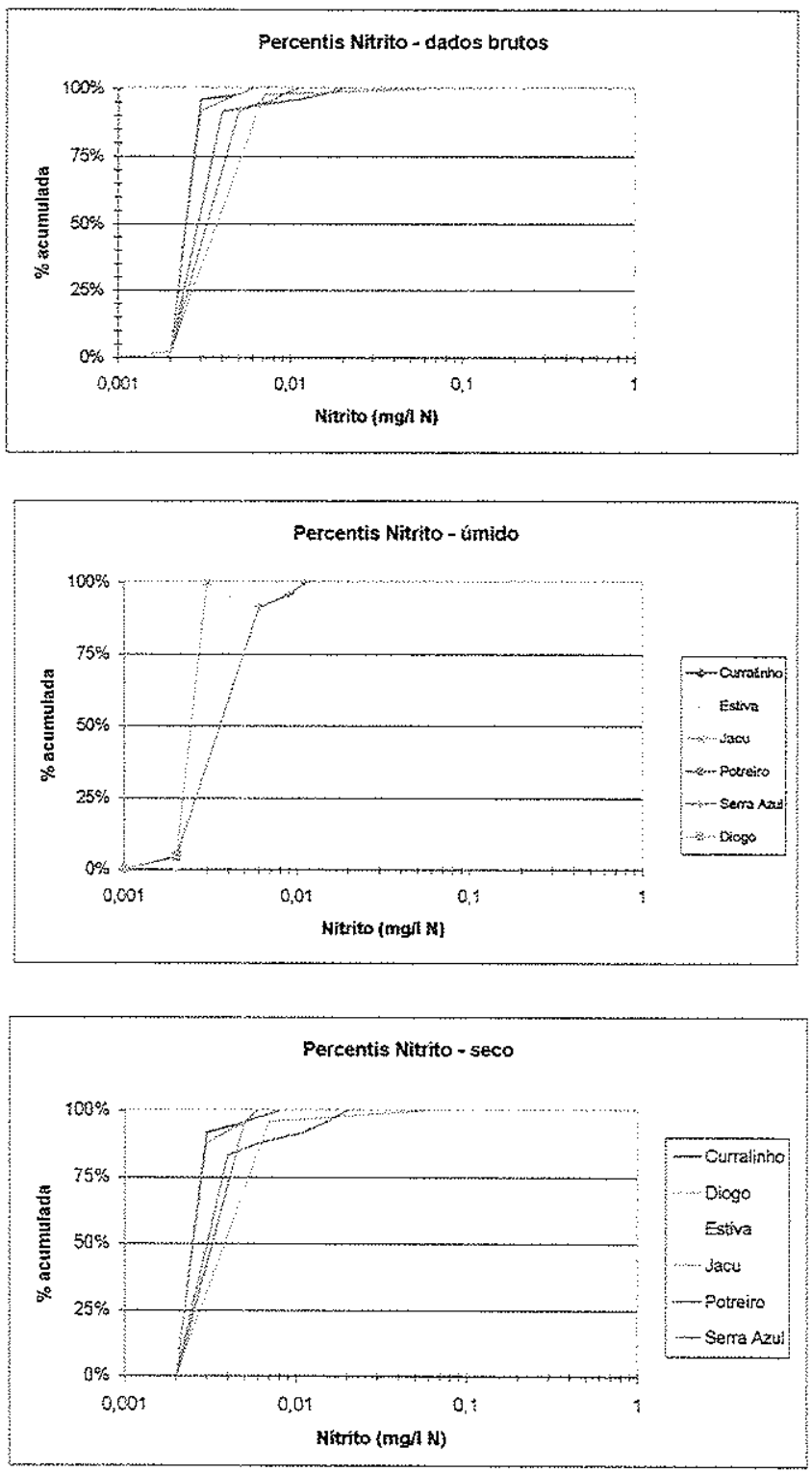
erato (mol M

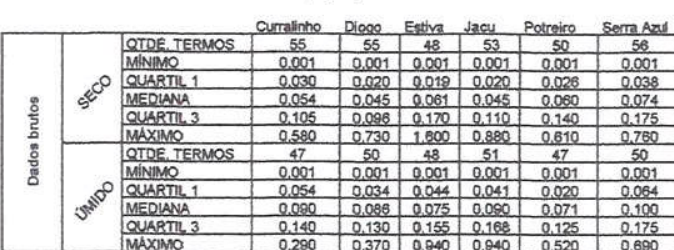

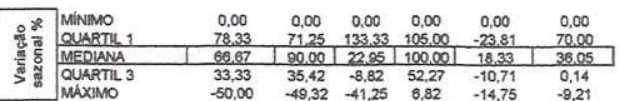

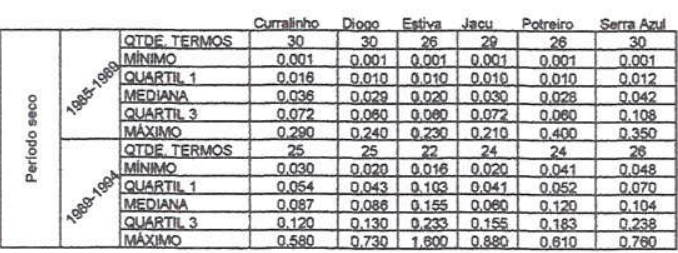

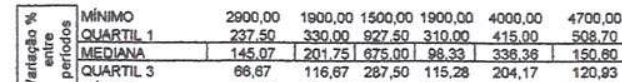

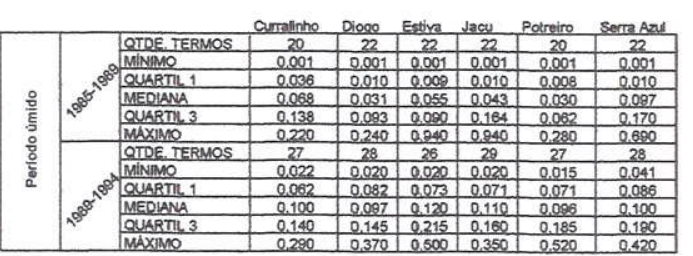

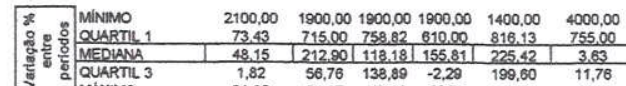

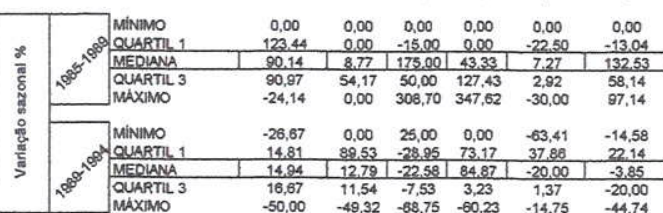
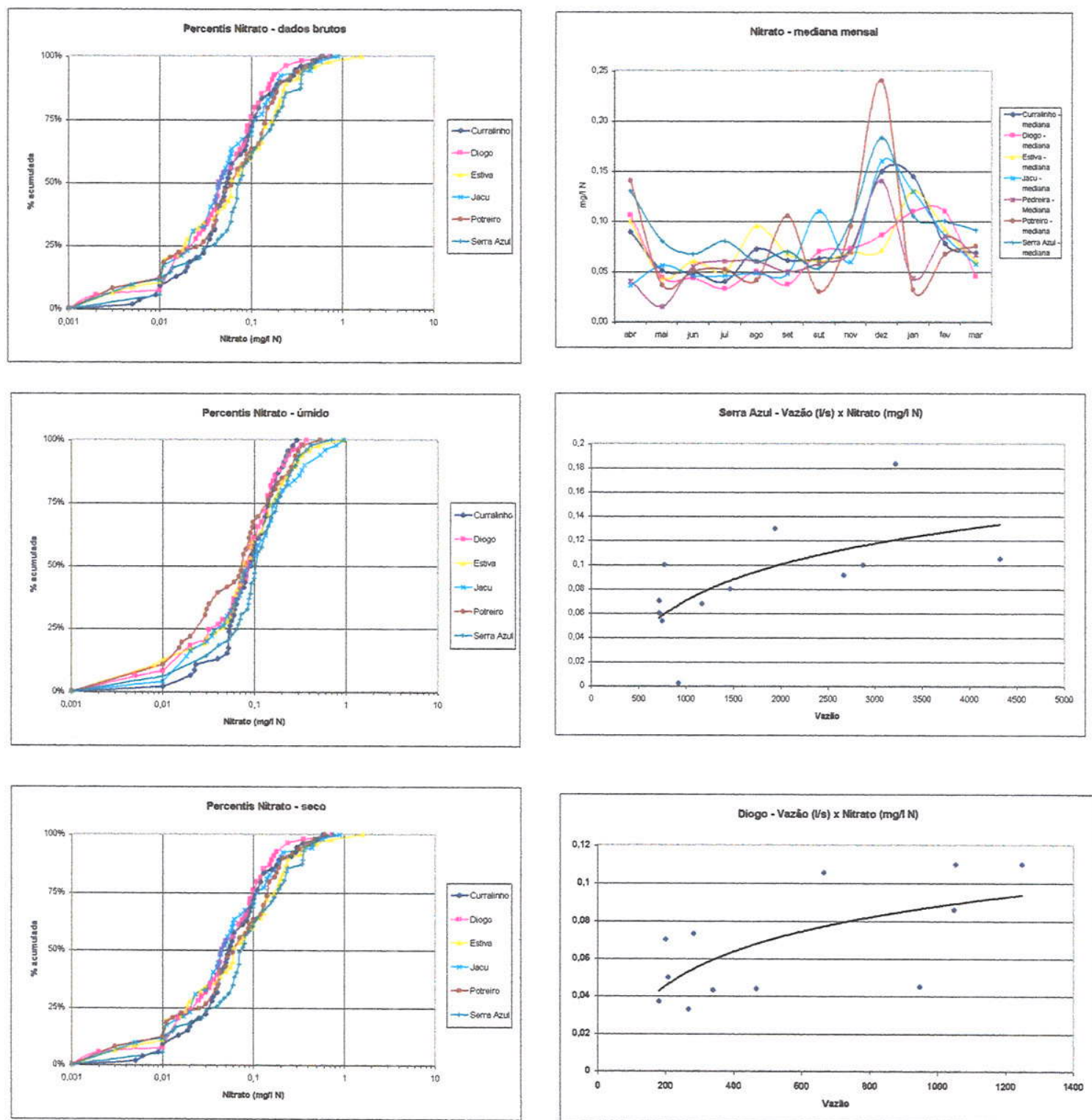

Oliogo - Vazbo (Vs) x Netrato (mol N)

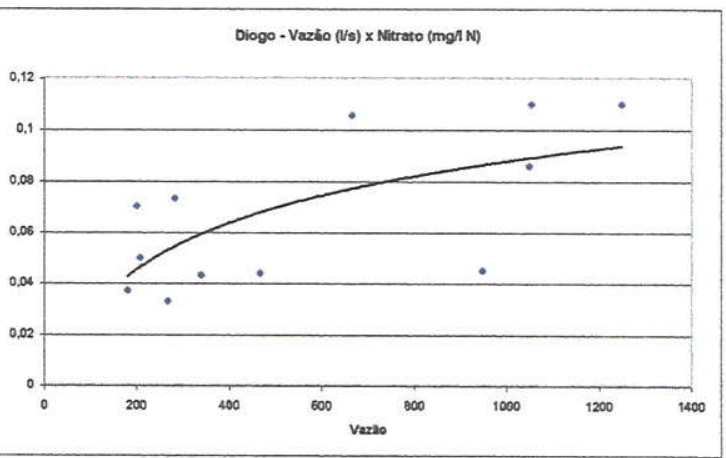


OO (mg) 02 )

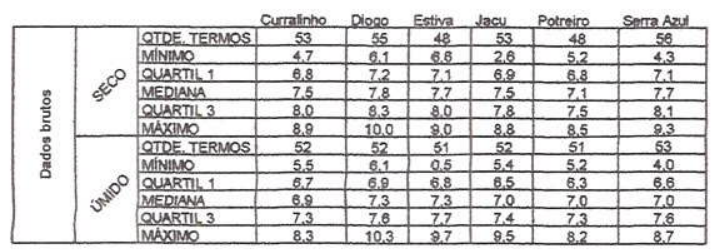

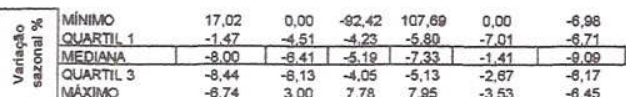

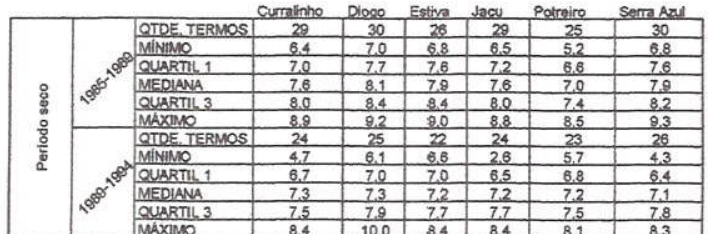

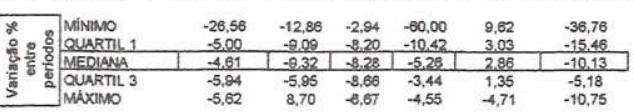

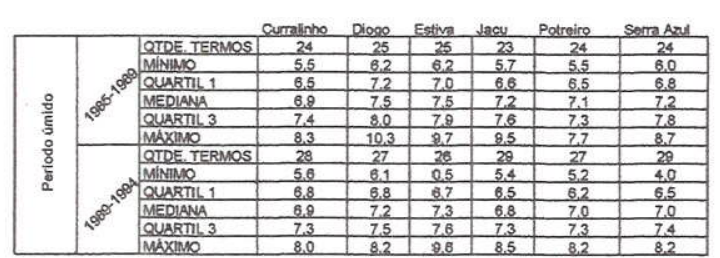

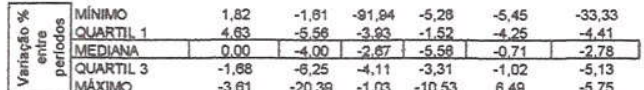

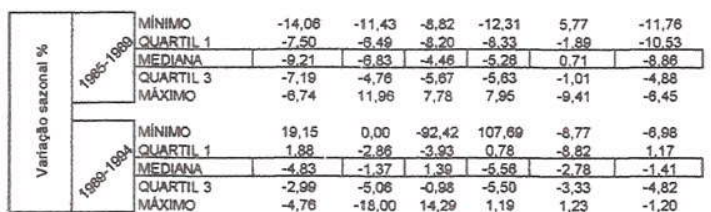
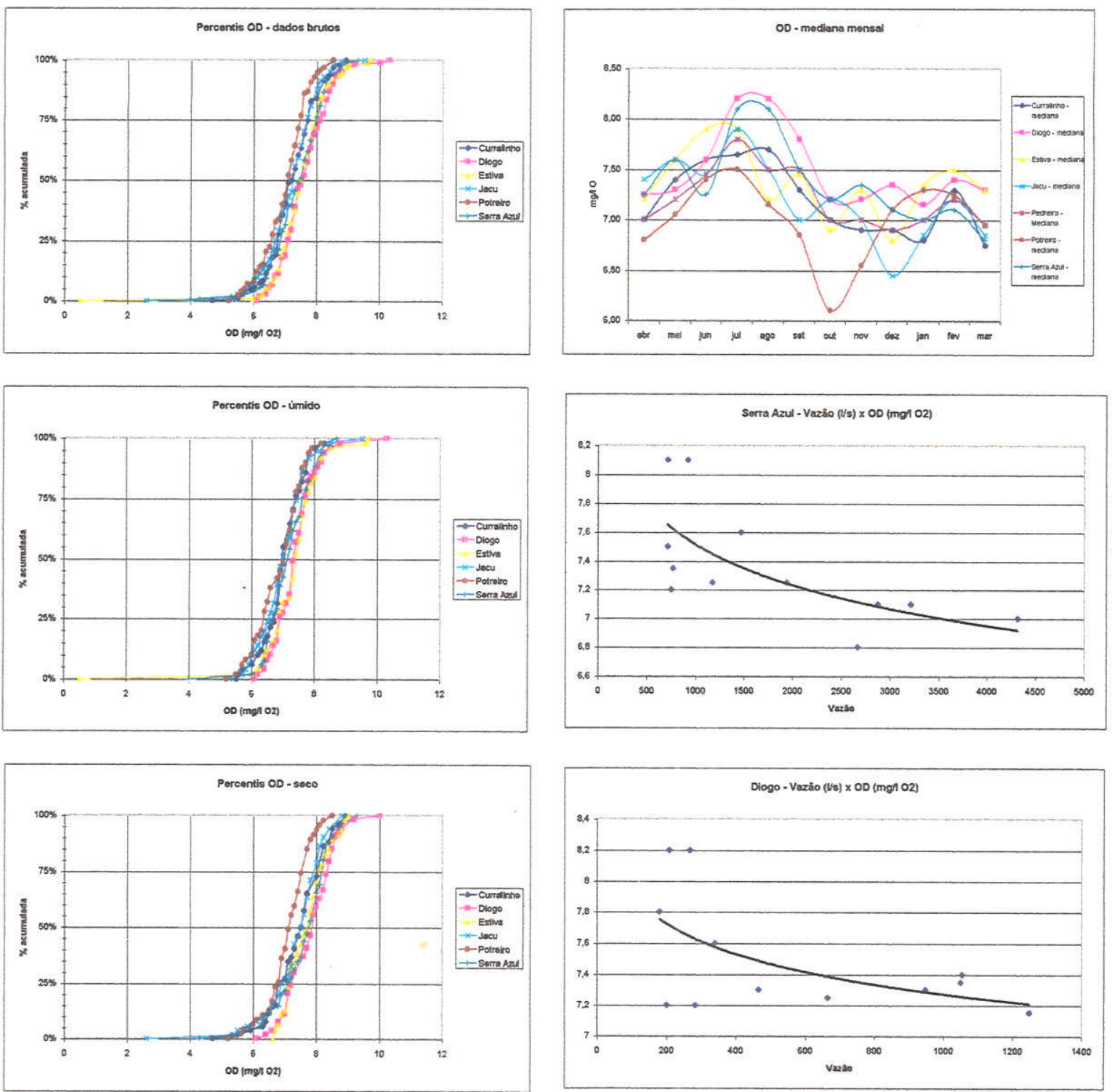





